Portland State University

PDXScholar

1972

\title{
Minority without a champion: the Kanaka contribution to the western United States, 1750-1900
}

Janice K. Duncan

Portland State University

Follow this and additional works at: https://pdxscholar.library.pdx.edu/open_access_etds

Part of the Ethnic Studies Commons, and the United States History Commons Let us know how access to this document benefits you.

\section{Recommended Citation}

Duncan, Janice K., "Minority without a champion: the Kanaka contribution to the western United States, 1750-1900" (1972). Dissertations and Theses. Paper 964.

https://doi.org/10.15760/etd.964

This Thesis is brought to you for free and open access. It has been accepted for inclusion in Dissertations and Theses by an authorized administrator of PDXScholar. Please contact us if we can make this document more accessible: pdxscholar@pdx.edu. 
AN ABSTRACT OF TE weSL of Junce $\mathrm{K}$. Duncan for the Master of Artz in isstery presented March 28, 1972.

Title: Minority Without formon: Whe Waka

Contribution to the Vestern United states, $1.750-1900$.

APPROVED EY WDEERS OP MFE THEIS COMTERE:

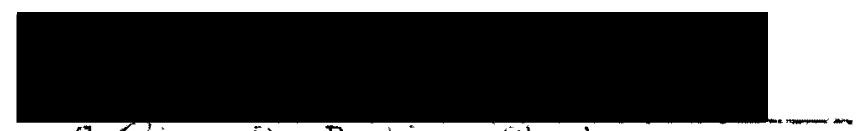

GorponiE. Dodas, Gheirman

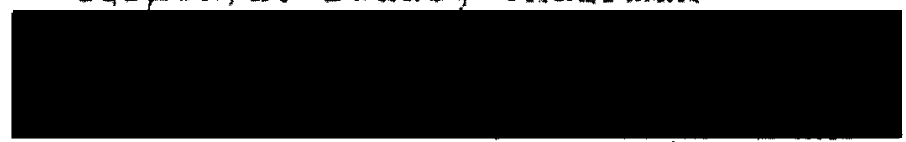

Thomas J. Taughan

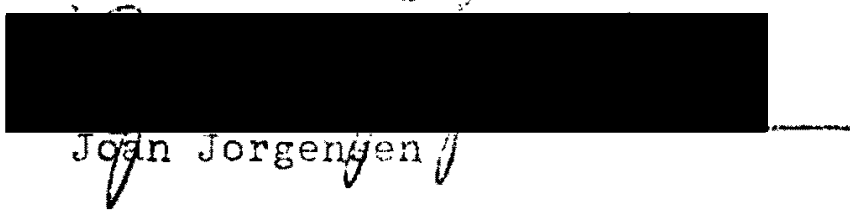

Kanakas, Owhyees, Blue Men, were all nerea nger to loburers from Vawait, or the Sandwich Inknds, wo contributed sienisicostly to the economic, chicusel such

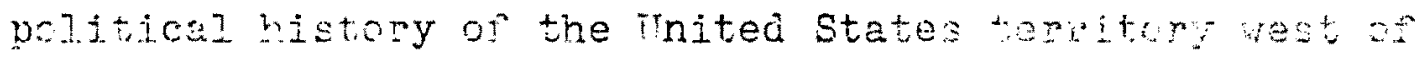
the Mississipot River in the period $1750-190 \%$.

The Bandwich Ishends first enteren the internetional economic scene in the latter ejoteenth centmy when its oxolient ports au fotonebio cinete mede the lesans an

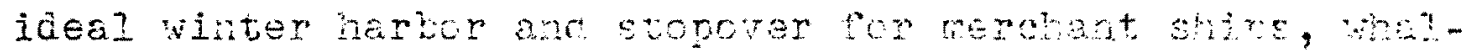
ers, and explorers: resse? who reeded to peplentst rood

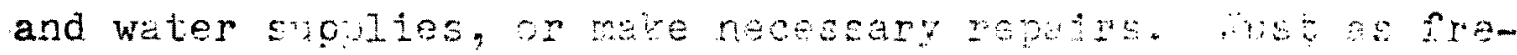

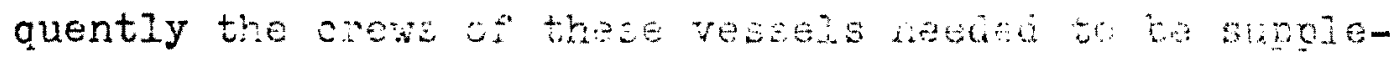

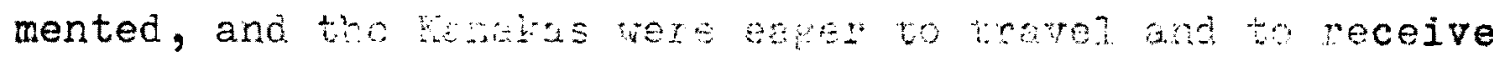


the wages paid to seamen. Kanika seamen sailed with William Douglas, kobert, Gray and George Vancouver; and as seamen and land based laborers for the North West Company, Astor's expedition, the Russian-American Company, Hudson's Bay Company, ano Nathaniel Wyeth's Columbia River Fur and Trading Company.

In 3.834 the first American missionaries arrived in the Northwest and they immediately made demands on the Islanders for labor supply. Both the Nethodists and the ABCFM missionaries hired Kanekas for biliding, kitchen chores, farm labor, blacksmithing, and as herders. When the oregon country began to attract annual. emigrations from the East, the Kanakas found their skills also in demand by these new settlers. They were hired to work in the samilis on as farm and house servants.

Theit seamanship opened doors all over the world for then, and involved the Islancers in varions foreign intrigues. In Japan they were among deserters imprisoned and mistreater by the oriental isolationists. Doring the Americar diviz war many were taken prisoner by Confederate pirate ships. They aiso playeu a role in the moverent to improve the jot of sajors by appearing before the Eritish admiralty cowrts seeking redress for poor treatrent aboara Brilish ships.

Those Kanakes who remained on the American nainiand wanted to become citizens of the united stetes with their white neighbors. Their petstion to the teritoria? 
government of Oregon, however, was refused. Restrictions were placed upon their continued immigration into the Northwest area, they were ignored by the 1.849 Oregon census, the U. S. Consul in California received instructions from the Secretary of State barring the Kanakas from assictance or protection in California ports, and a long verbal battle ensued in the U. S. Congress over exclucing them from the Donation Iand Act.

But the Kanakas were still recognized as excellent seamen and this occupation took them north to kanchatla ard south to California, Mexico, and around the tip of South Averica to ports of the eastern U. S. Those who left the sea worked in California gold fields, preached to Digeer Indiars, became part of the Mormon movement in Utah, or continued to serve the Hudson's Bay Company, Puget's Sound Agricultural Company, and the Russian-American Company.

Throughout their historical journey in western America, they rsmained loyal, inconspicuous, and hardworing. But they also had dark skins and were forejgn in origin. once they threatened white cuperiority and white acquicition of land titles they became the targets of dicerimination. They were not slaves so thay could not be emancipatea, but the white, Protestant ruline hierarchy could not allow them to beccre citizens and thereby pree to settle iand and demano the protection of American laws. They therefore found themselves classed with the Negro, Chinse, and Indiars as undesirable elements in Areriou's "Manjest Destiny". 
By 1900 most Kanakas had chosen to return to their homeland rather than recede into the shadows of American If ${ }^{\prime}$, but their contributions to western America deserve recognition. 
MINORITY WITHOUT A CHAMPION:

THE KAMAKA CCNTRIBTTION TO THE WESTERN

UNITED STATES, $1750-1900$

\author{
by \\ Janice K. Duncan
}

A thesis submitted in partial fulfillment of the requirements for the degree of

\author{
MASTER OF ARTS \\ in \\ HISTORY
}

Portiand State university
1972 
TO THE OFFICE OT GRADUATE STUDIES:

The members of the Committee approve the thesis of Janice K. Duncan presented March 28, 1972.

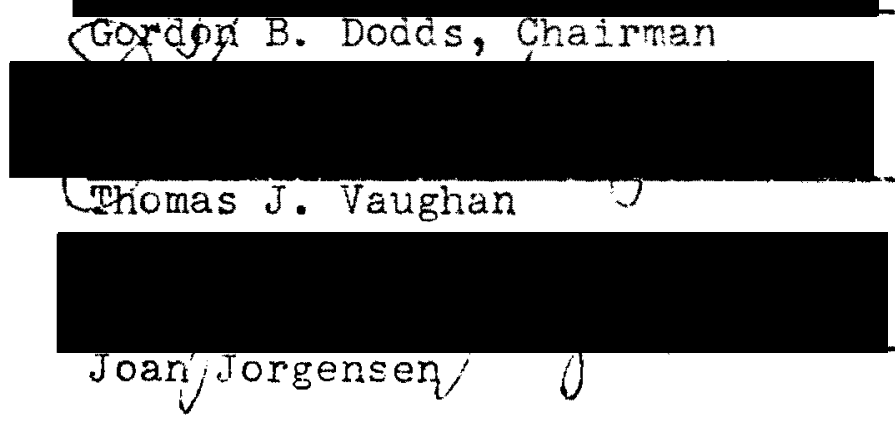

\section{APPROVED:}

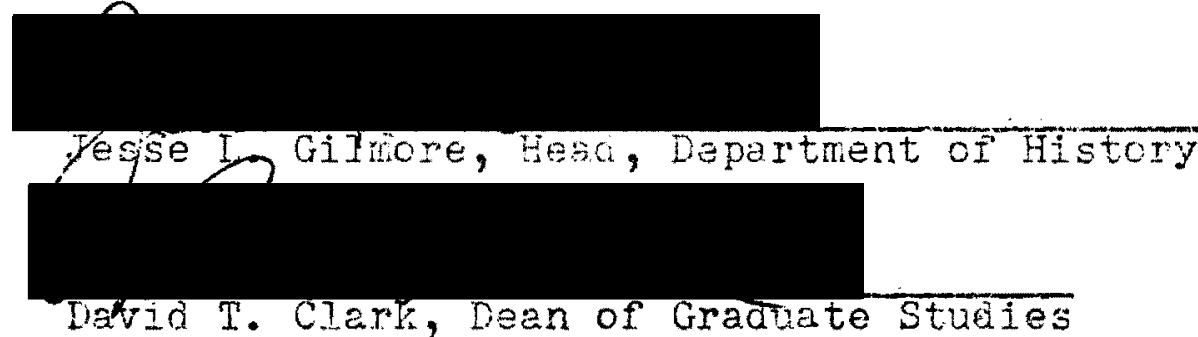

May 5,1972 
TABLE OF CONTENTS

PAGE

CHAPTER

I DISCOVERY AND FXXLOITATION . . . . . . I I

II TFE BEGINNINGS: WORID TRAVETERS

AID FUR COMPANY EMPIOYEES, 1785-1860 • 9

III FOR THE GLORY OF GOD: PROTESTANTS

AHD MORMONS ........... 51

IV NOW SKIIS AND NEN ALVENTURES . • • • • 75

V KAIMAKA COLD EEVER . . . . . . . . . . 98

VI POLIIICAI JEFEAT . . . . . . . . . 1110

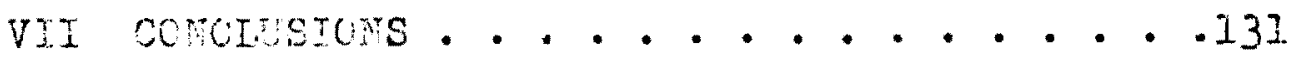

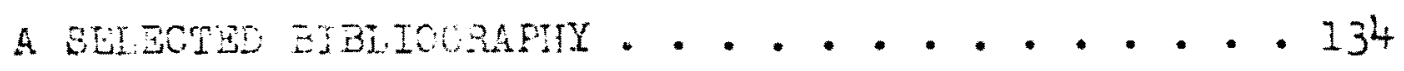




\section{CHAPTER I}

\section{DISCOVERY AND EXPLOITATION}

The lure of the unknown has excited men from time 1mmemorial. The earliest great seafarers of Egypt, Mycenae, Phoenicia, Greece, and Rome sought to widen the known world -- and their own power and influence -- by discovering new peoples, unknown lands, and fresh experiences. A similar restlessness and challenge of exploration survived the fall of the Roman Empire and the demise of the Middle Ages to rise again with the emerging nation-states of the fifteenth century. For these new political entities the adventure and the challenge were augmented by additional considerations: economic independence, sociai recognition, and political prestige.

Thus aid Columbus sail to the west to win social prominence and wealth for himself ano to gain for the span1.sh monarchs a dominant position in Europe that would endure for neaxly a century. ${ }^{2}$ And in response, in the following centuries, the English, the French, tine Dutch, and the

Istaney Fainter, A History of the Midd le Ages $284-$ 1500 (New York: Alfred A. Knopf, 1961), p. 221.

$\hat{A}_{\text {Helen }}$ Mijier Bailey and Abraham P. Nasatir, Iatin America: The Development of Its Civilization (Englewood Clfffe, N.J.: Prentice-Hall, 1960), pp. 10-11; 27. 
Russians made domestic sacrifices to pursue similar conquests or a shorter route to the important trade of China. The French attempted to build their enpire in Canada, the Dutch along the northern Atlantic coast of America, and the Russians in the area of the Bering Sea. The English, too, dispatched colonists to the Atlantic Coast and they continued to support exploration of the Pacific. One of these expeditions was led by Captain James Cook who sailed In December, 1777, to find 1slands at a midpoint in the Pacific to provide fresh water and food for trading vessels enroute to and from China. 3 A year later, his mission accomplished, Cook named his insular discovery after his patron, the Earl of Sandwich.

The Sandwich Islands, now known as Lawail, are located at $18^{\circ} 50^{\prime}$ and $28^{\circ} 15^{\prime}$ north latitude, $1544^{\circ} 0^{\prime}$ and $178^{\circ}$ $15^{\prime}$ west longitude. There are twenty isiands in the archipelago but even now only seven are inhabited: Hawail, Maul, Cahu, Kauai, Molokai, Lanai, and Nishau. The land and the inlana water area comprise 6,424 square miles. Cook described the Islanders as prysicaily strong possessing brown eyes, regular teeth, a skin color that viried from itght olive to darkex shades, and daris, wavy hair. A 3rke Voyeges of Captain James Cook Round the vorla, ( 7 vols.; London: Richard Philijps, 1809), VI, op. 210-11; 231. Hereafter cited as Cook Voysces.

4 Ioid.

John Paxton, 0 . The Btatestan's Yearbook $1970-1971$ (107th ed, New York: Macmilian; 1970), pp.613-15. 
Polynesian people, they inhabited a mountainous land that favored lush vegetation because of a tropical climate and adecuate rainfall. 6 The surrounding waters encouraged the development of fishing and sailine skills by which the majority of the Islanders produced their food.

The culture of the Sandwich Islanders was complex. Politically, the population was divided by a feudalistic system composed of the local chieftains who ruled, the alif, and those who served, the makaajnana. The latter were technically free men but, like European serfs of the Midale Ages, were tied to the land and held no political rights.? As in the manorial system of Europe also, land was leased, not owned, and the occupants were considered vassals of the local chieftain. Both makeainana and alii worshiped natural gods: Kane as creator, ku as god of war, fonc as fertility goddess, ard Kaneloa as ruler of the celestial world. 8 As medieval Europeans prayed to various saints to insure good ercps, so the Islanders worshiped gods of nature to assure gocd fishing or to pacify the feared volcano or the island of Hawai. 9 These then vere the people

6ook royages, pp. 210-2i1; 231.

7 Pal ph S. Kuykendall, The Hawaisan Kinecom 1778-1854: Fourcation and Transtormation fonoludu iniversty of Haxaian Kingdom.

$$
\begin{aligned}
& { }^{8} \text { Ibid., p. } 7 . \\
& { }^{9 \text { Ibic. }}
\end{aligned}
$$


Cook discovered in 1778. They were a primitive but not warlike people who lived by the sea under a monarchical system quite suitable for thelr isolated location.

Captain Cook, their discoverer, was only the first European to penetrate their isolation and he was soon followed by vessels and crews representing France, Spain, Russia, and the United States until by the beginning of the nineteenth century the Sandwich Isjanders had lost their insulated position anc their rulers faced the seeringly impossible task of catapulting forward several centuries: economically; politically, and socially, and their institutions were confronted by those of national states, international maritine laws, and economic patterns tctaliy unintellizible to the Islands' peoples. rhe newcomers abused and ridicuied their gods. Faced with the task of almost Instantaneous adaptability to European law ard governmental structure, international commerce, and Christianity, the Hawaijans were concurrently introdnced to various foreign products and manufactured goods that destroyed their economic base and created severe cultural probiems both in.ternaliy and in their relations with the forejgners.

How was the trancition to be accomplished successfluly" tas it even possible? The answers to these net questions were determined in the traditional manner. From the beginning of history in the Isiands warring chiefs had fought among themselves to acquire prestige and even larger 
numbers of subjects. The introcuction of European weapons and ships macie it possibie for the more crafty to acouire a grezt advantage over their opposition and Kamehameha was the chief who capitalized upon foreign culture and his own leadership capacities to achieve consolidation of the Islands into a single kingdom in 1810 . The beginning $^{10}$ The of a national state was accomplished. After this period of Internal consolidation the new king and his people accepted foreign merchants and the concomitant modern economy they could provice and by 1820 the Islanders also had permitted Protestant missionaries to enter and to teach, and ult mately to destroy the pagan gods. The challenge and adventure and necessity of investigeting the worlo that surrounded the islanas came also to the rewaiians and, as representatives of their king (as the ford Kanake meant in Hawaiian) the Islanders signed on as crewmen aboard the ships that now stopped frecuently at Honolulu or Lahaine to acauire 12

provisions or to winter.

For the most part it was the young Kanakas who began to engage the foreign world on its own terns soon after the beginning of the nineteenth century. Thejr abilities as accomplished seamen made them welcome additions to ships'

10 Ibid., pp. 30-32; 50 .

11 Ibid., p. 100 .

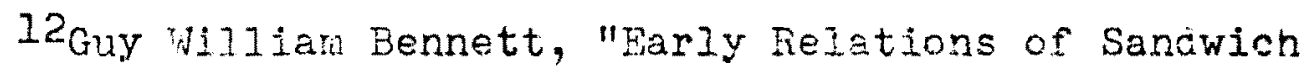
Jslands to Old Oregon Territory," Washington Historical Querterly, IV (April, 1913), 117. Hereafter cited as Eennet, "Early Relations." 
crews and in a short time the Kanakas also had won respect as haroworking and loyal employees. 13

seamen but others went ashore in several areas of the Pacific coast of North America to seek new opportunities and new trades. Kanakas were hired by the Hudson's Bay Company, North Nest Company, American Fur Company, and Pacific Fur. Company. ${ }^{14}$ They acquired the skills of European boatmen, blacksmiths, and soldiers. When the Protestant missionaries arrived in the Pacific Northwest Kanakas became an important labor source, the same role they performed later for American settlers flooding into the region in the $1840^{\prime} \mathrm{s}$. 15

Many Kanakas never fulfilled their duties as reprosentatives of the Hawaiian monarch quite simply because they did not return to the Islands. Some met death bercro it was possible to return, but others relished the new freedom, as well as the monetary rewards, they found along 16

America's Pacific coast. The adventurers who did return, however, brought to their homeland a new outlook and sophistjcation about the modern world in adition to ar

13. Kaye Lamb, ed., The Journal of Gabriel Franchere (Toronto: The Champlain Society, 1969), p. 70. Hereafter cited as Eranchere Journal.

$14^{4}$ see Chapter III.

15 see chapter IV.

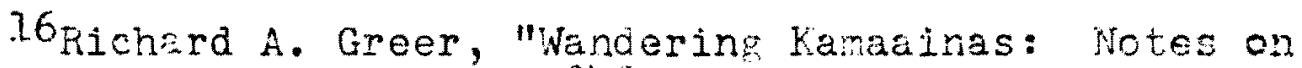
Hawaiian Emigration Eefore 1848," Tonrra] of the Nest, $\mathrm{XI}$ (Apri1, 3.67), 2\%1. Hereatter cited as Creer, "Nandering Kamaaines." 
unfawiliar manner and dress. Their experiences procuced an understanding of the Americans, British, and other nationalities that subsequently proved important to the shaping of Hawailan foreign policy and to the growth of the Island nation.

The numerous Kanakas who delayed their return to the Islands also contributed to the American nation. They formed an important part of the labor force west of the Rockies and helped make possible rapid economic growth in this area during the $1840^{\prime} \mathrm{s}$ and I $50^{\prime} \mathrm{s}$. Although always a minority in numbers, their accomplishments were numerous. They remained docile, hardworking, loyal, but none of these attributes could guarantee thein continued acceptance once the uninhabited West becare propulated with Americans who believed in the superiority of the white race and in the God-given right of white men to acquire all land, claim 211 profits, and control all "inferior," non-white peoples.

The nation to which they had so willingly contributed innaly rejected the Kanaras just as it spurned Indians, Chinese, and legroes. By 1900 most kanakas resident on the moinling hed recognized the futility of seeling homes, security, and equality in the united states and retreated to their komeland where their abilities were respected and where the benefit of their experiences was eagenly sought. In the lshands they helped to buidd a governwent that would 
in time offer security and equality to ali races. ${ }^{17}$ Kanakas might well nave made similar contributions to the development of the American West if the dominant race had accepted them in the nineteenth century as qualified, inteliigent, and desirable citizens.

17E. W. MeGraw to Matthew P. Deady, December 24, 1864. Oregon Historical Society, Deady MS. 48. 
CHAPTER II

THE BEGINHINGS: WORLD TRAVELEKS

AND YUR COMPANY E:PLCYEES, 1785-1860

Once Cook had discovered his Pacific stopover at the Sanowich Islands, it was not long before merchant vessels and whaleships of several countries were putting into the Island harbors. In 1785 the King Georze, captained by Nathaniel Portlock, and the Queen Charlotte, Captain George Dixon, had stopped at the Islands bilefiy for supplies. In the next ten years vessels from England, Lrance, Fussta, and the United States sought the advantages offered by a stop at the Islands for fresh water and provisions. Its climate and harbors also recommended it as a wintering base and Captain Cook was onjy the first to recognize this auditional adisantage.

These first years ont of oblivion also brought the Islend people a new outzet for their ouriosity and for the excelient abilities on the sea. The snis that stopped in the Islerds often were locking for aditiona to their crews, eitier as seamen or as pensonal servants for the officers or for the wives of merchent eaptains who often acompenied

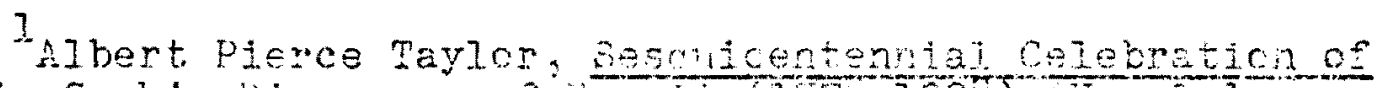
Cactein Cook's Eiscovery of Hewai (1770 Archise of tawait commiston, 1929), p. 31 . 
their husbands. In May, 1787 , the British ship ImperieI Eagle took aboard an liawailan woman, Winee, to be the personal servant of the captain's wife, and she thus became the first recoràed Islander to leave her homeland. 3 In China the captain's wife decided to travel on to Europe and Winee was left behind to return to the Islands. She found passage on the Nootka, then in the China sea, and met an Hawailan chief, Kaiona [Tianna], who had agreed to acconpany John Meares aboard the Noot a when it left the Islanis in August, 1787. There were two other Kanalias who boarded the Nootka with Winee. They "...had been brought to China by different ships, rather as objects of curiosity, than from the better motive of instruction to them, or advantage to commerce." ${ }^{5}$ Meares considered the Islanders intelligent and dignified and described winee as possessing "...virtues that are seldom to be found in the class of her countrywomen to wich she belonged; and a portion of understanding that was not to be expecteo in a rude and uncultivated mind."

${ }^{2}$ Robert C. Schmitt, "Population Characteristics of Hawail, 1778-1850," Hawail Historical Review, I (ApriJ, 1965) 199. Hereafter cited as Schmitt, "Population Characteristics."

$3_{\text {Rajph }}$. Wuyliendall and A. Grove Day, Hawail: A History From Polynesian Kincicn to American State (ingiewood CIifs, Nof.: Frentice-Hal1, 1961), p. 3I.

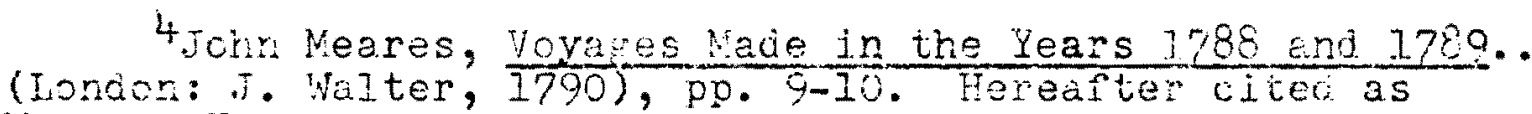
verares, Voyeges.

5rid.

Gournal entry February 5,1788 , ibid. 
Winee fell ill with a fever and Tianna, although a chief, cared for her constantly. Then rianra also became 111 and Meares decided to transfer the Hawalians to James Douglas' Iphigenia since its course was set directly for the Is]ands. Winee died aboard the Iphigenie February 5, 1788, and was buried at sea but Tianna recovered and jeter joined another voyage to Nootka. Sound. Yeares was even hj.gher in his praise of Tianna and consicered him to have the "...capacities which education might have nurtured into intel.lectual superiority..." ${ }^{7}$ once Tianna returned to the Islands this intelligence and the first-hand knowledge of Europear weaponry he had acquired could only have strengthsned convictions already held by the various chieftains that such military technicues were far siperior to their own. Kamehameha shrewdly adapted the European technology, employed its weaponry effectively against his countrymen, and gained control of the Islands in 1810 .

While internal warfare still raged, the number of vessels arrivirg in the Islands increased. After 1788, all the vesseis heaced for the Pacific Northwest coast nade stops there, and several of them took aboard Havaiian men. in 3789 Captain Robert Gray sailed with Chief Attoo who accornanied him all the wey to Boston. He was with Gray

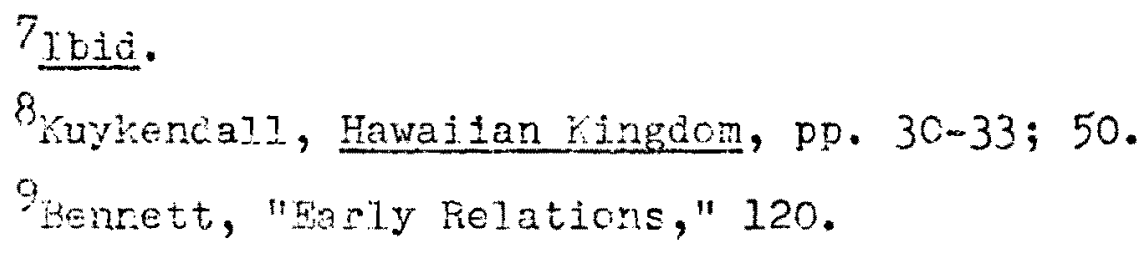

7 Ibid.

Bruykencizl, Hawajian Yingdom, pp. 30-33; 50 . Genrett, "Garly Relations," 120. 
when he discovered the mouth of the Columbia River in 1792.10 That same year the IMS Jenny sailed from the Islands for Nootka Sound with two Hawailan women who later transferred to the Discovery captained by George Vancouver. ${ }^{11}$ They returned with him to the Islands in 1794, at which time Vancouver had his ship carpenters teach the Hawailans how to buili the large European vessels.

Kamehameha I thus took control over the Islands partly through utilizing modern firearms, and then continued to adapt his country and its people to the techrology of the industrializing and mobile world. The early European explozers had returned home with fantastic estimates of the iches to be gained on the coast of the Pacific Northwest through sea otter and whales. This news traveled rapialy and each year after the keginning of the nineteenth century there was an increase in the number of ships that began the jounney from Bostcn or Enzland to the Pacific Northwest. They all stcpped in Tawaii and many needeù additional crew merabers. The Hawiian people, especially the young men, also wished to benefit from this new opportunity and volunteered readily for duty with the merchant vessels.

10 R. C. Clark, "Hawailans in Tarly Oregon," Orezon Historica Qustarly, 35(March, 193t), 25 . Herearter cited as R.C. Clark, "Hawaians in Sarly Oregon."

Il"Menzies' CaIffornia Journal," intro. by Aice Bastwood Califurnia Historical Society Guarterly, II (fandary, $\left.192^{4}\right), 265$.

12 Agnes C. Conraci, "Nawajian Registered Vessels," Hawailan Journal of Histcry, 3 (1969), 31 . 
Two young Hawailians named Hopoo and Oboolitah were among those eager to offer their services. In 1807 they joined the crew of a vessel captained by John Brintnall of New Haven, Connecticut, Hopoo as a cabin boy and Obookiah 13 as a sailor. They landed in New York in 1809 and were taken in by the families of Captain Brintnall and Dr. 0 . Hotchkiss. Hopoo later returned to the sea and served during the war of 1812 before being captured and imprisoned by the British in the West Indies Islands. In $1816 \mathrm{Hopoo}$ returned to New England, found Obookiah, and went with him to Litchfield Farms to study for the ministry. ${ }^{14}$ infortunately, Obookiah died before the two could return to their Islands as ministers, but Hopoo did reach Hawaii again in 1819. The captains too began to ask for the services of Kanakas, or Owhyees, as the Sandwich Isianders came to be called. The term Owhyees was an approximate pronunciation, by English and American standards, of the island of Dahu. Kanaka was originally a Polynesian term for a man of aboriginal blood. It would later become a cierogatory word by those who wished to impress the Hawailans with their

13" "vemotrs of Thomas Hopco," The Hawaitian Icurnal of Memoins," $2(1968), 43,46$. Hereafter cited as "Hopoo

14 Ibiri. 53.

15 Ibid., 53-54. The Friend (Honoluiu), March 5, 1859.

16 Merze Tate, The United States and the Hawajian Kingdon: A Political History (New Haven, Conne: Yale Diversity press, 1965 ), p. $45 n$. 
low position on the status ladder. To the Islanders, however, it meant approximately the same as the English word 17

agent. Thus, the kanaka of Kamehameha was his agent or business associate just as the American Foreign Secretary would be the kanaka of the President of the inited states. In 1811 Jorn Jacob Astor's Tonauin sailed into HonoIulu Harbor on its way to establish a fur post on the Pacific Northwest coast. The Tonquin's captain, Ionathan Thorn, wanted to hire twenty-four of the islanders, twelve as seamen and the remeining half to work at the proposed 18

fur post. Karrehameha was interested in Thorn's proposal, but he also wanted first-hand information about what such a Iucrative business as supplying seamen and laborers to the growing fur trade might involve. The king therefore appointed one of his favorite kanakas, Naukane, to go aboard the Tonauin as a royal observer. Naukane had witnessed the death of Captain Cook and was a member of the royal family that took over power with Kamehameha in 1810. Because Naukane resembled one of the Americans, he becane known as Tohn Coxe and retained the name throughout his long anc colorful life in the Pacific Northwest. 19

17 Tawail: Sandwich Islancis correspondence, British Foreign Office, 1842-74. Oregon Historical Society on bicretilm. Hereafter cited as British Ficreign Office microfidm.

E David rittelson, "John Coxe: Hawail's First soldier of Iortune," Rawajian ilistorical Review, I (January, 1965), 795. Fereacter cited as hittelson, "John Coxe." 10 ibia. 
In February, before the Ionguin left Hawa1i, two Islanders volunteered to dive for some pulleys that had been dropped overboard. Captain Thorn promised to pay four yards of cloth if the Kanakas succeeded in retrleving the pulleys. The Islanders proceeded to demonstrate their abilities as divers and were tined under water for four minutes on one dive. 21 The American crewnen were impressed with the Kanakas as good saizors also and since the Islanders were eager for adventure, more of them could have been engaged for the Facific Fur Company.

Fortunately for Coxe, his position as royal observer did not require him to remain aboara the Tonquin after it reached the North American coast. The ship developed 1ts first problems Narch 24, 1811, on approaching the Columbia River. A small group including Stephen weaks and two Kanakas were sent out in a small boat to make soundings of the river entrance, but an ebbing tide made it impossible for them to return to the Tonauin. 'Weeks and the Kanakas drifted until their boat was swamped whereugon the two Islanoers immediately stripped of their clothes, rifnted the boat, beiled it out, and retrieved the cars. The kanaks then helped Weeks into the boat but it was so cold

$$
\begin{aligned}
& 20 \text { Tranchere Journal, p. } 59 . \\
& 21 \text { Ibid., p. } 59 . \\
& 22_{\text {Ibid., p. } 70 .} \\
& 23 \text { Ibid., po. } 72-74 .
\end{aligned}
$$


that shortiy after midnight one of the Hawaijans died. When the two remaining men reached shore the next day, Weeks aragged the second Kanaka onto the beach but his grier over his companion's death had so affected the secono Kanaka that he refused to go further. Weeks covered him with leaves at the eage of the forest anc left him to die.

On the 25th Thorntor had sent out a search party for the lost seamen. Weeks was soon found arci the next day, 25 March 26, the second Kanaka was discovered stil.] alive. That same day a burial service was held for the dead Islander. The Kanakas dug a deep hole in the sand, placed the body inside, and put in offerings of biscuit, pork and tobacco. After the grave was filjed the Islanders formed a double line facing east, one of them, acting as a priest, sprinkled the others with water, and then a short prayer was said. The ceremony then ended, the men returned to the ship, and the Tonquin continued its way up the Columbia River.

Coxe went ashore with the twelve Kanakas hired as laborers to build Astoria. The Ponouin's contain cecided to do some further exploring and trading with the Indians along the northern coast but he and his crew, including the

${ }^{2}$ Hilo $\mathrm{N}$. Quaife, ed., Adventures of the Pirst Settiers on the Oregen or Columbia piver (Chicago: Iakesiae Press, 19(3), pp. 70-1. Tereafter citeu as puife, Pirst settlers. 25 rroncióre journal, p. 7h. 26 Ibid. . 75 . 
twelve Kanalas hired as seamen for three years' service, soon ran Into ajficulties with the natives that ended in disaster. The natives and Captain Thorn couj not agree on fur prices, the Indians attacked the Tonguin, and all of the men aboard were killed and the vessel sunk.

The remaining Kanakas also were experiencing problems at Astoria. The labor required to build a fort in the wilderness was exhausting, and the Islanders, "...usea to a dry, pure atmosphere, sank under its infuence; damp fogs and sleet were frequent,...," the food also was ba.2 and as a result, half of the work crew usially here down sick. By July, however, the fort was at least livable and on July 22, David stuart and seven others, including John Coxe, set out to establish a. post in the interior. Along the upper Columia stiart's party met that of David Thompson of the North vest Company. 30 Thompson was taken by the humor and wit of coxe, and negotiated to exchange one of his men, a Canraian named Boulard, for the Kanaka. 31 For his paxt, Coxe seemed willing to remain in the new country and did not feel obligated to return to the Islands to report to his

27rayne R. Kime, "hifired Seton's Tournal: A Surace For Irviag's Tonouin Disaster Account" "Pregon Historical. Guanteria, IXXT (December, 1970), 314-15.

$$
\begin{aligned}
& 26 \text { ousife, Pirst Eetters, p. } 81 \text {. } \\
& 29 \text { bid., p. } 111 \text {. } \\
& \text { 3yittelson, "John coxe," } 195 . \\
& 31510,123 \text {. }
\end{aligned}
$$


king. Those makajnana who had contracted themselves as seamen and laborers to the Pacific Fur Company certainly enjoyed the new freedom offered by the Northwest even more than their royal observer.

Coxe joined Thompson and traveled with hior to Fort william on Iake superior. ${ }^{32}$ The Kanakas who rerrined at Astoria welccmed a second Astor ship, the Beaver, on May 12, 33 1812. Ihis ship brought five Canadians, one of whom was Ross Cox, seven Americars, and twelve Kanakas to angmert the employses. Astor's men were having aifliculties competine with the North West Company and the loss of the Tonquin had reduced suppiles. Astor's employees al so were frequently Iured away by better offers from the canacian compary, but the final blow to Astor's ambition came when war broke out between England and the Inited States.

Coxe, as a North Nest Company employee, became involved in an expedition sent to seize Astoria. He sailed with the furce Prom Portsmouth, England, aboard the Esac lodi March 25, I813. After a transfer to the Ha Racocr, Coxe and the other Combany employees reached the Columbia River rovember 30. Sy then, however, the Pacific Fur Company had been solic to the Morth wast Company and nothing was left to seize.

$$
\begin{aligned}
& 32 \text { Ibid., } 195 . \\
& \text { 33Franchère romraj, p. } 114 . \\
& 34 \text { reife, irst Settiers, p. } 395 . \\
& 35 \mathrm{Jbic}, p 0.195-6 .
\end{aligned}
$$


Coxe and the other Kanakas remained et Astoria, renamed Fort George, until August, 1814, when the thirty-two Islanoers who had contracted with the defunct Pacific Fur Company found themselves without jobs and forced to return 36 to their home. Coxe felt cbligated to return with them and enci his function as royal observer. 37 They sailed

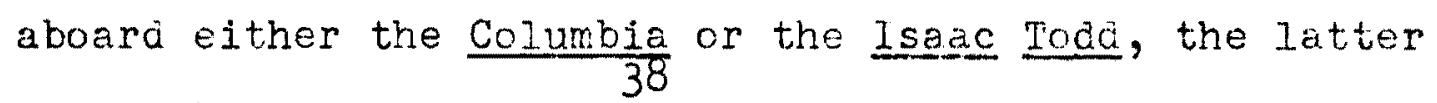
manned by Kanata seamen.

The North West Company, however, had been impressed by their brief experiences with the Is]anders, and it continued to bring them into the Northwest to serve at Fort George and in the interior. Ross Cox, one of the Company clerks who arrived in 1812 , made many entries in his journal on the Kanakas. 39 He considered them far superior to freemen, and "...not wanting in courage, particularly against the Indians, for whom they entertain a very cordial. contempt;..." They were used to augment the crews of the coast trade vessels and to replenish the inaceouate work parties ashore. They were submissive to the Ccmpany employees,

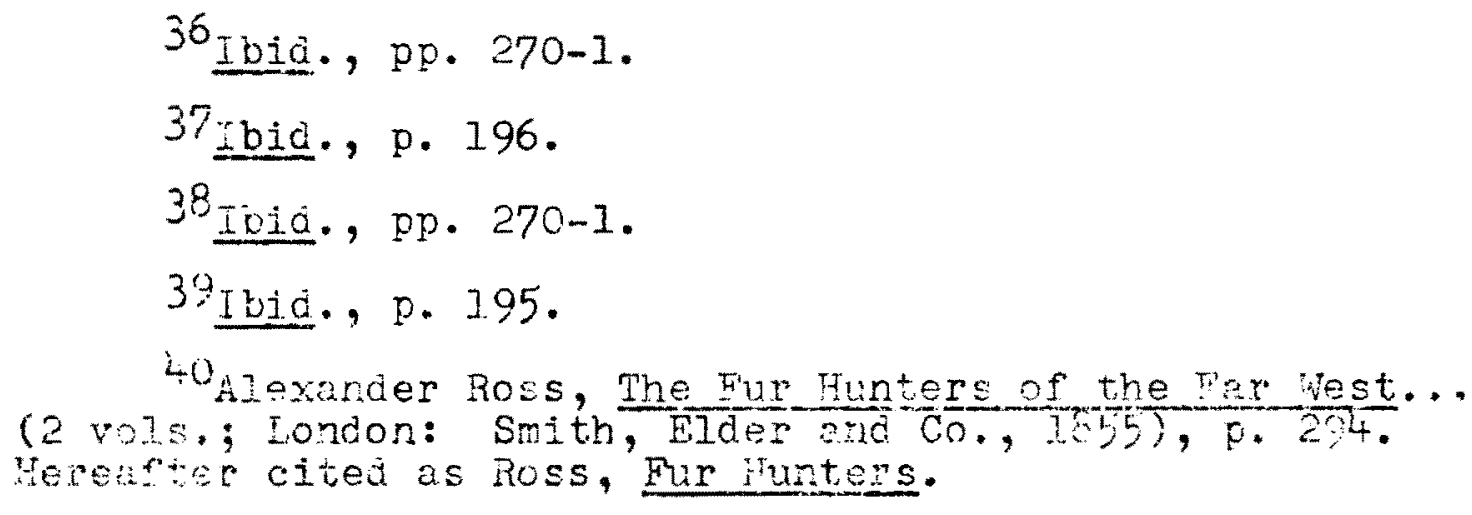


honest, trustworthy, and willing to perform any dities of which they were capabie. As expert swimmers they were invaluable in righting swamped cances and keeping less able erployees from drowning. Ross lauded their industry but did not feol that they were capable of leauership. Since the North West Company hired them for a wage of merely food and clothing, the Kanakas also were cheaper labor than that of the Canadiar voyageurs.

In 1816 the Company's Colone? Al] en arrived at the Columbia. Aboard was a Russian renegade named racot who had been piaced in irons for inciting mutiny. No doubt the captajn of the Colonel Alien warted to rid rimself of this problen sajlor so Jacob was left at Fort George. Ho promptly began preaching desertion to the Kanakas at the fort and one night led eighteen employees, including Kanakas, toward California. The next day an interpreter was sent to cvertake the deserters and when he did he found the Islanders were resdy to abandon the treacherous Jacob. "...the fugitive islancers wheelea about, and, accompanying the internoter, returred again to the establishment on the third day."

$$
\begin{aligned}
& \text { 4igid., p. } 293 . \\
& 46 \text {.0ss, pur runters, p. } 82 . \\
& 43 \text { zidi., p. } 83 \text {. } \\
& \text { بribje., p. } 84 .
\end{aligned}
$$


In Jaruary, 2817 , the North Jest Company ship Columbla returned to Hawail for repains and to cure pork. Her captain had orders "...to bring as many of the Sandwich Islanders to the Columbia River as...could conveniently cbe accomodate $d_{J} . " 45$ The Islanders were still eager to join the fur companies on the American mainiand. Those who had returned from the ill-fated Astoria venture were probably among the first to volunteer. Coxe would have been among them if his king had not had other plans for him. The experienced Kanakas certainly did not return to the Is]ands to conciem laboring for the fur companies or recruits wovd have been difficult to obtain.

When the North West Company estabiished Fort Woliz Wajla in Juil, 1818 , those employees stationed at the post. consisted of twenty-five Canadiane, thirty-two Kanaras, and thirty-ent ironuois under the jeadership of Donald Mac. kenzje. 47 Mackenzie had quarreled with his superiors at Fort leorge cver the amount of supplies ard men he wolid need at the new fort to trace successfully in the interior, bit he ended with the thirty-eight Iroaleis who gave the party troubte aimost from the beginning. These Indians plotted egejnst Makenzie and finaly attacked him one riteht. Te was

45 peter Corney, Voyages in the Worthern Pacifie... (Pon-

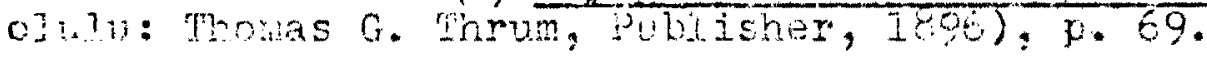

46 iivterson, "rohn coxe," 196.

4 Ross, Fus lunters, p. 178. Fort Naila Walla was 10cated on the ast ban of the Columbia near the mouth of the wale Halla river. 
saved by the arrival of "... some of the Canadians and faithful Owhyhees[sic $\ldots$..."

Mackenzie and his party wintered among the snawe Indians in 1820. Three of his Kanakas had been sent to another area to hunt beaver and when they did not return, Mackenzie sent out a search party which found "...the place where they had been hunting, and where they had been murdered; the skeleton of one of them was found, but nothing else" The river in the area was thereafter known as the Owhyee. Mackenzie and the remainder of his group returned to Fort George to conclude this unsuccessful expedition which Cox attributed to the employment of too many freedren rather than "Good, steady men of character, thrifty and perservering,...no matter to what class or country they nay belong... ${ }^{50}$ Cox was prejudiced against unsatisfactory wcrk.. ers, but not against racial groups.

The North Nest Company had cieveloped other problems and could not concern itself with the quality of its employees or their welfare. For several years the Company anc the Iuason's Bay Company had been fighting to gain control of the fur ewpjre east of the Rocky Mountains and to eliminate the opposing comvany as a competitor. 51 By 1820 the HEC was

48 Ross, Fur Hunters, pp. 158-60. $49_{\text {Ibid. }}, \mathrm{pp} .264-5$. 50 Ipid., pp. 144-5. 51 Ibid. 
encroacining in the Pacific Northwest and at the same time the Aserican whalers were beginning to flood the liorthwest area with ships sailing out of Nantucket, New Bedford, and New London. Both the Americans and the HEC threatened the Indian trade and the Hawaiian labor market proviously under control of the North West Company. Finally, on March 26, 1821, the English government forced a merger of the $\mathrm{HBC}$ and North West companies. 53 Ross Cox was anong the emoloyees who joined the HBC. His experience would be needed if the HBC was to accomplish the task of corsolidating two work forces without losing efficiency, and of defeating the American competition.

The Kanaka labor force was a key factor in the HB: cperation. Ross pointed out the inadvisability of using freedmen and the unreliability of the rroquois and other 54

Indian tribes. The Canadian voyageurs were destrable employees but were also expensive and indeperdent and nany of them were unwliling to leave the Red River Settiement area. The only other source of cheap labor was in the Sardwich Islancis and by 1823,200 Kanakas had left the Islands although many of them were aboard American whalers.

52.jiram Bingham, A Residence of Twenty-cne Years in the Banduich Islands; ... (Hartfora: Hezekj ch Huntington, $\overline{18}(8), \mathrm{p}$. I3t. Herearter cited as Bingham, Residence of Iwenty-one Years.

3Foss, Fur Hunters, p. 278.

54 Ibig., $p .141$.

55 Schnit, "Population Characteristics," 206. 
In fact, they were so of ten employed "...that a reserve of trainec sailors... formed in the islands. "

Obviously, the HBC needed to find ways to attack the labor problem that faced the Chief Factor at Fort Vancouver, Dr. John McLoughlin. He was an astute businessman, as evidenced by a net worth of $\$ 142,585.02$ when he retired, who exerted a powerful influence as chjef factor at Vancouver, as is well known. 57 The first move toward cornerIng the labor marlet in the Jslands came in July, 1824, when Richard Charlton was appoirted consular agent there. Astor had offered the Kanakas rcom and bosrd, clothing and a set amount of merchandise ior their lakcrs. Fo North West Company did not pay tre Tslanders either, but the UEC 60 offered them ten pound per year. Where were other incentlves too, for "Hawailans whe had worked for some years could look forward to a life of wealth and ease on their return home."

${ }^{56}$ Greer, "Wandering Kamaainas," 221.

57 Mcloughlin-Fraser Family parers, 1796-1857. Oregon Fistorical Society, 927 , on microriln.

58 foseph Planta to Richard Charlton, iuly 7, 1824. British Foreign office microfilm.

59 Bennett, "Early Relstions," 121.

$60 \mathrm{R}$. C. Clark, "Hawaitans in Garly eregon," 28.

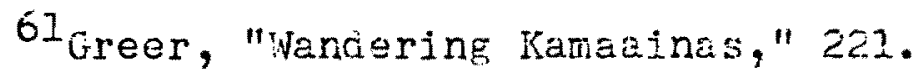


By 1825, 300 Kanalias had left the Islands. ${ }^{62}$ Their exodus coupled with epjdemics of measies and smallpox and the introduction of syphilis by the white men had rapidy reduced the Island population which had been estimated at 300,000 in 1778 but had dropped to 134,750 by 2823 . Kame- $^{63}$ Ka hameha realized the threat facing his people and initiated a poll tax on laborers likely to be lost to the commurity during a long-term foreign employment.

It was also during the period 1823-1825 that hamehameha I visited England to djscuss the future or his Islands with George IV. John Coxe was in this party that salled for England aboard the whaleship L'Aigle. 65 Unfortunately, the king and his wife succumbed to measies before they could meet the British king, but the remaining Kanakas, inclying Coxe, attended an audience with Gecrge IV on september 11, 1824. 66 The bodies or Kamehameha and his queen were returnec to Hawail aboard the Frigate Blonde captained by Lord Byron, cousin of the poet. 67 Coxe no longer was bound by his

62 Schinitt, "Population Characteristics," 205.

63 Ibia.

64 sir George Simpsor, Narrative of a Jonrney Rund the

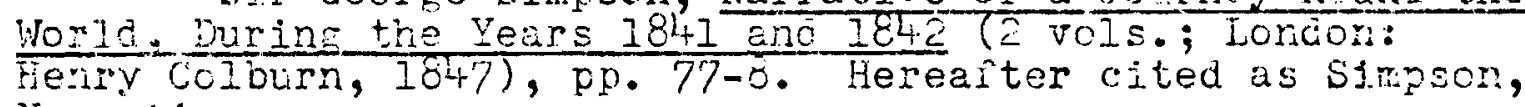
Narjative.

65 Birgham, Resicence of Twenty-cze Years, pp. 202-4, 259. $66_{\text {Ipid. }}$ fiim.

$6 \%$ Letter, July 23, 1824 . British Foreign Office uicro- 
loyalty to the king and he immediately offered his services to the $\mathrm{HBC}$. He was only one of approximately thirty-five working for the Company by 182.5 . 69

The Kanakas were employed in bullding boats, as midalemen on the caroes and York boats, and as seamen on the Company coast vessels. 70 John Work, operating out of Fort George, also employed Islanders and in April, 1825, he was requesting Mcloughlin to furnish more boats, "... manred with whites and Owhyees." ${ }^{71}$ Later that year McLoughlin wrote to the Company's heacquarters in Iondon conplaining that the captain of the Williatn and Ann was late arriving at the Columbia. When the ship dio arrive, the captain kept haif of the Kanakas on board although vicioughIin needed all of them at the fort.

On May 10, 1826, Alexander McLeod, one of the YBC's chief traders, started out on an expecition to trap beaver 68 Kittelson, "John Coxe," 197.

69 John M. Hussey, The History of Fort Vareouver and Lts Fhysica? Structure (Tacoma: Washington State Historicnl Society, [1957?]), pp. 182-84. Hereafter cited as hussey, Pont Vencouver.

70 Burt Brown Farker, Letters of Dr. John Yclouzhlin Written at Fort Vancouver $1929-1332$ iPortland: Enforas \& Kort, 19tb), p. 334. Hereaiter cited as Barker, Mclouglin.

TlJohn Work Journal, entry April 4, 1825. Orezon Historical Society is. 319.

72 Tom McLoughin to Governor, etc, , October 6, 1825 , YoI. IV, Ecioughlin's Furt Vancouver Leters (6 vols; I Ioncon: Tha wuson Bay kecoro Society, 1941). Hereafter cited by HERE 101 . number. 
south of the Columbia. His party included three Kanakas, one of whom was probably Louis Kanota, who would later join John Work's California brigades. 73 the $\mathrm{EBC}$ also used Kanakas to assist in the pacification of local Indian tribes. The first such punitive expedition was led by Mcleod in 1828 against the Clallum Indians. The party consisted of over sixty men includjng Iroquois, Chinooks, and Owhyees. Six Kanakas were aboard the Cadboro which was to support the land party, and two others, Tourawhyheene and Cawinai, manned canoes of the overland force.

It was during this same period that fiort Langyey was established. 75 James MacMillan and Archibald McDcnald were placed in charge of twenty-five men tc build the fort of whom at least two were Kanakas. ${ }^{76}$ The Islanders did all the sawing for the buildings erected, and upon the arrival of the Cadboro in September, 1827, two other Islanders frcm the ship went ashore to help root out tree stumps. 77 then

73 Jonn Work, Fur Brigade to the Bonaventura (San Francisco: Celitornia Historical Society, 1945), p. 103. Hereafter cited as Work, Journal.

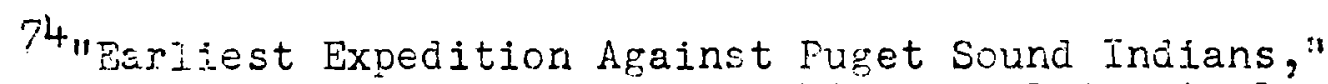
intro. by Eva Emery Dye. Washington Historic3.7 ouarter]. 2 (vanuary, 1907), 1.6, 23.

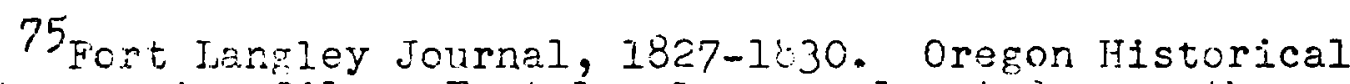
scciety on microfilm. Fort Langley was located near the mouth of the Praser River.

76 I.bid.

77 Entry, September 6,127 , Fort Langley dournal. 
the fort cnclosure was completed the Kanakas began work on the storehouse and other interior builaings, and after their completion they started plowing to prepare for potato planting.

Both McLoughlin and Sir George Simpson recognized the Importance of a sawmill in the Northwest and McLoughlin built the first $4 B C$ sawmill in the region in 1828 which was located five miles upstream from Fort Vancouver and was operated by Kanakas. At first there was only one saw and eight Kanakas to operate it who received wages plus board that consisted largely of smoked salmon and sea biscuit. The timber in the area seened unlimited and production woild not only furnish lumber for the building of ships and forts, but also was in demand in Hawaji. The Hawailan market would help the HBC control the coastal trade, and the building boom in the Islands guaranteed good prices.

By the summer of 1830 Mcloughlin could write to CharIton that 200,000 feet of lumber was being sent to the Islands. In the same letter Mcloughlin requested that

78 Entry, Septerner 10, J027, and january, 1828, Fort Langley Journal.

79 Donala H. Clark, "Samill on the Columbia," The Beaver, Outrit 281 , No I. (June, 1950), 42. Fereafter cited

80 Ibid.

$81_{\text {Ibiaj. }}$

82 HBRE Vol. IV, p. 622-23. 
Chariton, "...by the first vessel or ours consigned to this place which touches at wahoo [sic $]$ next Spring send us fifteen active Owhyhee young men on the same terms as those you procurred for Captain Simpson, - - and optional with us to send them back next fall if we did not require them $[\cdot]^{183}$ The loss of the William and Ann in 1829, which sank at the mouth of the Columbia, was a serious blow to McloughIin and the Company for two reasons: the ship itself was needed if the HBC was to continue its control of the coastal trade; and the loss of the men aboard, including Ranalas, depleted the already inadquate work force. Mcloughlin. informed Iondon that the ship had to be replaced and recommended a complement of twenty-five men and officers "... to which this number might be made up with Sandwicr Islenders by the Captain being instructed to procure them from $\mathrm{r}$. Charlton..." Since the original William and Ann crew rad incliued ten Kanakas, plus another sixteen intended for duty at Fort Vancouver, a new crew of twenty-five would be half Isianders (allowing five for the officers recuested.)

McIoughlin aid not limit his use of Kanakas to Fort Vancouver. In 1831, he wrote Peter skene Ogden at Fort

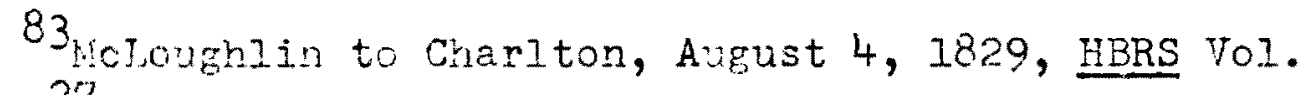
-

81 Holonghrir to Governor, etc., August 5, 1829, HBRS Vol. $1 \mathrm{~V}, \mathrm{pn} .29-38$.

85 Ibia.

86. 
Simpson that he was senuing four Islanders to replace those already at the fort whose annual contract had expired (thus the Kanakas had been at Fort Simpson at least since 1830). Shortly after he wrote his letter to Ogden, Mcloughlin sent two Kanakas to Francj.s Heron at Fort Colvile.

On October 27 and 31, 1831, MeLoughlin again wrote Charlton that another cargo of lumber was being sent to the Islands. At the same time, since the Griffin was conternplated as a purchase to replace the William and Ann, Charlton was requested to sign up a crew for one year with wages of six pounds, six shillings for first mate, four pounis, four shillings for second mate, ana two pounàs, ten shillings for seamen. WcIoughiin wanted Charlton to engage as many as possible. 90

john Work's California brigade in $1831-1832$ employed the Kanake, Louis Kanota, as a scout. Kanota was a favorite of Nork's and was allowed to bring his wife and child on the 91 expeaition. It was also Kanota who had been to Califorria earlier and was therefore familiar with the area. Nork's

87.ncioughitin to P. S. Ogden, Aurust I4, I831. Barker, segergir.

88, Suaghin to Francis Feron, September 9, 2831 . Jbia. Fort Colvile was located on the upper Columbia. Fort Simpscia was lonated near Port Simpson in British Columbia.

89, MaIoynin to Char!ton, october 27, 1831. Ibia. $90_{\text {trig. }}$

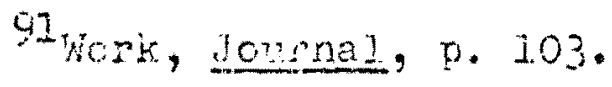


journal contained numerous notations praising Kanota's abllities as a hunter, scout, and retriever of stolen horses. Then in 1832 Mcloughlin discovered $a$ new competitor had arrived in the Northwest. Nathaniel J. Nyeth arrived to establish what he hoped to be a prosperous Columbia River F'ishing and Trading Company. From the beginning, however, Wyeth experienced difficulties in keeping his men from deserting to the HBC. ${ }^{93}$ Wany of those he managed to keep were incapable of managing boats on the Columbia and others were frequent]y down with illnesses. 94 In March, 1832, Nyeth wrote Simpson suggesting that the HBC would find it advantageous to supply Nyeth with the laborers he required. Simpson, however, was more interested in riouing the Northwest of Wyeth and did not intend to cooperate by supplying a labor force. When Wyeth set out for Fort Walla Walla in February, 1833, he had only two men with him.

Wyeth then returned Bast to accumulate additional capital and supplies and to make an agreement with the Rocky Wountain Fur Company to supply their goods at rendezvous

92 Work, tournal, p. 103.

93 Journal entry Noverber 6, 1832. F. G. Young, ed., The Comeswondence anc journals of Cartin wathaniel J. citer as fyeth, Journal.

Sit Journal entry cetober 2tr-25, 1832. Ibid.

95 wyeth to Gecrge Esppson, Rarch 12, 1832, ibjo. 96 Jcurnal entry Febuary 3,1833 , inid. 
the rext fall. Such an arrengement, he felt sure, could be a profitable business arrangement and would make it unnecessary for him to continue his operations completaly on the coast dominated by the HBC. But his experires were mounting, and since he could not contract with the HBC to acquire cheap labor, he was forced to seek men at St. Iouis. There he had to pay wages ranging from 250 per year for a contract of eighteen months to a high of $\$ 300$ per year for a three-year contract.

When weth reached the rendezvous the Rocly kountain Fur Company refused to honor its contract and further made serious efforts to steal away his men, but byeth "...hired enough of theirs to make up, and $r$ didj not fear falling short of troops." 99 "When he started cut for Fort Willa "alla Wyeth had 22 mules and horses, and forty-one employees. Since he remarked on the small wages he paia the new employees, they mist have been Kanakas and/or Indians, or botr. Wyeth's party arrivec at Jalla Nalla September 2 , 101

1834. On the 15th after traveling aorn to vancouver he met his ship, the Mary Dacre, Captain Dar Lambert in chirge.

97 Nyeth to Tucker and Williams, July 1, 1834, ibid. 98 warch 13, 1834 , ibid.

39 ruly 2,1834 , ibid.

100,1 bid.

101 journal entry september 2, $183^{4}$, jbid. 
The captain "...was well and brot csicy me twenty Sandwich Islanders and two Coopers two Smiths and a Clerk." ${ }^{102}$ Wyeth and his new employees started back up the Columbia on cctober 13. On the 26th Wyeth sent out Captain Joseph Ihing, 13 Kanakas, and $\in$ ight whites to reach Fort Hall. Tring's party had all the best horses and when wyeth started out nis four Kanakas had to travel by foot "... for want of Horses and gooas on mjeerably poor animals." 103

Before Wyeth's party had traveled far he learned that all of Thing's Kanakas had deserted him. On November 11 , 1834, weth traveled to Thing's camp and learned that "... the Kanakas had taken about two bales of goods and twelve horses ${ } \cdot]^{104}$ wyeth sent out a search party, geve Thing his four Kanalias and unother ten employees so he could proceed to Frrt HaII, and awaited the outcome of the search. The next day he was notified "...that the Kanakas had not touched the Columia nor passed the Utalla cUmatilla. River and thet filchardson had got a party of Indians to accompany hjm and horses anc hao taken up pursuit on land." 106 Through November until March, 1835 , Wyeth received various informetion on the whereabouts of his deserters. He suspected that much

$$
\begin{aligned}
& 102 \text { Journe] entry Sevtember 15, 1834, ibia. } \\
& \text { 103journal entries October 26, 3. , 134, ibid. } \\
& 104 \text { Journal entry Noverber 1.0-11, } 1834 \text {, ibid. } \\
& 105 \text { Journaj entry rovember } 18,38.34 \text {, 1bia. } \\
& 106 \text { Icurnal entiy november 12, 1834, ioja. }
\end{aligned}
$$


of the information given him by the Indians was merely for the purpose of receiving tobacco, but he recorded each one in his journal. Six Kanalas were reported at the John Day River; later Indians at the Des Chutes said two had stolen Indian horses, shot a chief, and then started down the river. Wyeth hoped this last occurrence was untrue beceuse he did not want to make an exanple of the Kanakas to quiet the Indians; obviously he was unaware of the animosity that existed between the two races.

In February Hyeth heard that of trie runaways "...ten took the trail over the Blue, , one was drowned in crossing some ford $r, j$ one froze in the upper country ${ }^{\prime}, 1$ thet the resioue rafted on the Snake rjver $x$ one more died scmehow about the fallsc, that seven are gone down to Vancouverc. $]^{\prime \prime}$ inen he reached the fort February 12, lyeth found the Xanekas there completely sick of their job so he decided not to troat them severely.

According to the ledgers of Fort Hall, the fanakes were paid $\$ 10$ per month, most of which they spent on clothirg and tobacco. Most of the recovered deserters were returned to fort Wiliam at the nouth of the Mitnomah (Willanette). The runaways were idertiried as Bill King, Lajer, Isasc, Dicl, Charley, George hians, Jack, Harry, Negro, Tom Puiz, Harry Parker, Tonn Pazmer, and Iarry Pickard. The

$$
\begin{aligned}
& \text { 107 Joumal entries noverber } 25,3 x, 1834, \text { 1bid. } \\
& 108 \text { Joural extry pebruary 6, } 1835 \text {, ibid. }
\end{aligned}
$$


total. val.ue of the property they stole was recoried as $\$ 3135.54$. 109

Wyeth's problems did not end with the loss of his Kanakas and in December, 1836, he wrote to the FFC Committee in London informing them he was breaking up his company. He requested the assistance of the $H B C$ in firoing $\approx$ purchaser for the property at the Columbia River, Nalla Walla, and Fort Hall. In a similar letter to McLoughin, Wyeth also asked help in finding means to return his remaining seven Kanakas to their Islanc. "I wiIl further observe that there are more Kanakas to be returned to the Islands than is mentioned..., and that my intention is that they shall all be returned to their homes." 111 Then Wyeth wrote Tring at Fort Hall that he wished the Kanakas returned to their homes, "...unless an arrangement mutually satisfactory can be made to transfer them to the service of the Hudson Bay Company, and it will be proper to write to the American Counsel at caha stating to him the names of those who have diea in the country, ana the ai:posal of the resicue." on January 9, 1837, wyeth received a regly to his letter to the HBC in London. It stated that the HBC wonld purchsee his soods and provide passage to Hawail for the

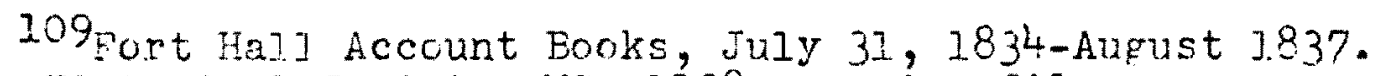
Oregon Historical society, ME. 1198, on microfilm. II0 wyeth to Governor, ete., Decenber 9, 1836, ibid.

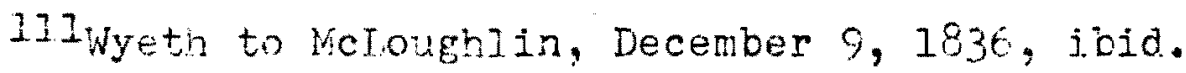
li2wyeth to Thing, December 9; 1836 , ibid. 
Kanakas, Joseph Thing, Abel Baker, and C. W. Walker "... charging a fair and moderate passage money,...." 113 Some of the Islancers, however, did not wish to return to their homes. In a ledger entry for June 18, 1837, Joseph Thing wrote that the Kanakas turned over to the AEC were B1ll King, Dick, Jack Lawler, Charley, and Harry Parker. 114 Rice, Pig, John Bull, and Dido evidently accepted the HBC's passage to Hawaii.

The HBC was once again in complete control of the area west of the Rockies. But its labor supplin in Hawaii was creating problems for the British government that threatered to end his career and leave the HBC in Oregon without an agent to keep McIonghlin supplied with Kanakas. In the first place Charlton was not well liked because of 116 his aristocratic manners. Then in 1837 he was involved in an attempt to keep two Catholic priests on the Islands after Kamehameha II had expelled them. 117 Charlton was subrequently called to England and William Miller was appointed in his absence. The Britieh government was anxious to settle the misunderstancing created by Char.tor's actions and the concurrent short British occupation of the 118 iszands.

113 William Smith, Sec. FBC, to Wyeth, January 9, 1837, itia.

114 Columbia River Tishing \& Trading Company ledger, June 18, 1837. Oregon Historical Soc1ety MS. 938B.

115 Inid. 
Charltor, however, made claims on some Island land supposedly granted to him in 3826 . The land was located near the fort at Honolulu harbor and by 1844 was considered quite valuable with twenty-seven buildings located on it. 119 The British government refused to rule on the dispute and Charlton would not produce the deed so that the Hawaiian governinent could make a decision. ${ }^{120}$ Finally, arbiters were appointed for both sides, John Ricord representing the Hawailan government and R. C. Wyllie as arbiter for Charlton. According to James Hunnewell of Bostcn the deed was either a forgery or else the witnesses involved did not know what they were signing. Hunnewell had lived in the Islands in 1825-6 and felt certain Charlton's claim was a hoax. He suggested that if the British government really wished justice it woula "...transfer Rich. Chariton from the Sandwich Islands to New Holland for the remaincer of his life."

116 Duncan Finlayson to James Hargrave, February 29 , 1836. G. P. Det. Glazzebrook, ed., The Hargrave Correspondence (Toronto: The Champlain Society, 2938), p. 230. 117 Eingham, Residence of Twenty-one Years, p. 507. 118 Alex Simpson to Governor Keiriouanaoa, september 28 , 1842. British Foreign office microfilm.

119 Articies of agreement, March 25, 1844, ibid. 120 Ibja.

121 Ibid. Wilitam Miller to G. P. Juda, March 18, 1844. i22" Fxtract from a letter from Jemes Hunnewell Esruire, of Boston dated 20th April 1846," ibid. 
Neither Hunnewell's opinion nor the Island land system, based on leasing rather than ownership, proved sufficient evidence, however, and Charlton finally was granted title to his claim.

In 1839 Alexander Simpson had been appointed to conduct the HBC business ir the Islands but he also proved to be more interested in fostering his own prosperity. In 1841 George T. Allan replaced him. 125 These disruptions in the Islands did not promote good business with the HBC in the Pacific Northwest but they would have been even more serious except that in 1840 a contract had been sigred with Kamenameha III to supply the HBC sixty adcitional Kanakas for a three-year period. 126 This contract set several specific conditions. First, the exact term of service (three years). Secondly, if any of the Islanders desewter, the Compary would pay twenty dollars. Finally, if any diec, the twenty dollar assessment would not apply. This peralty would apply, however, if at the end of the three-year period those Hawailans wishing to return to the Islands vere not allowed to do so. The contract made no provisions, however, for determining and adjudicating any violations.

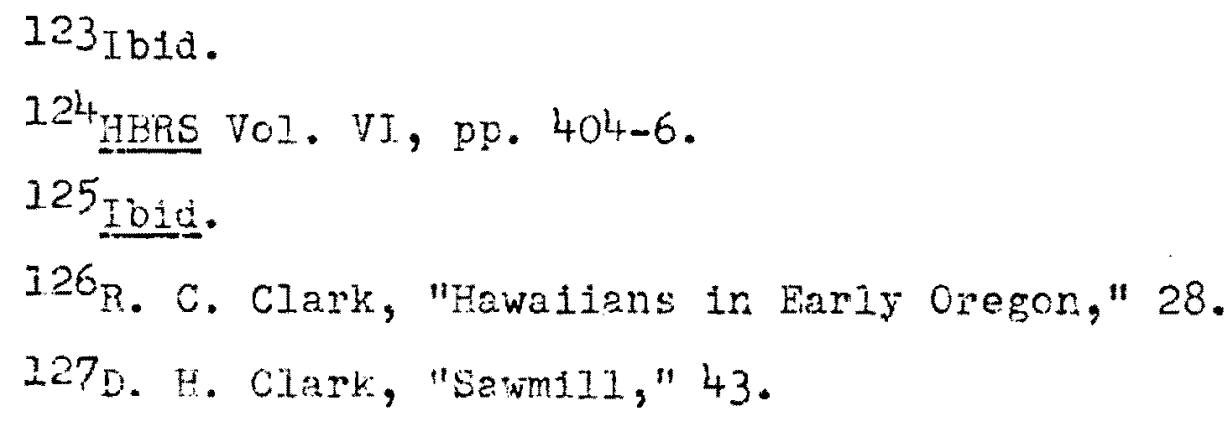


By 1848 the number of Kanakas that had left the Islands had risen to 3,500 and the Island population had dropped to 82,000 , of which almost 2000 were foreigners.

The HBC's total establichment now consisted of sixteen chief factors, twenty-one chief traders, five slirgeons, eightyseven clerks, sixty-seven postmasters, and 1200 permanent servants. There were also 500 voyageurs, and 150 officers and crews of vessels. The governor-in-chief, Sir George Simpson, estimated that at least 3000 were given employment each seacon.

But Simpson had also become convinced that this permanent wor force included tco many Kanakas, a fact which was contributing to the depopulation of Hawai. On March 1, $184 \hat{c}$, he wrote McLoughin that no more should be hireci. This letter was sent from Honolulu where Simpson had stcpped briefly during his journey around the world. Signisicantiy, it was here also that he recorded what he considered to be the reasons for the severe decline in the Hawailan population. Mirst, was "...a spirit, or at least a practice, of emtgration amore the men,..." and the secona cause was the 131 depravity of the women. Ie estimated thet 1000 Kanakas

128 Kittelson, "john Coxe," 196.

129 Te:timony of Sir George Simpson, February 26, 1857, Select Commititee on the Hudson's Bay Company, Parliament, House of Commons, 1857.

130 Simpson to Meloughlin, March 1, 184.2. HBRS Vol. VI, r. 271 .

131simpson, Naxpytive, pp. 14 i5. 
left the Islands annually, going to Califorria, Oregon, or aboard whaling vessels "...a conslierabje portion... saiu to be permanently lost to their country, either dying curing their engagements, or settling in other parts of the world." McLoughlin did not agree with his superior that no more Konalias should be hired, especially since his men were still requesting replacements. He therefore wrote to London stating that he had found it "...necessary to order fifty Sandwich Islanders from Noahoo by the Cclumbia, this number will barely, if it does, replace the retiring Servants next year, and the other Vacancies in the Department, cavsed by deaths, and the Sanowich Islanders, who have been sent by the Vancouver and Columbia this fall to Woahoo, say fourteen." Since McLoughtin had no authority to disregard the orders of simpson, he considered the need for additional Kanakas of such importance that he was willing to risk severe censure for his actions hoping that the HBC Council wonld realize their necessity and condone his disobedience.

McLo:aghlin and Simpson soon clashed again, however, this time over a killing at Ecrt ctikine that resulted in the death of John Meloughlin, Ir. The subsequent investigetion was carried out by Simpson who reported that he had heard testimony that Mcloughlin's son had ordered two Kanakas at the fort to shoot a voyageur nared Heronx. ${ }^{134}$ The

\section{2 ibid.}

133 Actoughlin to Governor, etc., Docember 4,1843 . HERS TOI. VI, p. 182. 
Kanakas did not shoot Heroux but later that same night Heroux turned on Mcloughlin, Jr., and shot him. Two Kanakas were reported to have witnessed the killing, "Captain Cole (a Sandwich IsIander who saw Heroux stand with his foot on $\mathrm{Mc}$ Joughlin's s neck writhing in the agonies of death), and Kalepe (another...Islander who saw Heroux fire the fatal. shot and heara r.Mcloughlin, fall),..." ${ }^{135}$ Further testimony by Thomas McPherson suggested that all of the men at the fort except an Islander named Pouhow had signed an agreement to murder Mcloughlin. 136

There were eleven Kanakas and an equal number of Canaclans and Iroquois at Stikine. ${ }^{137}$ Such a large conspirzcy against one man does not seem plausible from examination of the tastimuny. If everyone at the fort was, indeed, in.. volved it would have been much simpler to tell simpson tre murder was perpetrated by unknown Indians not connected with the fort. It is more likely that the Kanakas, who had no ability in English or French, did not realize what was being planned. When they testified before simpson, through an interpreter from the Cowlitz, they related what they had seen, accusing only the man that had actually ired the

$13^{4}$ weLoughlin to Governor, etc., Noverber $10,2844$. FBRE, VOI. VI, pp. 6-7.

135 November 20,1844 , ibia., p. 19.

136 ivly 7,2842 , 1bid., p. 161.

237 Mctourhitin to John Fraser, Apri1 12, 1843. Neloughlin-Fraser Farily uicrotim. 
fatal shot, and proving once again their loyalty to the one in authority.

In fact, Simpson informed Loncion that he was satisfied that the testimony of Cole and Kalepe "...was meant to be correct," 139 and he also felt the fault was Mclougrilin's for not enforcing discipline and for orinking too heavily. Simpson had the Canadians an Iroquols jailed and sent Heroux to sitka for trial by the Russians because Stline was located in Russian Territory. ${ }^{141}$ Dr. Mcloughlin was furicus over Simpson's conclusions and completely convinced that his findings were incorrect. He went so far as to send his own interpreter, Jilliam spencer, to stikine aboard the Cadboro to question the Kanakas involved. 142 McLoughlin was faced with problems closer to home, however, and the murder of his son was deliberated in Iondon for some time. Although it was eventually settled without denigrating the character of Mcloughlin's son, he and Simpson had reached almost total estrangement over the investigation and never again reconciled their differences. 143

138 Sir George Simpson to Governox, etc., Jinuery 5, 1843. IERE, VOI. VI, D. 349.

139 IDid.

140 Mcloughl in to Governor, etc., June 24,1842 . IBBS Vo]. II, p. 45 .

$I^{\text {th }}$ Mcioughin-Fraser Family microfilm, ibid.

342 acoughlin to Governor, etc., June 24,1842 . HBRS $7 \mathrm{cl} . \mathrm{j}, \mathrm{p} \cdot 45$.

143 ibia. 
The problems facing KcLoughlin at Fort Vancouver were created to a large extent by the arrival of American misslonaries, followed shortly after by increasing numbers of settlers from east of the Mississippi River. McLoughin knew, perhaps instinctively, that these frontiersmen who threatened the HBC power in the Northwest could not be starved out or bought off. But if he assisted them in any way, Mcloughlin would once again be disobeying orders -from Simpson and from London. Yet Mcloughlin did disregard the directives from London on many occasions; the first time was in Noveniber, 1839, when he wrote George Pelly at the Islanỏs asking him to engage "...one single cKanakä with a married man and his wife for Mr. E. Young, charging all expences to $[$ Young's 3 accounts and providing them a passage. ..." $^{144}$

But the Company remained determined to keep the Americans out of the Northwest. One of the obvions ways was to maintain loyalty of the HBC's servants by keeping them content so they would not be tempted by offers from the Americans to wor! for them -- and labor would be a necessity for the new settiers. In former years, the HBC had proved quite successful in capturing the employess of its competitors and now it must find a way to retain the loyalty of its own labor force.

14t wolouchin to George Peliy, November 11, 1939. HBC

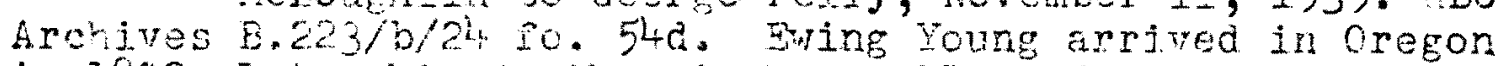
in 2839 ; Iater niz ceath and the problem of his estate lea to efforis loward local government organjation. 
In July, 1844, MicLoughlin wrote to the HBC agents in Hawaii requesting them to send hin a Ioyal, educated Kanaka to be employed at Vancouver for the purpose of preaching to his fellow Islanders and servine as their leader. Later that year Kanaka William arrived in the Northwest. 145 James Douglas considered him well qualified for the tasks at hand, except for nis lack of English. By 1848 Kanaka WiIliam had twenty to forty regular Hawaiians at Suncay services. Fe vas given a private dwelling by the Compariy, and a building within the stockade, formerly the chaplain's schoolhouse and kitchen, was remodeled for the kanaka church. It was fifty feet by twenty-five feet in dimensions, but probably was destroyed before 1858 . 147

The immeciate Comoany territory surrounding Pancouver covered 457 acres which including Kanaka Village, cocupted by servents of the $4 B C, 148$ counted sixty to seventy-five buildings, some of them arranged neatly along the road that led from the wharf to the Catholic church. The builuing styles jncluced American framed, edged slabs, or hewr logs. Most of them were only one story but many had ceilings and 145 Hussey, Fort Vancouver, introduction. $146_{\text {Ibid. }}$ 147 Ibia.

148 Henry J. Narre and M. Vavosour to sec. or State for the Colonies, October 26, 1845 . Oregon Hjstorical Society MS. $\%$, on microfilm. Hereafter cited as M. $4 \%$ 149 Hussey, Port Tencourer, pp. 216-20. 
were either papered or plastered. ${ }^{150}$ Although Kanaka Village also included Indians, half-breeds, and whites, each group living on its own street, the name no doubt indicated a greater longevity or fondness attached to the Hawaiian servants who resided there. 151 There were "...from 300 to 400 [Kanakas 3 employed on the Columbia River, in the service and vessels of the Hon. Hudson's Bay Co. on that coast." 152 and they were still being hired for three-year periocs at wages of $\$ 10$ per month. 153

The HBC decided upon a further method to strengthen the Company's position in the Northwest. In 1839 the Puget's Sound Agricultural Company was formed to contribute to the self-sufficiency of the $H B C$ and to hold land that otherwise might be preempted by the increasing numbers of Americans flooding into the area. The PSAC was ostensibly a sepirate corpcration but its laborers, leaders, end areas of cuitivation were supplied through the $\mathrm{HBC}$.

By 1845 , it was estimated that western Oregon was inharited by some 6000 persons, of which at least 1000 were British subjects. Vany of these were employed as fermers

150 Ibid.

151 Ibid.

152 The Friend, september $4,1844$.

153 Ibia.

154hre and vevosour to sec. of state, October 26 , $18 \div 5, \mathrm{MS}, 47$. 
or herders near Vancouver and at Fort George or Cowlitz Farm. In the vicinity of Vancouver 1200 acres were under cultivation and grazing was provided for 2000 sheep, 1300 cattle, and 700 to 800 horses. 155 Including improved breeds of hogs and couthtown, Leicester, and Merino sheep. The chief swineherd at Vancouver was none other than John Coxe, still in the Northwest and still loyal to his Company employer, of whom Mcloughin in thought so much that the grazing land below Vancouver was known as CoxEliheh, or Coxland. 156

Kanakas also labored at Fort George and Cowlitz, and at Fort Boise fourteen Islanders were employed unüer Jares Craigie, the trader in command there. 157 Kanalas also were located at Nisqually, Colville Town, and the San Juan Is158

lands. At Fort George, Alexander lattie kept a daily journal of his labors and those of the Kanakas in his cherge. They cleaned house, brought in firewood, worked in the gardens and stores. one could sew and another made repairs on the cances; others herded the livestock and tracled oown those who strayed because there were no fences. Only when

\section{I55 Ibid.}

156. . F. Tolmie to M. P. Deady, June 12, 1876 , WS. 48. I57"fort Bojse: From Imperial Outpost. to Historic Site," taho Yestexdeys, 6(spring, 1962), 36. Hereafter cited as 1506. H. Bagley, "Barly Iife on Vancouver Island," orece $3 i s c r i c a l$ Scciety, MS. 101 on microfilm. Hereafter cted as 19.101. 
his Kanakas were already busy would lattie employ natives. On llay 1.1, 1840, one of the Islanciers assisted Lattie in surveying ana marking a claim for Feter skene ogden and the two then forcea a Negro squatter to leave.

Cowlitz Farm cultivated 1000 acres of wheat, oats, 162 barley, and potatoes. It also had a dairy and horse park. The Kanakas at Cowlitz put up fences, repaired salmon barrels, built a stable and house, split rails for sheep pens, and worked in the fields. 163 They were even willing to work on holidays which was considered to be "... much to their credit." $^{164}$ on March 23, 1849, one of them, Kaloma, went to Fort Miscually ir exchange for a French-Canadian, another indication of the demand for Kanaka laborers. 165

The laborers at Cowlitz received from severteen to 166 twerty-seven $z$ in salary. In $1847-48$ nine Kanakas were enployed anc ten others, mostly French-Canadians. A year later oniy seven French-Canaians were at Cowlitz although the number of Kanakas remained the same. In 1849-50 five Islanders vere employed: Honoinlu, Hooiapa, Jomano, Kamaka,

159 Alexander lattie, Port George Journal, Feb. 25-JuIy 25, 1845. Cregon Historical. Socjety ME. 540 on microrilm.

160 Ibid.

16I-ibia.

162-Gimpson, Nerrative; p. 178.

163priscil1: Knuth and Thomas Vaughan, ed., "The Round "and of George 5 . Boberts, the Cowlitz Farm Journal, 1847-5. ." creser fieterjed gartariy, iKIII (une, sept., 1962), $117,120$. 204 13id., $15 \%$. 
and Mowee. Six Prench-Canadisns worked at Cowitz wuring the latter year. 167

In 1849 the Rev. Samuel C. Lamon, editor of Fonoluiu's Friend newspaper and minister in fiawail for the Seamen's Friena scciety, visited the Northwest coast. At Vancover he visited with the Karakas employed there, and expressed gratification that the HBC was peyin the salary of an fawailan minister and school. teacher, Kanaka william. Te also talked to "...an olc Kanaka who had been nearly forty years in the comoany's service, during which period he ha visited England." 169 This was John Coye who hac orifiraliy left the Isiancis aboard the Tonouin.

Damon's visit coincided with the year that many HEC employees deserted for the California gold mines, the year that kmerican emisraticn reached a new peal, and the year that the wited states law officially reached the new oregon Territory. The inplications of these developments were important to the HEC and its servents. The Company was, in fact, on the decline south of $40^{\circ}$ and wchla soon be forced to absnoon many of its posts, including rort Boise. ${ }^{170}$ In

$$
\begin{aligned}
& 165 \underline{\mathrm{bia} .}, 768 . \\
& 166 \text { comitz ram Empioyee lists. Orepon Historical }
\end{aligned}
$$
600isty 35.

$$
167.6 \div 6
$$

$1686 m a 1$ C. Damon, "our Iog.-Bcol." Oregon Historical scoioty Me. 80j. Wereater cited as Ms. 803.

$$
1691010 .
$$


1855 the United States and the Sandwich Islands concluded a treaty proviajing for U. S. goods to enter the Islands duty free, ar agreement that threatered the HBC trade to the Islancis since the company did not have similar privileges. Ey 1859 the FBC had termineted its lawaitan affairs and a year Jater the U. S. Army began cestruction of Kanara Village to provide an area for drilling a light artillery battery. Even Kanaka William was forced to vacate his home and watch it be destroyed. 173

The era of the Hucon's Bay Company south of the fortyninth parajlel hed ended but its Kanake employees dia not depart with the other Company servants. The IISC had failod in keeping out the Americans, ano these new settlers were eager to avail themselves of a well trained and civersified labor force. Such a force was arailabie for by this time an estimated 4,000 Kanakas had left the Islancis, a migration representing $12 \%$ of the Fawaiian males over 18 resiring in Iawail where the total population had declined to $84,265$. The Kanaias willingly remained in the Northwest to be sought

170 weort Bojse," $3 \%$

171 Lord CIarenden to Wijiam Killer, December 31, 1855. Eritist Foreign office nicroriin.

172 pichard W. Van Alystyre, "Interrational Rivalries in the Pacific Northwest," Cregon Histrmical fuarterly, XXXXI (September, 1945), 210. Hussey, Hort Tanconver, pj. $107-8$.

173 unssey, ibid.

174 Solmitt, "population Characteristics," 206. 
by new employers, or traveied into areas of the Nest to seek new experiences and adaitional skilled trades. 
CHAPTER III

FOR THE GLORY OF GOD: PROTESTANTS

AND MORMONS

During the early nineteenth century when the North West Company and $H B C$ were struggling for supremacy on the northern American continent, their major concern was to achieve domination of the fur trade and to attain the greatest possible profit. Such motives did not lend themselves to concern for the welfare of their employees who were victims of this contest. I,iquor was used in large guantities to foster trade ana, in the process, to ease the discomforts of the traders. Equipment and clothing allowances were nigfardly--one blanket, one shirt and a pair of trousers. Their food was mainly hulled Indian corn and melted fat. Religion was completely ignored because it woula interfere with the ovest for profits-- ${ }_{4}$ day of rest taking away twentyfour hours from the fur hunt.

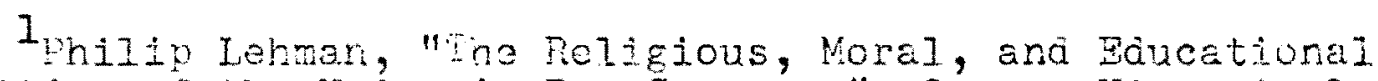
Activities of the Hucecn'" Eay Company." Oregon Historical Suciety Ms. 729. Texefter cited as MS. 729.

Corcon Javidson, The North Nest Company (Berkeley: Tniversity of Califorria Pross, 1918), D. 230.

3 Iojd.

HMs. 729. 
It was after the merger in 1827 that the first Protestant missionaries were sent out, and by 1823 the first church had been established at Red River Sett]ement. New company rules were establiched for religious ixprovenert of employees, and wage scales were promulgated. Sunday was to be observed at all posts with religious services at which all employees and their families were urged to attend. Women and children were to be assigned "virtuous" tasks during the week ano a father was expected to devote time to the education of his family.

In May, 1836, Mcloughlin and the employees of Fort Vancolver received their first religious instructor, Herbert Beaver, who had been selected by Sir George Simpson to represent the Church of England in the Northwest. Beaver's appointrent represented another clash between simpson and Mcloughlin, who had been trying to obtain a Catholic priest for his post since most of the employees were of that faith. Beaver was not only a clergyman but also an English aristocrat who locked clown upon members of the merchant class, including Moloughlin. Both Beaver and his wife considered the Indiens "...rasty and dirty", and all HEC employees

5 Ibid.

Tohn McIeod, Journals and Correspondence from 1812 to 1844.070 . Typeript from originals at Dominion Government

? Seject Committee on the Fuason's Bay Company, Parliament, Fiouse of Commons, D. 368 . 
"...ignorant and unruly...." ${ }^{10}$ He complained of the number of slaves owned by the Company men, but kept a body servant in his own household. He objected strongly to the behavior of the employees and use of liquor in the Indian trade but was continually overdrawing his own liquor allowance. In fact, both Beaver and his wife were fond of their wines. Willjam C. McKay, one of the H.BC employees, called Beaver "...overbearing, dictatorial, hanty, and Proud...." He and McLoughlin clashed from the beginning since neither wished to relinquish authority. McLoughin was Catholic and refused to submit to Beaver's demands that his mitriage be 14

legitimatized by a Protestant clergyman. Beaver retaliated by verbally attacking Yrs. McLoughlin and by sening a long report to the Aborigines' Protection Society of Iondon in which he indicted the treatment given FBC emploveos, including the Kanakas.

In this report Beaver stated that the Kanakas were little better than slaves and were frecuently flogged or imprisoned. $^{15}$ He cited an instance in which a Kanaka.

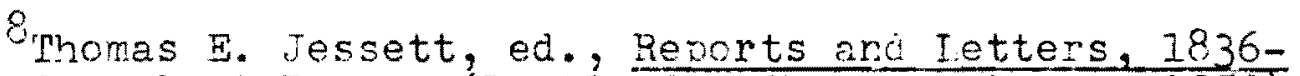
1833, of Jerbert Beaver (Portiand: Champoes Press, 1959), p. xvi. Herealter cited as Beaver Letters.

9 Ibid.

10 William C. Mck to Col. Thonas M. Anderson, iuly 17, 1891. Cregon Historical Society, MS. 495. Hereatter cited as MS. 495 .

$$
\begin{aligned}
& 11 \text { Beever letters, p. } 140 \text {. } \\
& 12_{\text {Mokay to Anderson, ibia. }} \\
& 13 \text { Ibid. }
\end{aligned}
$$


"...was confined in irons for the space of five ronths and four days..." for shirking his duty, then Jater was found to be innocent of the charge. 17 Beaver complained that the Islanders had received no religious instruction even though some of them had been with the Company for several years. Even recent arrivals from the Islands, where they had been taught by missionaries since 1820, guicily forgot their Christianity. The women who accompanied the Kanakas were "...more than commonly depraved."

This last criticism Beaver aimed at all the Company employees including Mcloughin, but he feit the solution as applied to the Islanders was careful screening by an HBC agent in the Islanas before Kanatas were allowed to enroll with the Compary. He also wanted to establish a requirement that the rew Kanaka employees have a certificate of baptist and a marriage license. 19 Beaver's report also stated that the small advance the Kanakas received before leaving the islancis had to be given to their chiefs, clothing for the colcer climate might cost an entire year's wages, and a $100 \%$ mark-up was charged by the Company for necessities.

14

Beaver Letters, p. xxi.

15 mo the Aborigines' committee of the meeting for sufferines... Oregon Histurical Society, Beaver MS. 372. Hereafter cited as MS. 372.

16 Eeaver Letters, 0.86 .

17 MS. 372 .

18 Eeaver Ietters, p. 131 . 
Beaver's report created a furor, not only at Jancouver but also in London. James Douglas wrote in reply to Beaver's accusations that the clergyman was not interested in ministering to anyone, and certainly was not a champion for the better treatment of the Kanakas. He had refused to accept a marrieo Islander and his wife for house servants because he did not want to go to the trouble of teaching them. 21 Beaver also had refused to bury a Kanaka because he had not been baptised and when Mcloughl in read the services hinself, the chaplain loudly condemned such a "...profanation of the ser22 vice..." Beaver's incongruous behavior finally resulted in his dismissal by Douglas. He returned to England in Novenber, 1838, three years before his appointment expired, and died in South Africa on May $31,1858$.

The HBC's first experience with Christian ministers at Vancouver hâa been a most unhappy one. It was not surprising that McLoughlin and the London ccmmittee viswed with alarm the first American missionaries who appeared from east of the Mississippi River. What was surprising, however, was McLoughlin's decision to offer reasonable assistance to the

${ }^{19}$ Ibid.

20 Ms. 372 .

21 Beaver Ietters, pp. 131-3.

22 Ibid. The Kanaks that Mcloughlin buried in the fort cemetery was not, however, John Coxe, as clained by Kittelson for Coxe was still alive ten years later.

23 Beaver Letters, pp. xiit-xv. 
Americans rather than strictly enforce the Conpany directive to discourage in every way possible the likelihood that the missionaries would establish themselves permanently in the Northwest.

Jason Lee and his nephew, Daniel Lee, were the first to arrive in the oregon country. They were received hospitably at Fort Vancouver September 16, 1834, and McIoughlin offered helpful suggestions on where to locate their mission. In 1836 the Lees began builoing in the Nillamette Valley and soon were reinforced by another party sent out by their Methodict Mission Board.

Samuel Parker was the first representative of the American Board of Commissioners for Foreign Missions to arrive on the Pacific coast. He reached the Oregon country in 1837, visited the Methodist mission at Willamette Fills, and then returned Erst to urge the immediate organization of a mission to Christianize the Nez Perce and Flathead tribes located in the vicinity of Fort Walla Walla. Marcus Whitman, who had accompanied Parker on part of his journey in 1835, readed the first A.B.C.F.M. mission that arrived at Vancouver september $12,1836 .^{27}$ His party consisted of his

${ }^{24}$ Diary, Jason Lee, April 20, 1834-July 17, 1838. Oregen Historical Society MS. 1212 .

25 ibid.

26 parker to David Greene, Sec. A.B.C.F.M., June 27, 3837. Orezon Historical. Scciety MS. 1206.

27 David Greane to Lewis Cass, Sea. of War, Bobruary 25,1836 . Cregon Historical society MS. 1203. 
wffe, Narcissa, Mr. and Mrs. Henry H. Spalding, and William H. Gray. Whitman began to build at Wailatpu among the Cayuse, and Spalding located at Lapwai with the Nez Perce. 29

It was in 1838 that Mcloughlin applied to the Catholic Bishop of Quebec to send priests to the Northwest. 30 These Catholic priests, however, approached this new mission field with an entirely different concept than that of their Protestant counterparts and did not place the greatest emphasis upon acquition of wealth, permanent missions, land, or permanently located Indians. Neither did they, for some reason, attempt to convert the Kanakas, so far as avajiable records indicate. 31

Both missionary groups had arrived in Oregon territory with only the absolute essentials of quipment and food. The rest of their goods had to be shipped via the Jong passage around the tip of South America. They needed to builc shelters and plant crops as soon as they arrived in order to survive during the first winter, but they had brought no labor force with them, as they considered their primary duty was to the spiritual conversion of the Irdians rather than to raterial matters. But neither their faith nor the "savages" they had come to save could keep them from 2.8 Warcissa Whitman to Mrs. Serusha Parkor, October 3, 1838, MS. 1203.

29 Genry Spalding to Mr, and Mrs. Bridges, May 5, 1840. Oregon Historical Society MS. 1201 .

30 Beaver Letters, p. xix. 
starving during the first winter and so their welfare fell largely upon the shoulders of McLoughin and the services of the HBC. It was McLoughlin who supplied them with farm and building tools, and it was through him that the missionaries acquired a labor force of Kanakas, when the Rev. Hiram Bingham in the Islands was unable to fill their recuests. The missionaries had only just begun their new tasks when they discovered that the Indians were unreliable as a labor force because they were neither sedentary nor willing to accept unauestioningly the white man's concept of civilization. The Indians craved the power the strangers exhibited but not the drudgery or inferior status the missionaries insisted they accept. Kanakas, however, were highly recommended by the $\mathrm{HSC}$ and immediately pleasing to the missionaries for they were not "native savages" who needed to be taught the ways of civilization.. They would be willing to become farmers instead of hunters and would agree to live on a small plot of land so the remainder could be taken by superiors. The Kanakas then represented a viable labor force that, for the moment at least, posed no threat to inissionary dreams of spiritual conquest or to the growing preoccipation of the clergy with material wealth.

Kanakes were employed by both the Methodist and A.B. C.F.M. miscions. Jason lee reportea to his mission board

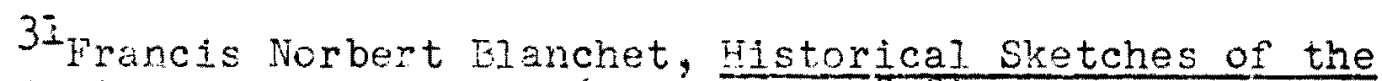
Catholis Church in Oregon... (Portiand, I878).

32 Alexarder Simpson to McLoughlin, Oetober $1,1840$. HURS Vol. VI, p. 239. 
that the Kanakas were used in groups of five or six for building purposes, and that farmers usually had three except during harvest perioas then more were hired. 33 Their wages were $\$ 10$ a month, the salary paid by the HBC, although the Islanders preferred "...\$74 a year, Beaver prices." 34

In March, 1843, Gustavus Hines, another of the Methodist group had written the boara complaining about the treatment of the Islanders and accused Jason Lee of mismanagement of the Methodist missions including the mission farmers who were allowed "...a numerous gang of 'Tanakas" whose labour does not pay their board, but who are paid ten dollars per month whether sick or well,..." ${ }^{35}$ Before his death, however, Hines reversed his position and contradicted the contents of this letter. 36

Alvan Waller was another Methodist who deplored the treatment given the Kanakas and wished to do something to 37 improve their situation. Their dependability and loyalty made them less heathen in the eyes of the missionaries and plans were made to acquire a number of them to come to Oregon to act as instructors for fellow Kanakas and to hold services for them each Sabbath. 38 The plan did not materialize through the missioraries, but it was less than a

33 Statement before Missicnary Board of the Methodist Church, July I, 184\%, Jason Lee MS. 1212.

$3^{1+}+$ bid.

35 Ibja.

36 Methodist Missions MS. 3224. 
year later that McLoughlin sent to the Isiands for a Kanaka minister. 39

Both Methodists and A.B.C.F.M. pensonnel came to rely more and more on their Kanaka laborers. They worked on the farm, in the kitchens, and learned blacksmithing sliils. If they left to return to Hawaii, or to find other employment, their former employers expressed great distress. In 1843 , J. H. Jucison wrote to Amos $\mathrm{S}$. Cooke in Honolulu requesting a married Hawaiian with his wife. He admitted trat plenty of Indians were available "...but they are not such help as we need, especially if our families are sick Indian girls we cannot get unless we taine them at an age so young they afford us no help and even when they grow up they very frequently run away." Judson further claimed to have made arrangements for the four to five Kanakas employed by him at Mission Mills to have Sunday meeting facilities. Such improved conditions should be considered, Judson wrote, before rejecting his requests for additional Kanaka help, but in any case Judson promised to "...trust the future in the

37 A. F. Jaljer to Amos Cooke, Argust 25, 1842. Cregon Historical Society MS. 1210.

38 I. H. Judson to Amos Cooke, August 6, 1843. Oregon Historical Socjety MS. 1223.

39 Hussey, Fort Vancouver, introduction.

40Ms. 1212, ibid. Tenry Perkins to Daniel Lee, January 4, 1839. Oregon Historical Society MS. 1211.

4iason to Cooke, August 6,1843 , 1 bid. 
hands of God believing tliat whatever privations I am celled to endire after maling all dne efforts to present them shall be over-ruled to our good." 42

A. B. Smith, of the A.B.C.F.M. mission at Kamiah, al so wrote his superiors lamenting the lack of reliable Indian labor and wondering how he would manage withont the Haweitian who had left him recently "...principally on account of his being alone, having none of his countrymen with him to converse with."

Both Whitman and Spalaing employed Kanakas at their stations. Narcissa Whitman was particularly impresseci with her Islanders not uniy because they were such good laborers but also because of their kind feelings and strong loyalties. In one of her many lettens to her mother she asked that her mother renember the Kanalsas in her prayers, a sentiment she did not express at any time tcward the Incians at failiatpu. When one of her Kanalras, Joseph, became ill and died, Narcissa geain wrote to her zother lamenting, the death. "Our loss is very great $[\cdot]$ te was so faithful anc kind alwaycs ready and anxious to relieve us of every care..." 46 " Narcissa was certain his soul had been savea.

42 Ibid.

$43_{\text {A. }}$. B. Smith to Rev, David Greene, August $31,1840$. Oregor Historical Society, MS, 1200. M. .203.

14 wercissa whjtman to kns. Prentiss, December 5, 1836.

45 Ibia., october $9,1840$.
46 Ibid. 
When one of the Hawaijans at the Methodist mission died, a similar expression was witten in the journal of one of the mission teachers. "Rora, the Hawaiian, a falthful servant of the mission died in full assurance of a. home in heaven... c It is aj Pleasing reflection that Rora... is now praising God in heaven with as favorable acceptance as the delicate European." 47

In one instance one of Spalding's Kanakas stepped in to protect his life curing a bitter argument between Epalding and an Indian. Accoraing to an apocryphal acoount related by Cushing Eells, a Kanaka also was jinvolved in events following the Whitman Massacre. One of the Islancers at Fort Wallá Nalla was sent to Fort Vancouver to inform VicLoughlin of the massacre. On his return trip he was intercepted by Indians near The Dalles, tied up and threatened with death unless he cooperated by detailing the action planned against the Cayuse. The Kanaka refused to speak so his brains were beaten out on a stone and his body thrown 49 into the river. There is no official record of such a messenger being sent but such an oversight could be explained by the excitement of the moment. The animosity between Indians and rawailans has been mentioned previously

47 unnal entry liovember 21,1839 , whe Grains... oregon Uistorical Society, Eelunap Ma. 91 ond 92, p. 118. 48 A. B. Smath to David Greene, october 21, 1840. Cushing Eeliz to Greene, December 10, 1847. MS. 1200. 49 Eeris to Greene, ibid. 
In the use of the Kanakas as punitive forces against various tribes by both the North West and Hudson's Bay Companjes. It is therefore quite plausible that such revenge was perpetrated on an indivioual Islander.

Kanakas also were more easily accepted into the church than were the Indians. In 1839, Henry Eerins described a religious revival helc at Mission House in which a Kenaka and Hiliam A. Slacum were converted at the same time. The Hawaizan, Charles Cahanaiah, was learning the blacksmithing trace at the mission. He attended the revival meetings and during one of them rearested to be admitted into the lieth50

odist Church. The missionaries did not doubt the Karaka's sincerity as they frequently did in the case of the few Indians who recuested acceptance.

In Tune, 1848, Rev. George Yenry Atrinson arrivad at Fort Vancouver aboard the Cowlitz. He wonld ultimately labor in oregon country for forty years on behalf of the Indians, Chinese and Aläskan natives, anỏ serve as education advisor to Governor Joseph Lane. He visited Fort Vancover after first arriving on the coast and aescribed

50 Eenry Perkins to Daniel Lee, January 4, 1839. MS. 1211. Wiliam Slacum was sent to report on the oregon Territory in December, 1836, by President Jackson.

${ }^{5}$ A. B. Smith to Greene, September 3, 1840, MS. 1205. 52 wiory of Rev. George Henry ktkinson,D.D., 18471858," ed by Ruth E. Rockwood. Oreson Historicai Quarterly XXY (Waroh, June, Soptember, December, I959), 57-60. Tereaiter atert as "Atkinson Diany." 
the fort as a parallelogram with inclosed houses for offices and clerks, a fur store, trading shop, bakery, meat shop, and offices. Peter Skene Ogder had a Catholic priest living with him but Kanaka Nilliam had his own house in the 54

rear of the fort area. Later simpson replaced McIoughlin with James Douglas who moved both Catholic clergy and Kanaka William outside the fort area to increase storage facilities within the enclosure. 55

Atkinson äescribed Kanaka Villiam as a Christian missionary to his people with twenty to forty members in his church. He was not ordained but enjoyed an excelient reputation. He reported weekly to Cgaen on the number of his countryuen who had been drinling during the previous week -- the most serious problem among the Kanakas as weil. as the other HBC enployees. "They drink without mercy, bay it on Saturday and have sabbrth to get sober in so as to work on Monday." 57 Durirg Atkinson's visit at the fort he also watched Indians, Kanakas, and Scots shearing 15 to 20,000 heac of sheep. On June. 20 he called "...to see the Hawaijan Cox, who saw Captain Cook mirdered. He [was] about 82 yeare of age. He [had] travelea scme, to Eng[land, Amcericas etc. [Ccxez Joes not wish to go to the Is] andis, does rot care to attena meeting."

$$
53 \text { Ibid. } 181 .
$$

55 Threas ancierson, "The Varcouver Reservation Case. A Legal Romance," Oreson Historical Quarterly, VIII (Septenber, I907), 223 . 
Rev. Jamon also visited Vancouver and John Coxe during his journey along the Borthwest coast. Fe conversed with other Kanakas at the fort, although by 1849 many of them had left for the California gold fielos. Lamon was impressed by the fact that the HBC had hired Kanaka Nilliam as a preacher and school teacher although "...he was laboring under serious hindrances, in consequence of so many... becoming (Dalaira) indifferent to religion."

A] though the Kanskas apparently had no contact with Catholics in the Northrest, and had expelled them from the 61 Islands, they were exposed to the new vormon reliaion in 1844 and quiclily acopted its teaching. In 1846 sam Branon and his Mormon party touched at the $2 s]$ snds on their way to California and on lecember 12, 1850, penry Bigler and nine uther Yormons arrived to berin the first Vorma mission 63

in Newail. One of this group, George Q. Cannon, trans ated the Book of Mormon into Hawaiian between 1852 and 1854 .

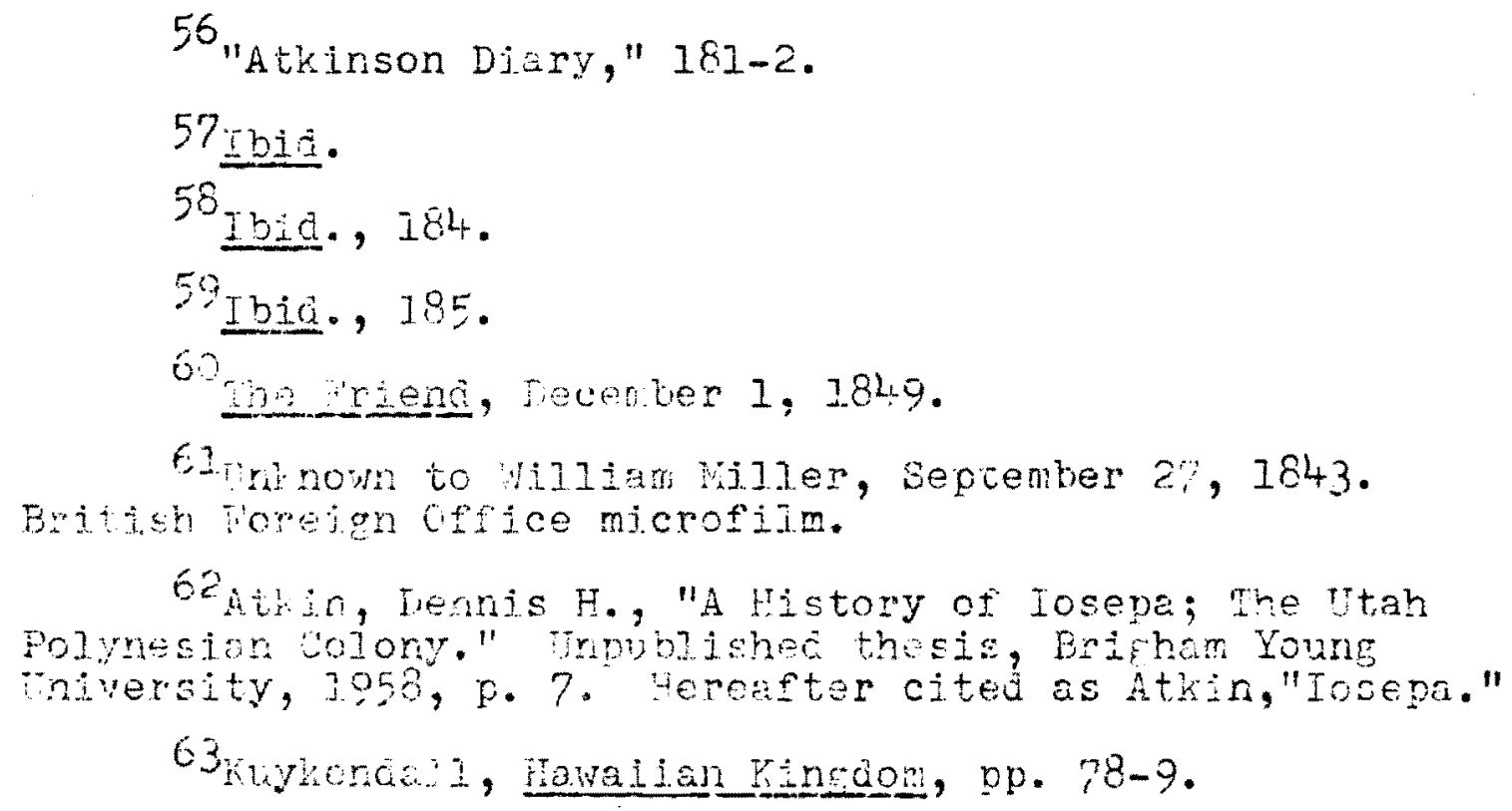
Brittsh lorejgn lefice microfim.

62 Atrin, Denis H., "A History of Iosepa; The Utah Polynesian Colony." Wrpublichec thess, Brigham Young niversity, 3958, p. 7. Gereafter cited as Atwin,"Iosepa."

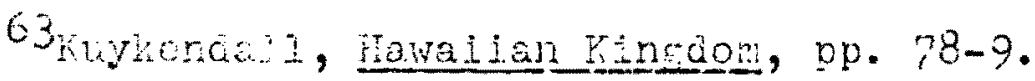


In 1854 a Cjty of Joseph was established on Lanai Is]and to serve as a temporary gathering place until all the Hawaiian Mormons cculd travel to ttah.

Bigler soon left the Islancis to return to Utah but in 1857 Brigham Young asked him to prepare another mission to Hawail. This he did, followed three years later by walter Murray Gibson who had received permission from Young to start another Mormon mission.

This sustained Vormon activity was little appreciated by the protestant groups who had until this time enjcyed a monopoly of missionary enterprises in the Islanos. Fven the British Consul, 洼liam Miller, became concerned and wrote to Londion for instructions. He received instructions to advise the dawailan government to object to the immigration of the Mormons and to forbid their landing by passing temporcry legislation. Miller also was advised that the British admiral in the area had been directed to give assistance, if the Hawailar government recuested it, in keeping the romons from attempting to land by force.

64 "Extracts from the Journal of Henry W. Bigier," Utah Historical uarter?y, 5 (April-october, 1932), 138 . Ferenter cited as "Bigler Journal." Kuykendall, ibid.

65 Kuyendail, ibid.

66"rigler journal," 141 .

67 The Frieno, october $1,1864$.

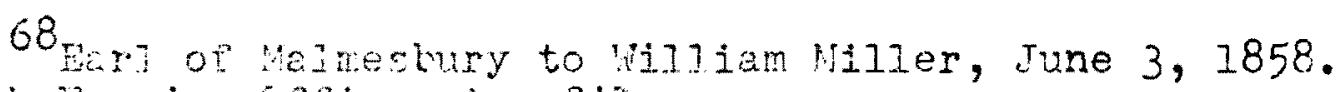
British Toreign cffice microfilm.

59 Ibia. 
Gibson, however, defeated much of the Mormon attraction on the Islands by his peculiar actions at Lanai where he gave himself the title of Chief Presicient of the Island of the Sea, sola church offices, and claimed great progress with Hawailan children unti]. their parents interfered. Organization, he said, was his aim, not preaching, since the Is]anders already had recejved too inuch of that. A delegation arrived from Utah in 1864 anc accused Gibson of acouiring lends under the guise of head of the Mormon church. They also condemned Gibson for taking money from deiuded natives, who "...have invested their morey in the Mormon church, anc they would be very glad to get it bacl." Gibson denied taking such money or investing in lanc at Ianai stating that "There [ weres no such lands in this kingdom, ... Certain natives constituting a Normon Society, dio design to purchase land on this island,..." but they had facied. Brigham Young was not convinced of Gibson's good intentions ho'vever, and he later left the Islanas.

Gibson's self-emulation may have quieted the fears of the Protestant leaders and British representatives on the Islans, but it did not seriously effect the determination of those ranakas converted to the Mormon faith to join the gathering in utah. Unfortunately, st was also at this

\footnotetext{
$70_{\text {The Friend, October I, } 1864 .}$

7]Ibid.

72 Novenber 4,2864 , ibid.

730 ctober 1, 1864, ibid.
} 
period that the Island government was making its strongest efiorts to keep all Hawaiians at home anci it was not until 1867 that one Kanaka, Napela, was allowed to visit the Mormon territory. His praise of Jtah and the church's progress there increased the pressure on the Hawaiian government to release Kanaka Normons until finally, in 1883 , several were given permission to imigrate.

These first islanders in Utak settled in salt lake City and by 1889 approxinately : eventy-five were living in the city. They encourtered problems, however, in being assigned to the most difficult and least cepencicle type of work. 77 This indication of non-assimilation prompted the first presidency of the church to appoint the trawaian Colonization Committee in 1889 to select a permanent and more 78 agresable jocation for the Kanakas. All of the comittee members hac been missionaries to the Islanis, and tie raneke commuity at Salt Lale City were asked for their opinions and 79 recommerdations. By rune of the same year it was decicied

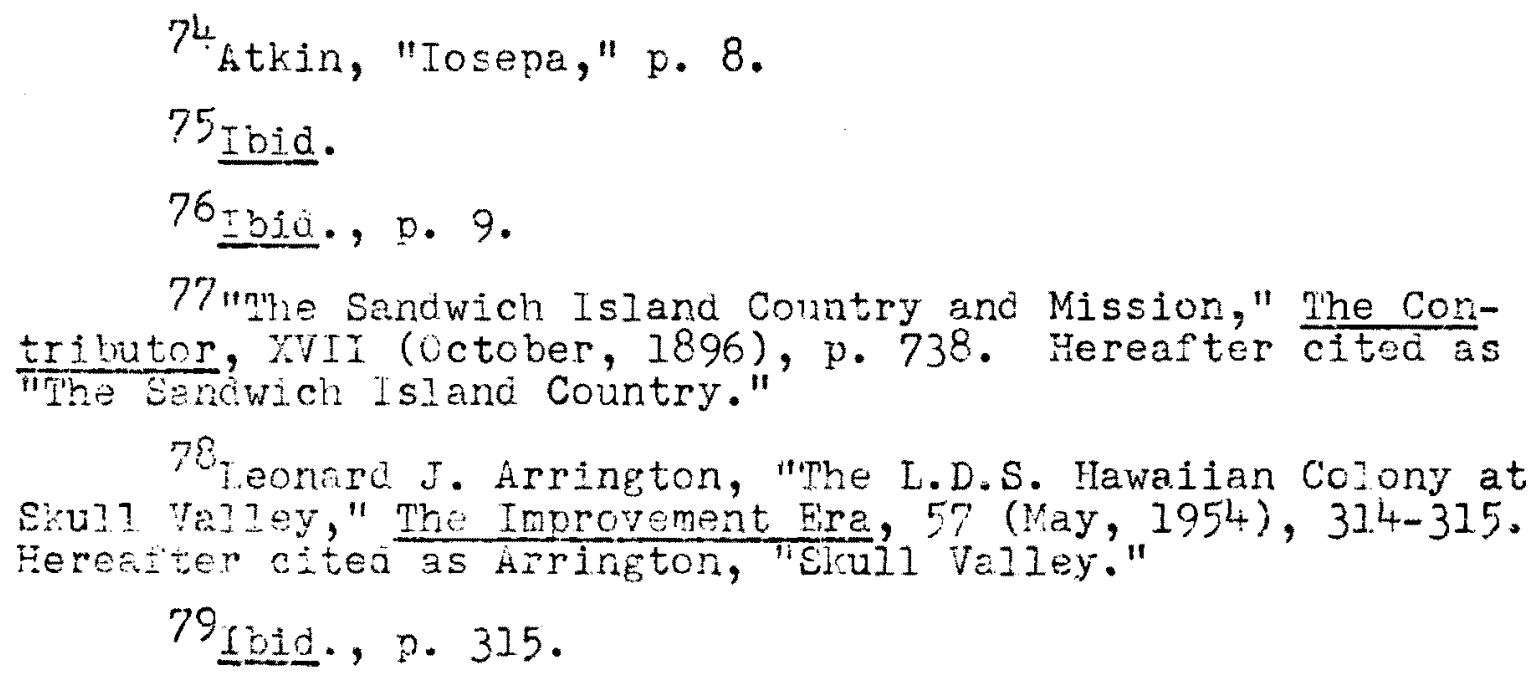
tributor, XVII (october, 1896), p. 738. Hereafter citedas "The Senciwich I sland Country."

7 Seonard I. Arrington, "The L.D.S. Hawaiian Cojony at Skul1 Val 1ey," The Improvement Era, 57 (May, 1954), $314-315$. Hereater cited as Arrington, "Elkuil Valley."

79 loid., p. 315 . 
to purchase a Skull Valley ranch owned by John T. Rich, located seventy-five miles southwest of the city. The property consisted of I,920 acres with good water, a supply of timber in the nearby mountains, and a saw mill already in operation five miles to the east. Rich also was willing to seli his livestock consisting of 129 horses and 335 head of cattle. No Indian threat had to be considered since most of them had already been relocated on reservations in Juab and Jintah counties.

The new Kanala home was named Iosepa in honor of Joseph F. Smith and the Iosepa Agriculture and itock Company was forred to administer operations. There were seven stockholders, one of whom was I. W. Kauleinamoku who wculd become the leader. of the Kanaka colonists. The other acministrators selecteo were Americans. In this respect Iosepa was unicue among the Mormon colonies for it was not ruled by its settlers. Each of the stoclholders was entitied to a city lot at Iosepa, the company was to acquire

${ }^{80}$ Atkin, "Iosepa", p. 10; "The Sandwich Island Country" $738-39$.

81 Arrington, "skull valley," 315.

82 stkin, "Iosepa," pp. 2, 10-11; Arrington, "Skull Valley," 3It.

83 Arrington, "Skul] Talley," 315; "The Sandwich Island Country," 739. Iosopa is the Hawaizan word for Joseph.

G4arington, "Skull valley," 1bid.

85 Atkin, "Iosepa," p. I. 
all lots fronting on the town square, and lands adjoining the townsite were to be homesteaded under the Desert Land or 86

Tree Culture Acts. The company seal was a rising sun with a motto in Hawaiian.

The first Hawailans arrived at their new home on August 28, 1889. On this Hawaiian Pioneer Day forty-six Kanakas drew lots to determine their land portion, and began the tasks of building houses, a schoolhouse and store, laying out streets, and constructing an irrigation system. A death in September made it necessary to select a location for a cemetery. 90 The ecciesiastic organization at Iosepa, in contrast to that of its administration, included several Kanakas as president of the Teachers Quorum, counselors, and suncay school superintendents.

Iosepa harvested good crops the first year and additional income was obtained by either selling feed to other ranchers in the area or contracting to care for the livestock of neighbors through the winter. Gradually, the Kanakas purchased their own animals including cattle, sheep 92

and hogs. By 1892 the colony was reported to be

86 Atkin, "Josepa," p. I; Arririgton, "Skull Valley,"365. 87 Arrington, "Skull Valley," ibj.d. 88 Ibid.

89Arrington, "Skull Talley," ibid; J. Cecil Alter, "latter Day Colonizing by Latter-Day Saints," The Deseret News, Decencer $16,1911$.

$$
90 \text { itrin, "Iosepe," p. } 17 .
$$


prosperous with "... four hundred acres under cultivation in hay and grain...over three hundred toris cof lucern $n_{3} .$. wheat, oats, and barley...about six thousand bushels...candz enclosed with cedar posts and wire fencing...,1600 acres..." 93 Workers received either a daily or monthly wage according to their work and then charged their purchases through the company directly against this wage. No money was paid or spent until after the beginning of the twentieth century. Infortunately, Utah and all of the United States suffered through a severe depression in the 1890's which forced down farm prices and threatened many businesses with bankruptcy. This situation affected Iosepa to the extent that, by 1897, the First Presidency seriously considered renting out the site to a private rancher to operate. 95 This drastic step was not taken, however, and by the early 1900 's Iosepa was consiciered "...the most successful individual colonization proposition thet has been attemptec by the 'Miprmon' people in the United States..." 96

It was to the credit of these yawaiian yormons that tre above statement should be airected since there were only six Americans who lived at Iosepa. What was accomplisher there in the twenty-eight years of its existence

$$
92 \text { Ibid. }
$$

93arzirgton, "Skull Valley," 366; Deseret Evening News, December 22, 1894 .

gitrtinin, "Iosepa," p. 23. 
was through the hard work, perserverance, and courage of 97

its Kenaka residents. These Islanders created a community in the desert with wide streets, neat houses, lawns, and flower gardens. 98 Iosepa's cleanliness was well known; its citizens formed musical groups and participated in various athletic activities and supported the Mormon Church both by example and monetary contributions. Education also was taken seriously and a school was operating in 1889, while in other respects the Hawailans exhibited an amalgamation of Island customs with those of their Vtah neighbors. They remained fond of poi and seafood, substituting wheat fjour for taro and carp for the abundant fish life of the Islands. But they also accepted American cesserts, clothing, and the music of the area. Iosepa's citizens enjoyed the privilege of voting and took this duty seriously al though they never became active politically.

Although the colony had financial difficulties, work was always guaranteed throughout the year. There was some agitation for higher wages in 1894 but prompt action by the board of drectors eliminated further problems. At

$$
\begin{aligned}
& 95 \text { Arrington, "Skull Valjey," } 366 . \\
& \text { S5 rhe Deseret News, December 16, } 1911 . \\
& 97 \text { Deseret Evening News, December 19, } 1903 . \\
& 98 \text { I bid. }
\end{aligned}
$$

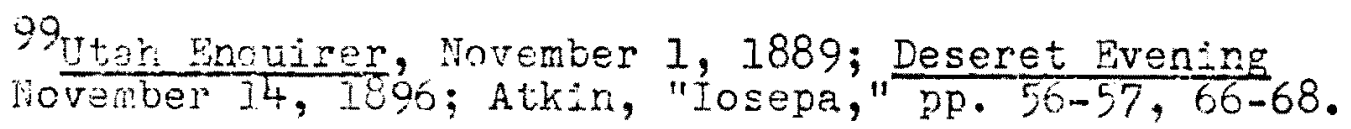

$$
\begin{aligned}
& 100 \text { htkin, "Losepe," p. } 29 .
\end{aligned}
$$


this time men received from $\$ 1$ to $\$ 1.50$ per a 10 -hour day, women .50 to .75 , and boys .25 to .75 per day. 101

The many hardships and adjustments that faced the Kanakas did not result in any rovement to return to their Islands. In fact, it was the Hawalian government that made repeated efforts to entice the Iosepa citizens back to Hawaii. In 18,4 they were offered free passage to return, and the Church presidency announced they were free to do as they pleased. Although there were a few who accepted this offer, they were at the Islands only a short time before they 102 began to seek ways to return to ttah. After Hawaii became a United States territory in 1898 a few Iosepans returned to the lslands, but no further efforts were made to entice them away from Utah untiI 1917.

It was in this year that the Church sold Iosepa to the Deseret Iivestock Company anc the Kanakas returned to 104

their homeland. There were several reasons for the closing of losepa: (1) the frequent outbreaks of illness among the Kanakas, incliding leprosy; (2) the financial problems of the Mormon Church which made it difficult to continue support of Iosepa even after it began to prosper; (3) the

${ }_{101}$ Ibid., p. $4 \%$

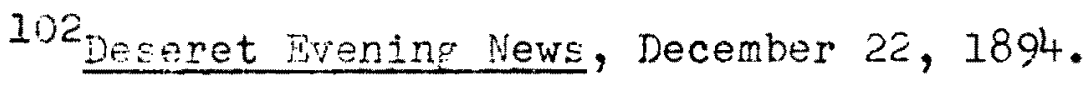
103 yid.

Iol Heraid Republican, November 1, 1917; Deseret evenise Neve, woverber 1, 1917.. 
building of a Mormon temple at Laie, Oahu. The location of a gathering place on the Islands left littie reason for the Hawailans to remain in Utah, but there were still many who did not wish to leave. The Church agreed to assist financially, however, and after one large group left those remaining behind realized that Iosepa could not be continued. Today Iosepa is dead. Most of the houses were torn down and the streets and cemetery overgrown with weeds. But the Kanakas who built Iosepa proved themselves capable of enterprise, self-government, and perserverance in the face of great cods. As they had exhibited great loyeity and ability to the fur companies and missionaries of the pacific Northwest, so they remained loyal to their chosen faith even though it had meant isolation and illness in the vtah desert.

105 Atkin, "losepa," pp. 78-81; Salt Lake Herald, June 20, 1896. 


\section{CHAPTER IV}

NEW SEILIS AND NEN ADJGMTIRES

The Kanakas had proven themselves valuable laborers for the fur trade companies, for the American missionaries, and for themselves. They had expanded their skills to incluee those of bcatmen, loggers, blacksmiths, farmers, and bujlders. Now as the oregon country ard California began to attract many now settlers from the United States, the Kanakas discovered that these abilities created new demands for their labor.

When Edward Vischer traveled to Californis in 1842 to establish himself as a merchant, he arrived abocird the schooner California. According to Vischer, all of the crew of his vessel with the exception of the captain, mate, cook, anc steward were Kanakas. "These Kanalkas," he wrote, "have become almost indispensable for the ships along the cosst of California." They were superior in handing boats and performed most of the less technical tasks. Many of the captains who were unfamiliar with the pacific shore believed they owed their lives and the safety of their ships to the

"Ecivard Vischer's First Visjt to Celifornia," tr. and ed. by Ervin Gustan Gudde. Californie Historicas esciety Quarter1y, 19 (Ceptember, 1940), 193.

$$
2+\mathrm{eia}
$$


Kanakas. Vischer also remarked on the conauct of these Islanders as being praiseworthy, modest, sensitive, and willing to share. The log of the Emily Bourne which touched at Hawaii in 1832 also contained a comment upon the excellent ability of the Kanakas in handling boats.

In 1843, James Douglas arrived in the Northwest to survey an area for a new HBC fort at Victoria on Vancouver Islanc. The construction of the fort began June 4, 1843, and after its completion roads were built in the area. These roads were constructed by using boulciers as a foundation and then placing six-inch planks side by side for a walkway. "All the heavy labour was done by Indians and Kanklas...the latter being expert axemen."

By 1846 the population of Oregon country was estimated at 9009 , not incluaing the Indians. There were also about thirty Negroes "...and about double that number of Kanahas or Saniwich islanders! These last "act ed $_{j}$ as cooks and house servants to those who [could] afford to employ them." It was also during 1846 that Captain John Paty became naval suprrisor for the Hawaiian king and the king's representative on the American Pacific Coast. During Paty's

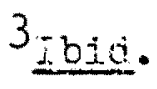

"Heward doesting anc D.E. Livingston-Little, "A Scotsman viewe Hawaii..." Journal of the West, II (Apri1, 1970), 196.

5 Farry Gegson, A History of Victoria $1842-1970$ (Victowa. B.C.: Yictoria Publishins Co., Lta.,1970), p. 6. Horostor citor as Gregson, lictoria. 
American journeys he found fifteen Kanakas at Acapulco, Mexico, scme of whom had served in the Mexican naval service. He also noted many of the Islanders in California. The Northwest settlers were just beginning to realize the wealth represented by the thic' forests that covered their mountains, and lumber mills were among the earliest private businesses. In 1843 such a mill was built thirty miles east of Astoria by Henry H. Hunt and B. T. Wood. ${ }^{9}$ In 1846 , A. E. Wilson bought out Wood's interest and introauced the first Kanakas as laborers there. Wilson contracted for the Islanders at five collars per month with board included (salmon and potatces), aid each Kanaka received twenty-one dollars in advance before leaving the Islands. 10 At first there were Iive Islanders including George Washington, but 11 in 1847 a sixth Islander was hired. Anson Sterling Cone and Clement Adams Bradbury, both from the eastern United States, also were employed at the mill and learned to respect 12 the abilities of the Kanakas. According to Bradbury,

6 Report of It. Neil M. Howison, U. S. Congress, House, zoth Cong., lst sess., H. Doc. 29, February 29, 1848.

'Greer, "wandering Kamaainas," 223.

Ibid.

9 John Minto, "Trom Youth to Age as an American," Oregon Fistorical ruarterly, IX (June, 1908), 128.

10, Astoria Mills, Columbia River, ledger, Sept. 1, 1845Anril 30, 1847 . Orequn Fistorical Scciety MS. 979B. Hereafter cited as Astonia Mils ledger. Minto, "From Youth to 4ge," inde. Il Astoria Mills ledger. 
however, the wages for white lumbermill workers were twenty dollars a month, paid in script and grindstones. 13

During this same period twenty-five to thirty Islanders were worling at the HBC mill near oregon City in positions from hewers, fodciers, and rafters, to sawyers. 14 The Cregen Milling Company also employed Kanakas and in 1846 the Spectator reported an accicent there in which "...a Sandwich Islander, came very near having his leg amputated by.... a saw." 15

Labor costs were high and continued to rise through the $1850^{\prime} \mathrm{s}$, which benefited the growing number of Kanaka laborers. There were several reasons for these high labor costs: the initial expense of reaching the Pacific ccast for American laborers, the lack of training in mechanic's skills for young Americans growing up in the area, and business speculation coupled with high interest rates. The Kanakas, however, were brought to the coast at someone else's expense and vere not averse to manual labor. They were thus in constant cemand, a need that obviated any prejucice at least for the moment. Wages were paic to Islanders in San Francisco by the town council without deliberation and with

$32_{\text {H. }}$. S. Lyman, "Reminiscences," Oreron Historical Quarterly. II, IV (September, 1901 and 1903), 315; 251.

13 Ibia., II, 315.

24 Hussey, Fort Vancouver, p. 200.

15 Oregon Spectetor, February 5, 1846. 
no demand for a union card. As common laborers work was always available at $\$ 3.50$ to $\$ 5$ per day, while on the East 78

Coast such labor paid only $\$ 2.50$ per day.

Ship's carpenters brought $\$ 10$ per day, biacksmiths $\$ 8$, Iongshoremen $\$ 6$, and farm hands $\$ 50$ per month. 19.11 of these wages were at least double those paid in the Past whe bricklayers were paid only $\$ 13.50$ a week and farm workers only $\$ 22$. Il a month. Kanaka longshoremen in San Francisco earned the per day or approximately $\$ 156$ per month. As common laborers in California, they received $\$ 78$ while those Islanders still employed by the Oregon missionaries as farm hands or by the HEC were receiving cnly 10 per month. Given this wage differential, it is no wonder that many Ranakas traveled to California even before the gold rush had begun. According to the 1850 census, Califocnia had 319 Islanders while the number in Oregon had dwind 130 to 50. A great number, however, were along the eastern coast. Massachusetts c]aimed 89, Connecticut 45, Hew York 40, and Rhode Island $8 .^{22}$ Kanakas also were living in some of

16 John Hittell, The Conmerce \& Industries of the pacieic.... (San Fruncisco: A.I. Bencroft \& Cc., 1882), p. 90. Horeatter cited as IIttell, Commerce.

17 Revisw by Robert Ernest Cowan of San Frencisco Tuwn Tournol. 1847-1848. Cyliformia Historical Society GurterIy, $\because$ (jecember, 1926$), 407$.

18:itte11, Conmerce, p. 99.

i9soulé, Annars of San Trancisco, pp. 459-60. 20 aittel], ibid. 
the southern states such as Alabama, Virginia, Louislana, and Texas; and in the widwestern areas of Chio, Michigan, Illinois, Missouri, anä Wisconsin. 23 Kanakas never formed a majority of the working force in any area after 1845 , but their influence was felt throughout the Inited states especially in the area west of the Rccky Mountains.

Kanaka impact was greatest as seawen; indeed, their abiltities in this respect had been recognized as early as 24

1811. Walers and merchant ships sailing out of eastern ports customarily stcpoed at the Islands to obtain Kanaka reinforcements. The cantain of the brig Ann, of Sryunt and Sturgis Company, Boston, was only one who received orders to sail to Hawaii and "Take as many stout Islanders as yill increase your crew to 21 or $22 \ldots$ and when you return from the cosst [Pacific Northwest] discharge and pay them of in such articles of trade as you have left..." ${ }^{26}$ Most American ships not only stopped at the Islands enroute, but also returned to winter there. 27 It was an excellent situation 1853).

21 MS. 803. Seventh Census of . S.: 1850 (Washington, 22 Severth Census, ibid. ${ }^{23}$ Ibid.

24 . S. Congress, Touse, H. Doc. 29, ibid. 25 ibia. 26 kuykencal1, Hawalian Yingdom, p. 88. 2? HBES VOI. XXII, p. 615 . 
for both parties -- the Americans could acquire seamen of ability at Iow wages, and the Kanakas did not have to sign three-year contracts or winter in the cold climate of the Northwest.

As the number of American and foreign vessels stopping at the Islands increased so also did the number of Kanakas joining them as seamen. The tonnage of Amprican vessels employed in foreign trade jumped from 706,463 in 1815 to 877,031 in 1816 . By 1829 the value of the cargoes of those stopping at Havaii was estimated at $\$ 4,000,000$ and between $1824-44$, 52 war ships and 1712 whaleships, three-fourths of which were American, had entered Island ports. In 1823, 200 Kanakas had signed on whalers, in 1832 there were 400 , and in $1836,600$. . For the period $^{30}$ For January 7,1843 , to June, 1844, the following number of Kanakas had been recruited: for whalers, 114; California merchant vessels, 51; Columbia River trade, 50; French ship Lion, 12; vessels to Mazatlan, 10; to Valparaiso, 8; Russian vessels, 6 ; and vessels trading to China, 5 .

Aciventure was not the only reason that so many warnairas left their homes. The wages on the Islands were low J.h contrast to those paid aboara the foreign vessels. Finsirilled labor ashore averaged from $12 \frac{1}{2}$ to 50 cents per cay, \$2 to $\$ 6$ per month, while Kanaka seamen were paia $\$ 5$

20 Sististical Annels...of the Mnited states of America (Philadelpha: Thonde Lobson ic Son, 1818), p. 319. 29 Birinan, Residence of Twenty-one Years, p. 358. 
to \$12 per month on merchant vessels.

Aboerd whalers they were paid by 'lays', or shares, which varied from l20th to 250 th of the value of cargo taken. Most Kanakas as well as the majority of American and European seamen received 140 th to l50th shares.

\section{3}

The Islancers were eagerly sought by foreign coptains, all of whom held high respect for Kanakas under their employ. They were considered subordinate, docile, good natured, and trustwrthy. Their swiming abilities made them especlally useful for handing boats in rough surfs. Many Hawajian seamen never returned to the Islands, but those who did were "...readily distinguishabie amongst the pofulation, by their supericr cleanliness, dress and assimilation to foreigners in their manners and habits." 35

However, the ract that many Kanairas did not return home became a major concern of the Island government. The Hawaiian census in 1349 showed a continuing decrease in the native population and the "]arge number of Hawaiian youth who have jeft in whaieships and never returned" was

30 Greer, "Wanciering Ramainas," 222.

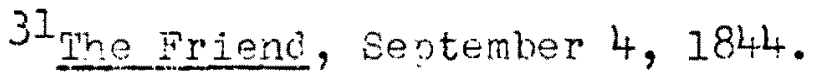

32 scrmitt, "population Cheracteristics," 358.

33 Ine Friend, ibia.

34 rbid.

35 Ibid. 
considered a major cause of this decline. 36 The numbers who left annually "was computed at 4000," many of whom left wives and families to fend for themselves.

Two measures were taken to meet this popilation decline crisis. First of all, after 184 ' native seamen could be hired only at the ports of Honoluln and Iaheina, and then only with the governor's consent. 38 away hanakas without such permission would be fined $\$ 400$. Those leaving, whether "...domicilea alien, naturalized foreigner or native," had to present a passport issued by the Hawaiian Minister of Foreign Relations. 39 Vessels discharging Kanfikas had to do so it the designated ports of ronolulu and Lahaina. These at tempts at control did not decrease the number of Kanakas leaving the Islanas but it did increase the funcs in the Hawaijan treasury since taxes were assessed against "Shipping Natives.". 41 In 1847 , the gross receipts from this tax, at Honoluliz only, were 876.25. In 1852 the amount received at Fonolulu was $\$ 950$, at Lahaina, 457.50 .

The second measure taken by the llawailan government was to assess a second tax against those Kanakas leaving

$$
\begin{aligned}
& 36 \text { mid. } \\
& 37 \text { Novenber 15, 1849, ibia. } \\
& 38 \text { september 15, 1852, ibid. } \\
& 39 \text { tebruary } 1,2847 \text {, ibid. } \\
& 4 \text { cris. } \\
& \text { irliebruary 1, } 1848 \text {, ibir. }
\end{aligned}
$$


families behinc to insure their proper support. 43 This measure was even more lucrative even though the amounts collectea were not supposed to be added to the Island treasury. Careful statistics were lept, however, and in 1852 the amount assessed at Honolulu totaled $\$ 1,003$, and Lahaina $\$ 708$. 44.

Kanakas also were serving aboard native vesceis that formed a growing fleet called the Yosouito Fleet. 45 aighteen Islancers were recruited for this fleet in $1843-44$. By 1872, twenty-six Hawailan vessels were manned by Kanakas and often the cantain was a native who had received his experience aboard foreign ships.

There was, of course, another reason why some Kanclas did not return to their homes. Al] seamen often met with tragedy and the Kanakas received their share. In a few cases they also became involved in mutiny or piracy, and frecuentiy they became ill and died at sea. John Colcord reported picking up three Kanakas at Norfolk Sound who had been left in California by their previous ship. They had

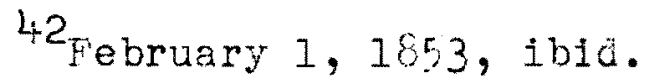

4 3 Simpson, Narrative, pp. 77-8; Greer, "Wardering Kamainas," 224.

$4)_{1}$ the Priend, ibid.

45 Juiy 1, 1845 , ibid.

46 Greer, "Wandering "Evalinas," 222.

47 The Priend, Ju2y 1, 1545 . 
then joined a second vessel which was attacked by pirates. The Islanders were the only ones left aboard so they steered north hoping to reach land. When they reached Norfolk Sound the Russians confiscated their ship but Colcord arrived soon after and returned them to the Islands. In 1834, the Chinchilla, captain [T.?] Meek, picked up two Kanakas stranded on Fannins's Islenc, and returned them to Hawaij. It was later discovered these Kanakas had been involved in the killine of their origjnal employer. Both were tried, found guilty, and executed.

shipwrecks were common and often fatal to crews. In November, 1842, the whaleship Holder Eorden, sailing out of Massachusette, was lost with a cargo valued at $\$ 65,000$. The crew which included five Kanakas, built a small boat from the wreclage and managed to return to Honolulu. When the whaler Baltic was wrecked of Kanchatka on June 16 , 1844, three Kanakas were among the crew that was lost. The Hawaiian schooner Paalua was lost in April, 1845, but her Hawailar crew nanaged to swim to land. 52 men the whaleship Iriton was attacked by natives off Sydenham's Is]and

48 Journel of John Nason Colcora. Oregon Yistorical Society NS. 234 .

${ }^{49}$ Tbja.

50 rhe Prienci, November 1, 1844 .

5ibia.

52 May 1,1845 and August 15, 1846, ibid. 
part of her crew was massacred. One Kanaka, however, risked his own life to protect that of his captain, Thomas spencer, and both eventually managed to reach safety.

Kanaka seamen who became ill aboard ship were an especial problem of foreign consuls along the Pacific Coast. Thomas 0 . Larkin, the American consul in California, attempted to care for sick seamen and operated a hospital in their behalf. In $184+1$ he accepted five Kanakas with smallpox from the vark Don Quixute. " Larkin, however, was not certain where his suthority ended and who he was authorized to accept. He wrote to William Hooper, Am rican Vice-consu] at Oahu, asking his acivice on accepting sick Kanakas from American ships. 55 Larkin felt that "From Mr. [Dariel] Webster's (former Secretary of state) opinjon that everyone under our flag is entitled to its protection..." that he must accept them. Larkin further iniormed Hooper that he looked "...tor many cases of Natives of your Islands being brought to this Consulate from American whale Ships. che had already] buried two Kanakas, and [was] attending to some others." 56 at the same time Larkin wrote John C. Calhoun, secretary of state, requesting his opinion on the matter.

53 september 1, October 1, 1848, ibid.

54 George P. Hammond, ed., The Laritin Popers... (9 vols.; Berkeley: University of Califcrnia Press, 1951) I, p. 96. Hereafter cited as Larkin Paners by volume.

$55 \mathrm{vol}$. II, p. $27^{i}$, ibid.

56 Ibid. 
Before he could receive a reply from either Hooper or Calhoun, Larkin accepted three Islanders from the brig Monmontri who were ill with scurvy. Captain H. B. Fedger certified that the Kanakas, "...John Pilikin, Harry Coffen and George Washington..." were releaced to be cared for at the Consul hospital. Pilikin and Coffen were later placed aboard the Don Gixote as foremast hands, but Washington reappeared in Oregon in 1846 as a lumber mijl hand.

In Noverber, 1844, another Kanaka named Peter Perry -was attacked by two California soldiers, severely cut with a razor, and robbed. 60 perry was employed as a house servant by Larkin, who immediately protested to Manuel Micheltorena, the Mexican governor of California. Larkin requested punishment of the attackers to the full extent of Mexican law as soon as possible. He also informed Micheltorena that one of the soldiers involved had made previous assailts. The punishment for at least one of the soldiers was only four months in irons and then transfer to San Blas.

Iarkin eventually received an answer to his question on acceoting Kanaka seamen although it came from the $T$. S. Ireasury Department, not Secretary Calnomn. Larkin had

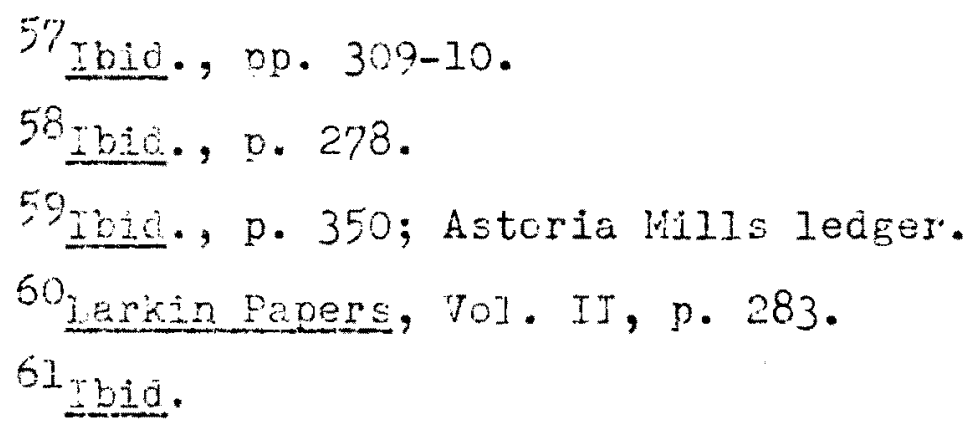


claimed an amount of $\$ 4$ for boarding the Isianders from the 62

Monmouth. On June 12, 1845, Stephen Pleasonton of the Ireasury Department wrote Larkin that "the Amount of Voucher No. 7 , being for the boarding of George Washington, John Pililien and Henry Coffer, natives of the Sandwich Islands $c^{\text {is }}$ rejectedj..., as the men were not Arerican Seamen and therefore not entitied to relief."

By this time, however, the Hawaiian government was taking steps to provide its ow foreign consils. On August 25, 1848, official instrictions for such consuls were adopted in the Islands. These instructions forbade consuls from protecting Yewailan subjects who had committed crimes, anc from issujng passports to anyone known to be a deserter, arunkard, gambler, or of bad character in seneral. In cases where Hawaiian subjects djed intestate, the consul was to take an inventory of his goods anc dispose of them by public auction, but the consul. was forbidden to interfere with the local government's jurisoiction over land or other immovabie property of Kanakas. The instructions also provicied for the payment of salvage charges in case of wrecked Hawailar vessels, ana "In cases where Hawailan subjects complain to the Consul of wages withheld, the Consul [was] to

62 I bis., p. 353 .

$63 \mathrm{rol}$. III, p. 235, ibid.

64 tracts from instructions to diplomatic agents..., August 25,1848 . British Froreign office microfilm. 
employ his good offices with the employers..., and where justice is refused,...to recommend them courteously to the authorities of the country $[$ involved]...."

It was also as crewmen of a United States ship that Kanakas made a small contribution to an international incident in 1848-49. Fight Hawajians aboard the USS Lagoda, owned by Jonathan Bourne, Ir., of Massachusetts, joined in a desertion that took place off the coast of Japan on June 6, 1848. Fifteen crew members including the Kanakas left the ship in their whaleboats and landed near the straits of Matsmai. One of the Americans involved, John Brady, haó been reported previously as a runaway from the Iiverpool off the coast of Patagonia.

These deserters were imprisoned by the Japanese and fairly well treated until they escaped twice. Then the recaptured prisoners were forced to trample on a crucifix to prove they were not Catholic, and imprisoned in cages at Nagasaki with their feet in stocks, no fires or lights, and Iittle clotring. Cn December 17, one of the Kanakas, Maui, hung himself. The Japanese did not remove the body

65 Ibid.

66 ibia.

67U. E. Congress, Senate, s. Doc. 59, 32nd Cong., Ist sess. Uunathen Bourne, Ir., was the iather of Oregon's Senator Bourne. 68 The Friena, November I, 1848. 690 ctober 1., December 20, 1849, ibid. 
for two days and then would not allow the other crewmen to bury their dead companion. On January 24,1849 , one of the Americans, Ezra Goldthwaite, died. Goldthwaite had been treated by a Japanese physician, and the remaining crewmen later stated that they were sure foul play had caused his death. 70

In April, 1849, Commodore D. Geisinger, United States Naval Commander in the Eest Indies, sent Commancer James Glynn and his ship preble to effect the rescue of the deserters. Glynn spent two weeks at Nagasaki ar巳uing with Japanese officers and Iocal officials before the prisoners were released. 71 The rescued seamen claimed they had cieserted because of harsh treatment. The incident was invest1gated by the U. S. Congress but no apparent punitive action was taken. Depositions on their treatment or reasons for leaving their ship were not talen frcm the Hawaiians involved. 72

Seagoing Kanakas, however, eventually learned to demand their rights according to the current maritime practices. In 1850 , severteen Islenders sought court redress from the owner of the Eritish schooner Enigma. The Kanakas claimed danages for privations suffered aboard the schooner during a voyace to Hong Kong. They were forced to sleep on

$$
\begin{aligned}
& \text { 70ctober 1, 1849, ibid. } \\
& 71 \text { cotober } 1 \text { and jecember } 20 \text {, 1849, ibid. } \\
& 72 \text { ense te nocumt } 59 \text {, ibid. }
\end{aligned}
$$


deck, given little water, and only 45 days' rations for a voyage that lasted 63 days. $\quad$ ss a result four of their. number died. The British court ruled that the maritime act had been violated and awarded a $\$ 2000$ settlement. $^{74}$ Just a year later the death of a Kanaka aboard the British ship Pekin was thorcughly investigated in an English court. 75 The treatment of seamen was under attack at this period, and many governments were re-evaluating the long standing maritime codes. It is significant that kanakas were included in the reappraisal since it indicates to whet extent their numbers and abilities were appreciated.

Numerous instances have been recorded of the maritime skills of Kanakas being praised by sea captains or other persons, of which the following is only one example. A. J. Wing, captain of the whaleship Canton, reported beirg shipwrecked in 1854 . The survivors managed to reach an island but it had no water or vegetation. Fortunately, according to Wing, "... by the assistance of an expert Kanaka swimmer s some of the crew] were enabled to communicate through the rough seas with the wreck, from which they saved a quantity of bread anc other provisions." 76

The dering Kanakas were not frightened away from their seafuring litrelihoods even by the threat of beccming involved

$$
\begin{aligned}
& 73 \text { ine Friend, October 15, } 1850 \text {. } \\
& 7{ }^{4} \text { Ibia. } \\
& 75 \text { septerber 1, 1853, ibia. }
\end{aligned}
$$


In the American Civil War. One of the Island newspapers mentioned as early as 1863 that Islanders had taken sides in the conflict, ${ }^{77}$ and in september, 1865, this same paper reported several Kanakas had become captives aboard the Confederate pirate ship C.S. S. Shenandoah which was attacking Union whalers. The captain of the Shenandoah, Janes I. Waddell, captured and burced trese vessels after presenting crews with the ultimatum of jolning him or being marconed. Some fifty Kanakas finally were returned to the Is]ands by Waddell who reported to have heen "...rather partial to Hawaiians...." 78

The Russian-American Company aiso employed Fanaka seamen and laborers. The Company, first chartered in 1799, was under the complete control of the Russian government who wanted to expand in the Pacific, and since the Company colonies in Alaska could not support themselves, the government expressed interest in California as early as the 1790's. For the same reasons Company efforts were made in the Hawaitan Islanàs but American influence with Kamehameha made Russian control impossible.

By 1811 Russian interests in the Pacific had concentrated in Aaska and northern California. Fifteen

$$
\begin{aligned}
& 75 \text { iarch } 1,1855 \text {, ibjd. }
\end{aligned}
$$

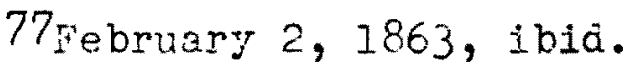

$$
\begin{aligned}
& 78 \text { september } 1,1865 \text {, ibid. } \\
& 79 \mathrm{~s} \text {. B. Oiun, The Pussian-Ameriean Company (Cambrige: } \\
& \text { Harvare inversity press, } 1951) \text {, pp. 50, } 94 \text {. Perefifer cited } \\
& \text { as Okun, Rusian-Anerican Company. }
\end{aligned}
$$


settlements were established in the northerr continent and adjacent islands, while at Ross forty-nine Russians Jabored to produce sufficient grain and livestoch to feed the northern colonies. Ross settlement was one square mile in area protected on the seaward side by a 70-foot precipice. Employees' quarters were located half-way between the fort and Bodega Eay, the Company's harbor. Buijdings incluaed a tannery, mill, workshops, sturercoms and a cattle shed. The Company continued efforts to expand in California even after investigations showed that Ross was only capabie of feocing itself, and after repeated complaints from the Spanish government denying the legality of the Russian colony in California and claiming non-payment of cuties.

Ross and all the Russian colonies faced a severe labor problem from the beginning of their existence compounded by the still prevalent system of seridom that existed in Russia. The dubious methods of the Company in accuiring settlers and seamen, and their treatrent after employee contracts were signed applied not only to fussian peasants but also to Alents, Inciians, and Kanakas in the Company's service. Since Alaskan natives were the most numerous and most vulnerable hovever, they sufferen most and complaints of their

80 chun, Russian-American Company, pp. 55, 134. Vain Office to Spanish tmosssacor de Zea Eermudez, Aupust, 1817 , Reccras of the Russian-American Company 1802 , 1817-1867, on microilim. Crefon Historical society. Hereafter cited as Mussien-Anerican Company microilin.

810 kun, Russian-American Company, pe, 123,127,239. 
mistratment are recorded in Company correspondence as early as 1816 . There are numerous references to the high death rate among these people, the Company organized them into furced labcr gangs, and discouraged efforts to Christianize 84 them.

The Iabor shortage apparentIy was most severe aboard the Company vessels used in transporting furs and supplies. The lack of cualified crews resulted in sixteen shipwrecks, out of a total fieet of cniy 32 vessels. The adeptness of the Kanakas as seamen made the Islans a logical recriiting area for Comnany employees, and Hawaiians were early considered as replacements for Aleuts on the Alasian islands. 85

Conditions of employment could not have been attractive even assreganding the severe climate. All employees were at first sigaed up for seven years but 1 ter this vas extended to fcurteen years. Many were falsely recruited, paid by half-shares rather than by wages, and could not leave the colonies without permission of the government. Malingering resulted in loss of half of the annual salary which was 350 rublas in 1821 . The government charged a high

Q.yain Office to Gov. Gen. Leontie A. Hagemeister, August 12, 1819, Russiän-American Company microtilm.

$83 \mathrm{Gov}$. Cen. Ivan Dorisovich Pestel to Minister of Interjor Kczoriavev, March 31, Ifl6, ibid.

$8+$ kon, pussien-American Comany, pp. $204,211$.

85okun, Pussiar-hmenican Comrery, p. 99. Nain office to cov. Gen. ileksande Anarevich Baranov, March 22, 1817; Main orfice to Haremeister, lenusry 6,1823 , ibid. 
fee for renewal of passports, required of all employees in America, but the oassports were renewed even when employees refused to give their written consent. 89 giance to the Russian czar was required, and the government supervised the issuance of clothing, medical and educational services. Employees who authorized allotments for their families did so for the duration of their employment; under no circumst nces could they later be decreased or terminated. Compeny monopoly of supplies placed employees in a position not dissimilar to that of miners in early American company towns -- they were kept in debt to the Company for necessities and were forbiduen to leave the colonies so long as such $a$ debt existed. 91 The company corresporidence records only one instance in which Kanakas were given approval to 92 return to their Islancs, no approvals were included for natives, and the very few for Russian peasants indicate the permission was granted so the government vould not have the responsibility of dependent families.

${ }^{86}$ okun, Russian-srerican Company, pp. 171-73.

87 orun, Bussien-American Company, pp. 176-7. Vain of ice to Gov. Gen. Satvei Irrnovich Muraviev, March 8, 1.82j, hiveian-American Company microfilm.

Q8. ein Office to Muraviev, Jcunuary 15, 1820, and March 15, 2821 , ibia.

89 Mart ofice to mraviev, May 20,1820 , and Pebruary 27,1827, ibid.

90 Kain Office to Mravier, March 24,1826 ; January 20 , 1820; to Gov. Gen. Fetr Bgrovich Christiakow, March 31, 1827. 
Under such working conditions it is not surprising that labor shortage and desertion continued to plague the Company, or that repeated recinests that census information be supplied the Russian government were ignored. 93 The Company had good reason to avoid complying with such requests but, as a result, little reliable data on numbers of employees is available. In 1833 the population at Ross was reported as 199 of which only 41 were Russian, and in 1843 at least four Kanakas vere engaged for the Kemchatka labor force. In 1851 the population of all the Russian-American colonies was given as 9,273, including 1,070 Kanakas. Any additional fjgures were either never reported or destroyed later by the Company. 95

But regardless of the number of Kanakas who served the Russian-American Compary or American and f̂creign merchant

91 Main Office to Christiakov, ibid.; Main office to Muraviev, March 27, 1825, ibid.

92 Main office to Wuraviev, Warch 27,1825 , ibiä.

93orun, Russian-American Company, p. 204. Yain Office to Christiakov, karch 3I, 1827, Jussian-American Ccmpany microtilita.

94 okin, Fussian-Americari Company, pp. 140-44. Greer, "wincerins Kamaiiras," 222. "Ietters of A. Rotchev, last Comnerdant at fort Ross,..." tr. anc intro. by Prederick C. Coroes, Ca? forria Histcrical Dociety guarterly, YXXIX (June, $1960), 109$.

95 Both S. B. Oun and Raymond H. Pisher, author of the White to Dueshan microfilm records, report that Company records in st. Potursburg have never been found and are presumed cestroyed. 
and whaling vesse]s, or the increasing number of privately owned businesses in the Pacific Northwest and California, the fact remains that the IsJanders were everywhere evident and expanding their horizons and abilities. They were continuing to function as a part of the available labor force, and to craw cemands upon their various skills. But as the Uniteù States expanded to the Pacific Dcean and foreign competition dwinded or was completely eljminated, the economic picture changed and Kanalia fortunes began to decline. The first indication of future econcmic reversai for the Islanders came in 1848 when gold was discovered in California. 


\section{CHAPTER V}

\section{KANAKA GOLD FEVER}

When Johann Ausustus sutter reached California in 1839 he immediately presented himsel: before the Mexican governor, wian Alvarado, and convinced the governor to sell him a larga amount of land north of San rancisco on the American River. ${ }^{1}$ At the same time sutter informed Alvarado that he had brought with him a labor force that corisisted of "...5 wite ren and 8 vanacas csic, (two of them married)! Sutter prosoered by selifig supplies to arriving emigrants, either fron Cregon or the East, by selline livestock and proâce to Californians, and by trapping furs inder the very noses of $\triangle B C$ traders until he bought the Ross fort and surrounaing acreage in December, 1841, a punchase that effectively limited $\mathrm{HBC}$ activities in the area thereafter. 3 The province of Califorria meanwhile was becoming a great attraction to Americans, for its harbers at Vonterey and San Diego were regular stopovers for whalers and mercant vessels, ano sutter had every intention to

\section{Irohn A. Sutter, the Jiary of rohann Austus sutter} (San Francisco: Grabborn Press, 1932), p. 3 .

\section{EIbic.}

3Tone E. Harkness, "jhe HPC Enterprises in California"; oregon Historical Society MS. 728. 
continue growing with California. He urged the Monterey government to end its relationships with the $\mathrm{HBC}$ and mediled in local political splits favoring the side he considered most likely to gajn control. The HBC finally did decide to sell all its properties in California in 1846, but sitter was not successful in obtaining political alignments with the Arrericans.

The foreign population in California, centered in San Francisco, was growing rapidy, and by June, 1847,375 whites had located there in adcition to forty lianakes and ter Megroes. This population included few women (only one of the Islamoers was a woman) and $4 / 5$ 's of it was uncier the age of 40. The Kanakas and Negroes" ". formed nearly onefifth of the population, and, were motly employed as servants and prters. Wany of the sanowich islanders were engaged in navigating the bay, ard were very expert boatmen." one of the whites counted as a member of the san Franciscc population was James H. Wilbur, a Methodist minister who eventually traveled to. Oregon and becarre part of the stasf at willamette Institute. At the time he lived in 4 ranes A. Eorbes to Eustace Barron, January $27,1845$. Eritish Foreign Office microriim.

5 ibjo.

6soulé, Annajs or San Francisco, op. 176-8.

7 Ibid.

9 Ioid. 
San Francisco he ccunted only 260 howses with most of the population living in tents or shanties. 10 He organized a Sabbath school and instructed a class of five Kanakas who Nilbur considered to be "...remarkably smart and apt to learn. Je etaughty 3 of them the Aiphabet so they [knew] every letter durins the School []$^{\prime \prime}$

Meanwile sutter had decided to buila a grist mill on the American River to adc another facet to his growing em12

pire. Norters at the mili discoverea gold and it was not long before this exciting news had reached oregon and ail of the inited states east of the Yississippi. The laboring classes of San Francisco were amone the first to desert their positions and head for the American River. ${ }^{13}$ This first rush inciuded Incians, lexicans from Sonora, California Kanakes, anc setilers from oregon, the latter also including ranakas.

The aiscovery of gola changed the pittern of California grovth and, in particulaí, the situation of its laboring classes. Vages rose to $\$ 12$ to $\$ 30$ a day, and jobs stili

9 Vares It. Nur cournal. Crecon Historical Scciety MS. 98 on microfin.

$$
\begin{aligned}
& 10 \mathrm{Tbia} \text {. } \\
& \text { II Iria. } \\
& 12 \text { Sovlé, Annals of San Francisco, p. } 133 \text {. } \\
& \text { İbia., p. } 209 \text {. } \\
& \text { I.t E.ti., r. 133. MS. } 803 \text {. }
\end{aligned}
$$




\section{5}

went begging. In Cregon and other surrounding areas mechanics, farmers, merchants, doctors, and ministers started for the gola fielcis by the thousands. 16 They left profitabie businesses, sacrî́icea property, anä paid high prices for mining supplies without a second thought. Soldiers deserted and crews jumped ship once they reached San Francisco 17 Bay.

Neny also began leaving the Islands for the gold fields. Some wrote back that all the gold stories were true and opportunities were excellent even if the Islanciers decided not to mine. ${ }^{18} \$ 200$ a month had been offered cre man to tale charge of a ship, while anyone could $: 0 t$ a day for labor ashore. Some reported that \$10-\$20 a dey was made digsing but this estimate might jump to as high as 500 19 a day.

Other. Islanders, however, soon discovered the hardslips involved -- the difficult labor, cola weather, and much 20 sickress. Kanakas returned from the Sacramento River with fever and ague, but not gold, and they were quick to suggest that those in the Islands stay there and avoid the unrewarding hardships and the extrenely high prices that included

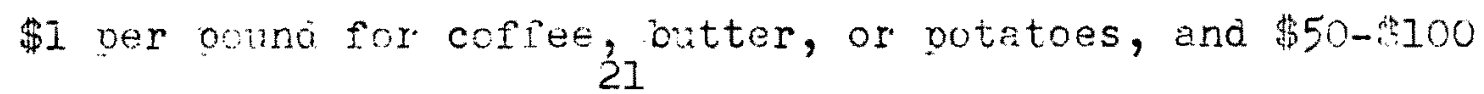
for one woolen blanket.

15 Sonté, Annais of San Frencisco, p. 215. 16"Atirinson Liary," 361. 17"Atkinson Diary," ibid. Sutter's Diary, f. 50. 
California was indeed boowing. Its population increased by 15,000 during the first six months of 1849 , and by the end of the year some 40,000 peopie had landed at San Francisco while another 3,000-4,000 seamen deserted. Wages continued to rise and property values soared. Land worth 15 in 1847 had risen to $\$ 400$ in 1848 , and to $\$ 10,000$ by 1849.23 The population was swollen by large numbers of Chin se and Mexicans who mingled on San Prancisco streets with "bad-smelling" legroes and "hanäome" Kanakas.

The Islanders at the mining areas had litt?e success and experienced difficulties with other miners because of their unorthodox methoas. The Kanalias were so adept as swimmers and divers that they could effectively scour the river bottoms for gold. American miners did not appreciate such methocs because they were not capable of performing such feats themselves. Along the American River, for instance, Kanakas worked an area some 50 yards long and 15 feet deep. The Kanakas here filled empty kegs with rocks and then attached the kegs to ropes. The kegs were sunk at likely

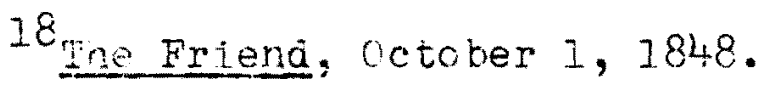

$$
\begin{aligned}
& 19 \text { Movember } 1,1848 \text {, ibid. } \\
& 20 \text { rbia. } \\
& 21_{\text {Ibici. }} \\
& 22 \text { Scuié, Annazs of Sen Prancisco, pp. } 243-44 \text {. } \\
& \text { 23he Erienc, November 1, } 1848 \text {. } \\
& { }^{24} \text { Soulé, Annajs of San Francisco, p. } 258 .
\end{aligned}
$$


spots and then the Islancers dove into the water to shovel sand from the bottom of the river into the kegs. ${ }^{26}$ After the kegs were hauled up the sand was washed in cradies to serarate out the gold.

Kánalas also settled along rivers in Sierra, Trinity, El Dorado, and Stanislaus counties. There were eight Islanders at Verona and another forty at Ia Grange. The Hawaitan comrunity at Indian Creek was led by lienao and included twerty-four Kanalas, two Jawaian women, and several Digger Indien women. Those at Indian Creek were considered Christiuns -- Derhaps five of their number hed previous?y attended the Rev. Nilbur's Sunajay school. Fenao lived in a painted clapboard house he had built. The Digrer womer had been taught to speak Fawailan, could read the flawaijan Bible, and were extremely neat housewives. 29 All of those at Incian Creek contributed funcs to build a commaity church ard to support a foreign missionary. 30 some of the Kanatas without their families sent gold dust bacle to the Islands for their support. 31 infortunately, in 1862, smallpox claimed

${ }^{25}$ C. W. Haskins, The Arronalits of Caifornia (New York: Fords, Howerd \& Hulbert, 1890), pp. 77-78.

26 Ibio.

27 Ibid.

28 achara $\mathrm{H}$. Dilzon, "Kanalia Cclonies in California,"

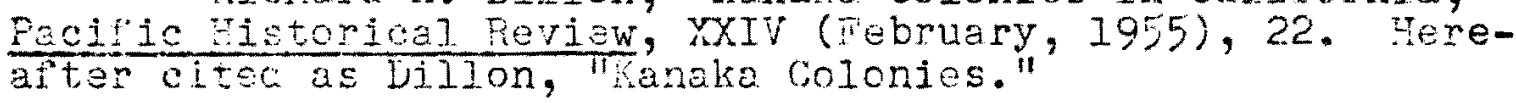
29 Alta CaIfrornia, May $24,1862$. 
the lives of several of these Islanders, including Kenao and his stepson. 32

In 1849 , the Rev. Damon, who as mentioned published The Friend newspaper in Honolulu and operated the Seamen's Chapel. there, decided to visit California wile on the Northwest coast. $^{33}$ After reaching san Prancisco, he set out with the superintendent of Methodist Missions to visit the various Kanaka settlements. He was eager to find old friends but since "...there had been much difficulty between Americans and forelgners at other places, che was also, desirous of cautioning the Hawaiians to be ppon their guard and not to give offence to the Americans." ${ }^{34}$ Those Damon spcke to listened calefully and asked "sensible" questions. 35

Damon received about twenty letters to deliver in the Islancis for the Ranalias, and was received warnly wherever he went. At one settlement he found an American lawyer selIing the Kanalas Iiquor, ${ }^{36}$ but Damon later reported that he had been "...glad to learn that a majority of the Yawaiians $30_{\text {Ibid. }}$ $31_{\text {rine }}$ Friend, February 2, 1863. 32 Alta Califcrnia, ibia.

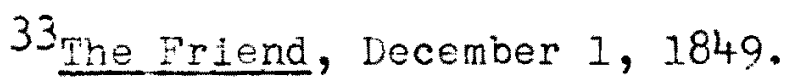
34 Ibid. 35 Ibia. ${ }^{36}$ Tbid. 
"were true to their tee-total principles, while those who were seauced had been long upon the coast and away from missionary influence!" ${ }^{37}$ Damon was certain many met regularly for Sunday services conducted by members of their own group. 38

Many of the old friends Damon alscovered digging for gold had previously been seamen. Seamen's wages had jumped to 200 a month and officer's' wages even higher, yet he found that few seamen were wiliing to rejoin ships even at rates of $\$ 1000$ for seamen on vessels sailing for the United states. 39 The magnetism of the rold fields was reflected in the number of vessels stranded in San Francisco's harbor in October, 1851. 232 were Amerjcan, 36 British, and 11 French. Ancther 148, apparently completely abandoned, had been run aground to serve as store builiings. San Franciscc's population had climbed to 25,000 (California had 264,435) and the poor living conditions resulted in a cholera epideric. The number of burials exceeded 4800 by the eno of 1354 , while before 1850 tre total burials had been less then 1000 .

$$
\begin{aligned}
& 37 \text { rbid. } \\
& 38_{\text {Ibid. }} \\
& 39_{\text {Ibid. }} \\
& 40_{\text {Souié, Annals of Sar Francisco: }} \cdot 355 . \\
& 4 i_{\text {Ibio., po. } 594-6 .}
\end{aligned}
$$


The foreign immigration, particularly of Chinese, was still high, and it was only the Chinese who were considered discrderly and undesirable. This disike of the Chinese developed into a strong prejudice that spread to Mexicans, Peruvians, Chileans, and finally to the Kanakas, because as forelgners they threatened American dominance in the gold fields. Increasing demands were thus rade to have them barred from the nines. 43 In 1850 the California legislature passed a law requiring foreigners to pay $\$ 20$ per month for the privilege of mining. Such a fee mede it impossible for many to continue mining since this amount might not be dug in a month. The few who remained merely were denied permission to use the permit issued with payment of the fee. Such was the case when Captain Coxe attempted to mine under a permit he had legally purchased on the American Riven.

Kanakas were no longer welcome in the gold fields, but when they attempted to return to other labor fields, they also found they were facing discrimination that had at first been leveled at the Chinese. The California Senete had passed an act calling for "Exclusion, specifically of 'Chinese or Kanaka carpenters, masons, or blacksmiths, brought here in swarms under contracts to compete with our own

42 Ibid., p. 368.
4 3 mhe Friend, December $1,1849$.
4 IDillon, "Kanaka Colonies," 18. leader on the fmerican River and was perhaps John Coxe of the HEC. 
"mechanics, whose labor is honorable, and as well entitled to social and political rights as the pursuits designated' learned professions." " Still, many of the Islanders refused to return to their homeland. In 1860,138 of them were still in California. of those who left many merely Followed the trail or gold to British Canada where a rush haj beeun April 25, 1858, and later moved on to Oregon. In Victoria the same probiems faced the permanent Anhabitant, even if to a lesser degree, as had almost overwhelmad San Francisco. The town "...swarmed with open latrines, tents, lean-to's, regroes, Kanakas, Chinese, rews, Frenchmen... who congregated lite birds of a feather...the jews on Johnson Street, the Chinese in nearby Iittle Canton, the Kanakas on Kanaka kow [now Humboldt street) and the negroes wherever they could find room."

The gold rush in the klamath river area in Cregon began in 1870, and many Hawailans migrated to that area to operate placer mines. At the height of the rush approximately one hundred were located along various creeks and one tawailan mine remained in operation until 1885 . There

45 . S. Congress, Serate, 50th Cong., lst sess., Coripressional Record, p. 8225.

46 paul S. Tayloi", "Foundations of California Rural Society," Ce ifornia Historical Society Quarterly, XXIV (Septerber, 1945 ), 340 .

4 ? Gregson, Victoria, p. 12.

Libio., p. 13 . 
was a Kanaka school and cemetery at rilamath River and President Herbert Hoover visited the former during a fishing trip. 50

Some of the 138 Kanakas who did not leave California. began missionary work with the Digger Indians, considered the lowest of Indian groups because of their wandering habits and low social structure. No church had bothered to considier their salvation, but the Islanders moved into their midst, taught them new skills, and even intermarried with them. One of these Iiggers, John Yakanj, was sent to the Islands for religious training by the "awailan Missionary Board and later returred to California to teach and Christianize his trike. ${ }^{52}$ But the Diggers were doomed as surely as cther California Indian groups before them, and Kanalyas who were themsejves facing discrimination in this area could do little to protect their Incian charges.

As the American nation began looking toward the begirning of a new century, citizens of the western United. States were just beginning to realize their full economic and political potentials. Growth in the west, however, began with immigration from the East anc thjs movement

49,kedford Mail Iribune, March 22, 1967.

50 Ibia.

51 The Friend, December $1,1849$.

5 Dijon, "Kanala Colonies," 21. 
westward embodied a spread and accentuation of white superjortty principles. The Chinese in California were the first to experience the impiications of this doctrine because at the time of the gold rush they were the most numerous and most foreign in their sccial habits. What started with the Orjentals, however, cuickly spread to threaten members of the Hawailan nation, not because, as has been indicated, the Kanakas were disorierly or urchristian in their social structure, or unwilling to work equally as hard as the Americans. The reason was simp?y because they were not white and such a prejudicial outlook was incapable of discriminatory application. California was only the beginning to the racial struggle facing Kangkas in the Nest. What the gold rush of 1849 initiated, the political turmoils of the last decades of the nineteenth century completed. 


\section{CHAPTER VI}

\section{POLITICAL DEFEAT}

The mid-nineteenth century was a period of considerable political upheaval throughont the linited states, in the Fawailan Islands, and in Great Britain. The British, embodied in the HBC, anc Americans had disputed for thirty years the boundary and possessory rights in the oregon country. $^{1}$ As the numbers of American settlers jncreased along the Columbia River, their demand for a settlement of the dispute and protection under the American flag increased. At the same time Englichmen were beginning to question the rightness of monopoly as represented by the HBC, and the Company itself had reachea the conelusion that the profitability of the Cregon country was rapidily disappesing. As John Mcloughlin had earlier realized, it had been inpossible to stop the American immigrant tide and so he had supported them economically ana cocperated in the estabishment or the cregon Provisional government in $1843^{3}$

Irenerick Merk, The Cregor rustion (Cambridge: Horvarc Tniveasty Press, 1967), p. x.

2 Ibid., pp. 23t-254;309-336.

30 eron Arohives; incl idne the rounnels, covernors'

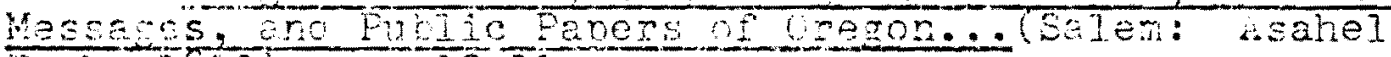
Bush, 16,3), 20. 12-13. 
Unfortunately, Mcloughlin's cooperation had not eliminated the antagonism that existed between the Americans and British subjects, and by the time the Oregon question was settled in 1846 the British subject or employee had become a focal point for intense djslike and discrimination. This antagonism was an important factor in the political organization that led to the establjshment of Oregon Territory in 1848 . 1848 was also the year that the united States and Mexican governments concluded the Treaty of Guadalupe Hialgo ending the Mexican Nar. This treaty and the boundary settlement in Oregon adced $1,2000,000$ square miles to the American territory, incluoing the rest of lexas, ano all of New Mexico and California. The tnited States had extended itself to the Pacific fulfilling its "Manifest Destiny" and creating a continental democracy. Expansion, however, also wold scon increase the problems relatec to sectionalism within the United States. It was al ready evident that the young democracy was moving inexorably toward an internal conflict over states' rights and slavery. The opposing forces that woulc clash over the issue of Mesco suffrage manifested sereral adjitional social phenoman that inflicnced the political characteristics of the orescn country in 2848 . Whether or not it is true that recial prejudice became more pronounced as the American

4 Ray AIEn Eillington, Hestward Expansion: A History of the American prontier (Thisd Wh.; Lew York: The Macmilin Company, ito7), pp. 586-8\% 
nation expanded westward, the fact remains that such prejudices were exhibited in Oregon against Negroes, Kanakas, Indians, and the Chirese. No distinction was made among any of these groups -- all were inferior because none were white. Similarly, anti-Catholicism was rampant, not only because of the prominence of the Frotestant missjons in oregon, but also because a similar movement soon would biossom east of the Rockies in the Know-Nothine Party. Oregon politics and political leaders, therefore, were only mirrors of Eastern thought during the seme period, with only minor variations to accommodate social differences. Easterners, for the most part, were unfariliar with Indians unexposed to American civilization, but the menace of those in the Northwest was exploited after the Whitman Massacwe.

Iand was of paramount importance to all Americans regardjess of their location, and the demand for its effective exploitation for the benefit of white Americans increased racial problems. Americans believed that land owership meant prosperity, social acceptance, and indiviutulity. Iand was nationalisn, democracy, and equaitit at the polis and the man who owned land and tilled the soil was a syrobl of respect, the American dream, and a blossoming agrarian myth. HErarianism enconpassed racial

5 Hchara Hof stadter, The Age of Reform: From Bryan to.n. We Work: Random House, 1955), pp. 70-7\%. Sy $+10: 2$ QLlington, The Protestant Crusade 1800-1860 (Cinisuo: Oudranzle Books, 1964), p. $23^{4}$. 
prejudice -- toward the Indian because he did not accept the symbol or the dream, and toward Negroes, Kanakas, and Chinese because lanả acquisition for them meant less land available for whites to control and exploit. The obvious solution was to deny minorities consideration under the various T. S. land acts and this policy, in turn, furthered prejudicial social, political, and economic behavior on the part of a white, Protestant majority.

The Islands also were facing problems of expansion and nationhood. The population still was threatened by diseace and loss of its young men tc poreign merchant vessels and labor markets. Kamehameha III and his advisors were making procress toward establishing a democratic form of government but outside influences were becoming increasingly difficult to control or suborinate. Arerican observans were expressing a fear that the tawailan government would "...soon be in cthej hands of Foreigners." It was not so mich annexation by a foreign government that was feared, however, as of "...white Kanakas. cwhoj will work the Rightful owners and proprietors of the sovereisnty out of place, power, and interest and everything belonging to the aboritinaz!"

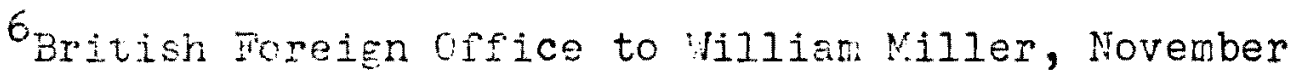
15. 1853. Jitish Foreign Office microfizm.

7 arian papers, Vol. $V$, p. 80 .

80 
Americans, of course, saw only British usurpers among these white Kanakas, and Stephen Reynolds, of Honolulu, was hopeful that the United States would serd a new consul and comissioner to the Islands to do some "...taming among the Heathen-ish white skin-Kanakas." The British placed the blame on Americans who, the British Consul claimed, had framed the Constitution and laws of the Island kingdom, airected ail Church affairs, and controiled the King, his chiefs, and aIl the Islanders. Even the juajcial system had Americans serving as jurors although at least a portion of the judges were natives. Icri iberdeen, Britain's foreign minister, was very much aware of the bitter feeiing in the Islands between Americans and Englishmen, but he wrote his tavaian consul that England could not combat the American influence openly, but should rather work to reverse 11

native opinions. Such persuasion was not easy in view of the previous British forced landing on the Islancs and of Charlton's successful land grab. But Americans had displayed thoir zreed too and many United states ship owners, as well as British merchents, were suspected of purchasing vesseis in the Islund area simp?y to claim the sight, according to Fiawaian idu, to register such vesse]s as Hawailan and thereby atrota payment of ail harbor dues.

901. IV, po. 197-98, ibid.

10. Eritish Foreigr Office microfiim. 
There vere also many on the United States mainland, Including Samiel R. Thurston, Oregon's Congressional representative, who openly advocated American control of Hawaif, and in a letter published in the salem spectator Thurston amoniched his constituents to "...keen an eye to the sandwish Islands. Fate has written the destiny of the natives of those Is]ancs, and the New Thgland of the Facific foregonj must and should male and write the future history of the Islands themselves... The North American continent, with the Islands of the seas, is ours by the gift of God." Thurston's Arerican arean did not stop at the Pacific coast and his actions in ostracizing ranakas from oregon and in keeping them from participating in the political and economic future of that area refiact an expansionistic attitude nearly half a century before the spanish-Arcerican War.

Foreign intrigue for Hawaian favor was observed not only by Rarnehameha III and his advisors, but by $r_{1}$ is subjects as well whose uneasiness resulteo in a petition acdressed to the king, August 1, 1845, asking for the dismissal of all foreigrers serving as hawaijan ofticials, whorawal of citizenship for foreigners, and cessation of II Ibid. 12rohn Ricord to G. P. Judd, october 7, 1844, ibia. 13 coupon Soectator, fune $27, .7850$. 
land sales to any non-llawaitans. Approximately 1600 petitioners stated that since the United States, Great Britain, France, and Beluim had all agreed the Islands were independent, "...therefore it is very clear tc us, that it is not proper that any foreigner should come in and be prowoted in your kingâm, among your chiefs, and your people." 15

To the king and his advisors, however, the problems of administering the Island government withut the assistance of foreigners was, at least fon the present, ost of the ouestion since these outsiders were the cres wj.th tive capital and qualifications necessary to carry on the econonic affirs so vital to the isiancs. Whe ling therefore replied to the petition by citing the advisability of allowing foreigners to become tawailan citizens since those so accepted could not only be protected by the ies but conld aIso be subject to its punishment. And "... If his hajesty thinks it expedient to sell lands to his cwn people, is it proper for him to refuse another, who has forsaken the land of his birth, and his first chief, and become a thawaian subject? by no means, for this would be using partiality." Such wes the sence of justice expressed and practiced by the ruter of a people consiciered to be heathenish,

$$
\begin{aligned}
& 14^{1} \text { he Priend, August } 1,1845 . \\
& 15 \text { bia. } \\
& 16 \text { ria. }
\end{aligned}
$$


backward, and racially inferior by many Englishmen and Amerlcans. And such was the political situation in the Pacific Northwest and, indeed in all of the United States, that this conviction expressed by a recently Christianized. savage can be cited as one of the few statements embodying true Christian principies in the treatment of races equaliy upon their merits alone. As shown above, the Kanakas in California found themselves equated with the Chinese not because they were disorderly as the Chinese vere ccnsibered, nor because their numbers threatened white superiority as the mass Chinese emigration appenred to nave done. Whe association was apparently only through skin color for that which was not white was inferior.

The growth of discrimination asainst Fanakas in the newiy created oregon Territory was more complex but the 17 foundation was the same. Certanly the labor demand had not lessened for one of oregon's most resuected citizens stated erphotically that "...labor of any kind is more valuable rin Oregong than in any of the states." ${ }^{18}$ the numbers of the Is]anders had declined durins the California soid mun, sore had gone to the Victoria mines, and many others hed folloved the Huson's Bay Company's withdrawal 19 to the north. The fanakas freantly had been praised

7oregon Territory was established Armust 3, 1848, and ind icec the resent, states of Idaho and Jashington. 15. 48.

16ettrey P. Deacy to Benjarin Simpson, July 28, 7857 , 
for their loyalty and diverse abilities and there is no evidence to suggest a sudien reversal or ciesertion of these qualities.

But the discrimination was there and growing in intensity as the oregon country organized itself politically and then moved toward statehood. In Cajifornia it had beon the Chinese problem that had engrifed the ranakas, but in the Northwest j.t was the introduction of the Negro ani growing antagonism over s]avery and Ianc acouisition that combined to eliminate Hawaian claims to equal rights under American law. The Negro problem was, however, only one manifestation of a racial bias that was part of American expansion and the protestant myth that only the white man was chosen of God to prosper ard conguer. This God-given right to transform the New World, to Christjanize and civilize the original inhabitants, was believed as strongly by New Englanu Purjtans as by their descendants who crossed the Mississippi River. The American Indians were the first to face this "rightous ceuse" and the first to retreat before its advance. 20 The Indian had no right to the Ianc he occupied because he did not exploit it. The white man therefore actec justly in taking jt from hin since the Incian who coula not and rould not adopt civilization

$$
\begin{aligned}
& { }^{19} \text { Gregson, Victorie, c. 12. NS. } 101 . \\
& \text { 20 Sralcing NS. 1201. }
\end{aligned}
$$


scon encugh to save some of the land for himself was only denonstrating another ranifestation of racjal inferiority. The Negroes shared the same label of inferiority and were treated in a similar manner when it came to a questicn of their rights to be free, to seek protection under the law, and to acquire property. Few, if any, Northern abolitionists could honestly aumit they wanted to accept the black man as an equal, or to give him ioentical property rights. The Mortherners with few excertions championed Negro rights in order to cposse the south whose representatives dominated the Congross, anc supported 21 state rights.

The Northwest entereu the political arena just as the American racial problen was becoming a major political question. In fact, many oregon settlers had cone from Missouri where the question of race relations had been especiaily proninent. It is therefore not surprising that the problem appeared early in cregon politics. Neither is it surprising that Kanalas were included in the attempts to ostracize politically inferior races. The tawajians were, after ail, "...as black as...Megroes of the south,", they vere identified with the hated HEC, and, inexcusabjy frot the white mon's vantare point, they had made known

2ic. Fan: Ncoward, The Strange Career of Jim Crow (Sacond Kevisea Edition; New York: Gxford Tniversity Press, 1956), po. $5,7,17-21$.

22:, S. Congress, House, 3lst Cong, Ist sess., May 28,1850, Conpessional Ciobe, 1075-80. 
their desire to become American citizens, to settle, vote, anci own property in oregon country.

\section{3}

In The, 1844, the Cregon Provisional Government passed an act regarding lard clains which stated "That no percon shall hold a claim uncer the provisions of this act except free males, over the age of elghteen, who would be entit?ed to vote if of lawful age..." ${ }^{24}$ the voting right a] ready had been restricted to free, white males. 25 Just six months later the Provisional. Iesislature enactea legislation requiring Nezroes, mulattos, and by implication Kanakis, to leave Oregon. If they did not do so, they would be subject to arrest ana trial ard, if found gnilty (as if there could be any question of this) they would be auctioned of publicly to any indivirual needing laborers, with the stjpulation that the said employer would remove his forced labor out of the area within six months after their period of labor ended. 27

To be certain that no misunderstancing existed as to where Karakas stood, the government singled them out for further legislation. At the December session, 1845, ar act

23we Frieno, october 1, 1849.

${ }^{24}$ Act on Iand Claims pessed Tune 25,1844 . Laws of a Gensea tne Iocal Natire passed by the Iegislative Assembiy, 105:- peafter cited as Cregon Iaws.

25 sifrice uncer the ordinance of 1787 was, by common consent, so limited.

t. An Amerciatory Act regarding Slavery, etc., December 19,1844, crogon Laws. 
was introduced stipulating "That all persons who shall hereafter introduce into Oregon Territory sob Sandwich Iszanders...for a term of Service shall pay a tax of five dol.lars for each person so introduced." An additional section of this bill called for an annual $\$ 3$ tax on persons al ready emoloying Kanakas and not returning them to the Islancs. 29

The discriminatory practices of the Provisional Government were echoed in the Craanic Act oreating Cregon Territory that was adopted by the U. $S$. Congress on August 3, 1848. 30 This act provided that the first gcvernor was to recuire that a census be taken of the oregon population for the purpose of deternining qualifjed voters to elect teritorial representatives and a Congressional delegate. Those qualified to vote were specificaliy stated as being white, male inhabitants, over 21 years of age, who were residents of the territory. 31 After the first election, however, Congress relinguished authority to determine voting qualifications to the oregon assembly, provides that said voters were still over 21 and either citizens of the

27 Ibid.

28 Provisional and Territorial Government microfilm, No. $163^{4}$, Oregon Historjeal Society.

29 Tbid.

30Teritorial papers, U. S. Senate, oregon, HR. \#39. Orezon Yistorical society on nicrofilm. Hereafter cited as orogen verritorial microsizm. 
United states, or inciviouals who had sworn an oath of intention to become citizens. 32

The 1849 census showed a population of 9083 in ten Oregon counties. ${ }^{33}$ By provision of the Organic Act this total could not include the numbers of Indians, half-breeds, or Hawaiians in the territory, and they were excluded from voting in the first election. Thereafter, however, the legislative assembly was empowered to set voting qualifications with the exception of age and citizenship. The Hawailans in the Territory were aware of this provision and therefore several appeared before the proper officers stating their desire to become United States citizens and thereby be privileged to vote in future elections. 35 Their request vas consiciered by the first territorial governor, Joseph Iane, but he evaded the responstbility of decision by referring the matter to William $P$. Bryant, the first appointed Supreme Court Judge of the Territory.

Bryant, unfortunately for the Kanakas, was not interested eithor in championing the rights of minorities

32 Ibid.

33 Tne Friend, October 1, 1849.

3).R. \#201, oregon territorial microfilm.

35 The Friend, ibid.

35 Ibid. The autror found no record of this petition in the Oregon Archives, Congressional documents, or the papers of Dryent and Lane. 
specifically, or in the new territory generally. Bryant certainly does not deserve remembrance for his action on the Kanaka vetition since he also managed to avoid the issue by expressing uncertainty about authorization under the existing United states laws. 37 The law was explicit, however, in denying citizenship to the African race and therefore, again obviously by implication, Bryant decided the Kanakas could not be allowed to acquire citizenship. 38

A comparison of the treatment received by the Kanakas, as foreigners in Oregon, with the statement and practice of the Haweiian government toward its foreigners supports a conclusion that these "Is]ard savages" had learned the principles of democratic government and equality under the law better than their teachers. 39 between Lawaii and the United States in 1849 only serves to clarify the disparity that existed between principles espoused by the United States government and those actualiy practiced. Under Article 8 of this treaty citizens of both countries were entitled to complete freedom of moverent, residence rights, and to equal taxation while residing in the other country. Such citizens also were "...free in the states of the other to manage their own affairs..."

37 mine Eriend, ibid.

38 itia.

39 me prienâa, August 1, 1845.

40 The Friend, September 1, 1850 . 
The disparity is obvious as the political situation in Oregon alone has shown. The Kanakas, or their employers, were not equally taxed, the movements of the Islanders were restricted, they were refused the right of citizenship through residence, and they could not purchase liquor or testify against whites in the courts.

Neither were they to be allowed to occupy property, real or personal, as an exanination of the writing, debate over, and passage of the Oregon Donaticn isct in the U. S. Congress will show. Samuel inurstor was elected by oregonians eligible to vote as their territorial representative to the Thirty-first Congress. He was dedicated to the cause of acquiring adeouate land donations for the oregon settiers if they were white, and unassociated with the $\mathrm{HBC}$. 43

As a first step toward passage of the Oregon Land Bill, Thurston introduced a resolution in the House of Representatives in May, 1850, requesting that the territorial ccmittee be instructed to gather ${ }_{4}^{i}$ formation on several points relating to oregon lands. First, the

$41_{\text {Ibiả. }}$

42Amencatory Act, December 19, 184h, Oregon Laws. Oregon Svertator, September 12, 1850 . creaon Etatesman, Decenber 27, 1853 . No. 1634 , Provisional and Territorial Geverntent microtilm.

43.5. Songress, Touse, May 28, 1850, ibid. 4tinid. 
present population of the area and the number of American citizens and forejgners should be determined. Secondly, Thurston wanted to know what inducements had been given to emigrants. Thirdy, the traveling time to the area, both by land and by sea shoula be considered. Finally, the justice of donating land to American citizens then in the territory and to all foreigners who would become citizens, and the rules that would govern donations made to native born and naturalized citizens, must be constructed.

By the middle of May the debate over wording of Oregon's land bill had begun in earrest and Thurston made the first of several determined efforts on behalf of exclusive white land ownership by proposing ar amendment "hith there shall be and hereby is granted to every white male sett]er or ccoupant of the public lands, American hajt-breeds included, members and servants of the Hudson's Bay anc Puget Sound Agricultural Company excepted $c,{ }^{\prime \prime}$ ? certain amount of land. Several fouse members immediately objectec and pointed out that two sets of requirements baseä urnn either present or future cccupancy was discriminatory. Tames Eowlin of Missouri spoke arainst reciaimIne property and ariving of former HEC erployees. ${ }^{4}$ To

$$
\begin{aligned}
& 45 \text { Ibia. } \\
& 46 \text { Ibid. } \\
& 4 \% \text { Ibid. }
\end{aligned}
$$


this latter objection Thurston referred the House members "...to the Supreme judge of our Territory, for proof that this $\mathrm{Dr}$. McLoughlin refuses to file his intention to become an American citizen." 48 Thurston, in attacking MicLoughtin, was protecting his political future by offering evidence that he supported the oregon missionaries, who were lccally powerful and almost unanimous in desiring the downfall of Mcloughlin. He knew at the time that Mcloughlin had made known his intentions to become an American citizen so his purpose was to use Mcloughlin as a shortcut to the true objects of his cetermination for discriminatcry land law action -- The iNegroes and Kanakas.

If, in fact, Thurston had cesired exclusicn of licLoughlin and/or his white employees, he would never have stated his willineness to accept a land law that donated land to foreigners willing to swear allegiance to the 49

Inited states. There was also a specific racial grouping implied in Thurston's references to the FeC because Indian employees were automatically eliminated, and the FrenchCaradians hod either been accepted by oregcnians, 50 or had returned to ked River settlement. 51 It is clear which

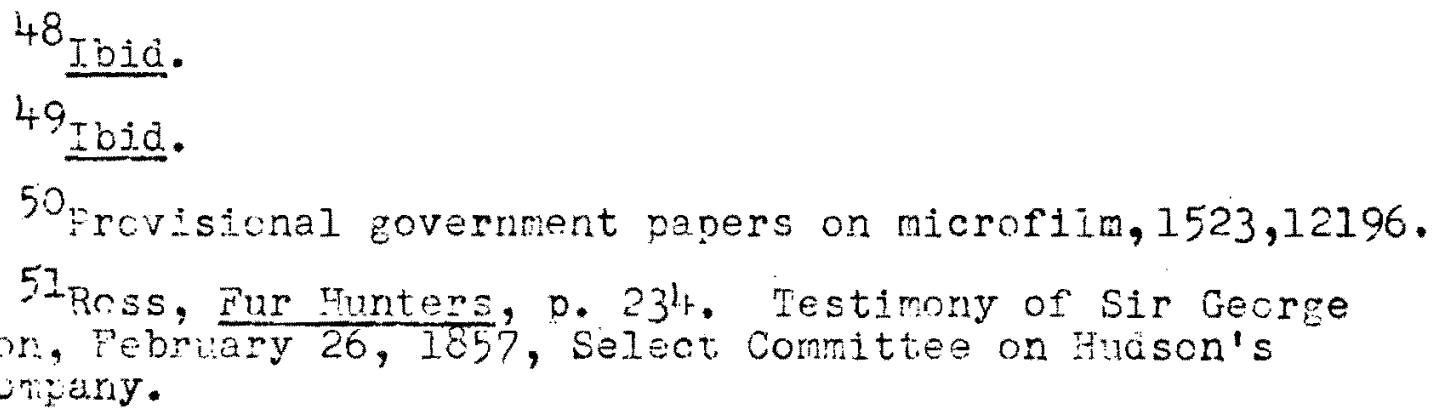


employees were left -- and it is also apparent that Thurston was doing nothing unusual in attacking the Negroes. There were no House members who spoke out against this discriminatory practice. AlI Thurston needed to show, then, was the connection between Islanders and Negroes who would, he statea, "...if allowed to come [ to oregonj,... commingle with our Indians, a mixed race cwould, ensue, and the result c wouldjbe wars and bloodshed in Cregon.", anä his statement that the Kanakas were of the sane shin color as the Negroes was calculated to present a picture of unmistakis]a similarity between the two races for Congressional mombers who had never seen an Hawaitan or had any exposture to their abilities ana attributes. 52

Thurston also expressed the opinion that if Negroes were allowed into the Territory they too would intermarry with local Indians, "... ana a mixed race wo'ld ensue inimical to the whites; and the Indians being led on by the Negro who is better acquainted with the customs, langnage, and manners of the whites, than the Indian, these savares would become much more formiable than they otherwice wovid, and long and blcody wars would result]..." 53 there is no doubt that Thurston fejt an inter-relationship between Kanakas and Indians would have the same result. Nor is

52. S. Congress, House, May 28, 1850, ibid.

53 rhurston to nembers of House of Represertatives, n.d., oregon HistoricaI Society MS. 379. 
there doubt that he had complete faith in the superiority of white blood since he expressed no fear of granting land and suffrage to half-breeds. 54 They were, after all, the offspring of early Oregon emigrants and chilcren "...of" our brethren,...all of them adherecd, to the whites," and their voting influence in Oregon required careful political manipulation by Trurston. 55

The Donation Act that passed assisted only the wite population ana reflected Thurston's success in obtaining Iegislation that would effectiveIy confine tanailas to their Islanas. Such restrictions did not, however, stop the confi.ict over land rights and equality under the law. In fact, there were some in Oregon who questioned the tactics, if not the results. G. L. Curry, for instance, expressed more concern with the need for encouraging population growth than the overindulgence of the present settiers. 56 The Iand act also led to a clash between Thurston ana Judge 0 . C. Pratt over the interpretation of the clause relating to the naturalization of forejgners (except Hawaiians) and their subeeduent eligibility to vote because Pratt had ruied that the Territorial Iegislature aid not have the right to rectrict voting, after the first election, to those foreigners who had completed the naturalization

$5+$ I.jia.

55 Ibid.

56 . J. Curry to S. R. Thurston, December $14,1850$. oregon Historical Society Ms. 700. 
57

orocess.

Thurston sharply attacked this ruling in a way

that indicated he was most interested in protecting the white, Protestant image. Clearly, wrote Thurston to Samuel Parker and Wesley Shannon, the law appliod to the first election only, otherwise, any Negro who acquired American citizenship would have the right thereafter to vote in Cregon. 58

Those who questionsd the provisions of the Donation Iand Act were accused of being supporters of the HBC and of desiring the political demise of Thurston. Cregon's congressional delegate also was careful to publicly nake known his contributions to Oregon's futwre, and to point out any errors or misquotations that appeared about the Act in oregon newspapers not his firm supporters.

Kanalias, therefore, found themselves excluded, by reason of a dark skin that tied them to the Iregro-American population rather than to the white, Anglo-Saxon one, from acquiring the rights of citizenship and the security of home and land. This discrimination embittered the lawaitans and made the return to their homeland appear more attractive.

570. C. Pratt to Semuel Parker, May 31, 1850. Oregon Histomical Society $\because 5.426$.

58 Ibid. Thurston to Samel parker and Nes?ey Shannon, dugust 31, 1850. Oregon Historical Society KS 379.

59 iesiey Shannon to Thurston, September 4, 1850, ibia. 60 Thurston to Asahel Bush, February 27, 1851, 1bid. 
Such a decision was more sensible than fighting a losing battle against discrimination and, although some did intermarry and lose their recial identity, many returned to the Islancs. There they continued to exhibit a sense of racial equaity that was apparent nowhere else in the world. This Christian behavior continued to puzzle their supposed teachers and white Americans who visited the Islands. The fact that all grades of racial mixtures, "...from the genuine wite to the unadulterated Kanaka...mingied together

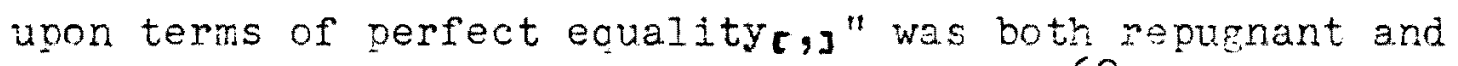
incomprehencible to many who witnessed it. ${ }^{62}$. Mot surprisingly these same people were the first to ignore Kandia contributions to the growth of t'e western part of the United states, and were the most consistent in labeling them uneducatec savages. This double stanara as applied to fmerican race relations has changed little in the last seventy-five years. Treatment of minorities is stili a problem in the United States, and the Kanaka contributions and historical importance is still largely ignored.

$6 I_{\text {rhe }}$ Frjend, August 1,1845 . M. 48.

$62 \mathrm{E}$. W. McGray to M. P. Deady, Lecember 24,1864 , 


\section{CHAPPER VII}

\section{CONCLUSIONS}

The Hawaians first came to the North smerican continent west of the Rockies as seamen, as adventurers, and as representatives of their hing. They were accepted as skilled sailors, courageous and hardworking laborers, and intelligent and loyal employees. Dinjng the first decades of the nineteenth century lanares won a respected place with the Hudson's Bay Company, helpod to build Astoria and to staff the establishments of Nathaniel wyeth, trapped and explored from the coast to the Roclies, north to Alaska and south into California, and represented an important and reliable labor force in the Northwest to fur trader, missionary, and early American settler.

Many Kanakas served the merchant vesse]s, whalers, and even warships of the contenders for control of the Pacific "orthwest -- the British, the Pussiars, and the Americans. Once again they proved themselves skillea seaAen, loyal and couragoous, enamoured of Christian ard denocratic principles. Never did they threaten to cverrun the American lest, seloom did any Kanara give cause for distrust or criminal prosecution.

In fact, by the latter haIf of the century, most Tanakes were involved in the various economic activities 
that made possible the rapid growth of the area west of the Rockies. They were producing lumber for expanding inaustry, guiding ships safely into varjous coastal harbors, or farming and herding livestock to satisfy food demanos of the area. In sum, these Kanakas hed becorne sedentary, semipermanent inhabitints, sgrarian in outlook, iust as American settiers first were preceded by explorers, trappers, and hunters tho paved the way for American farmers and businessmen.

Their early history gives sufficient evidence of the Kanakas' abilities to change, to adapt, and to adjust according to the prevaijine economic situation. It was therefore not surprising that the Islanders also sought personel wealth in the rold fields, or that they served diligentiy the religious faiths they adopted to achieve self-improvement. The personal sacrifices they made in the Utah cesent or in accepting Digger Indians as a missionary cause vere not unlike those made by earlier Kanakas in trapring through the wilderness or serving at isolated forts where weather and environment were totally alien to them. rhey were a strong and determined people, capable of inventiveness, wling to adapt in order to prosper.

But they were also a brown people who were not AngloSexon, and who orisinated in a foreign land. Once the Americans of the eastern half of the United States began moving across the rockies in large numbers, Kanakas faced a 
discrimination aimed at the Chinese, Indians, Jegroes, and themselves. The principle of white men's superiority and God-given right to exploit, legislate, and eliminate all minority races was not to be easily controlled and its strength grew as its adherents moved westward. The Kanakas wanted only equal rights -- to settle, to acquire land and sustenance, to raise a family, to continue to contribute to the growth and prosperity of their acopted country. What they received was almost total denial of such rights and opportunity. So the Kanakas returned to their Islands and by 1900 their presence in the area west of the Rockies could be associated with only a few scattered population areas.

What Kanakas might have contributed as United States citizens after 1900 can never be known, and what they achieved in Hawaii is another story. There is no doubt, however, that Kanaka contributions prior to the beginning of the twentietr century deserve careful consideration in the evaluation of the $\mathrm{ABC}$ influence upon future coastal growitin, in the stuay of the exploration and settlement of the area, and in the determination of factors that influenced econonic progress in the area west of the Rockies. 


\section{A SELECTED EIBLTOGPAPHY}

Manuscript Collections

Hudson's Bay Company Archives, London. MuLoughlin Papers, B. $223 / \mathrm{b} / 24$ fo. $5+\mathrm{d}$.

Oregon Iłistorical Society, Portland. A.B.C.P.M., MS. 1200. Oregon Historical Society. Thomas M. Anderson, MS. 495. Oregon Historical Society. Astoria MilIs ledger, MS. $979 B$. Oregon Historical Society. Herbert Beaver, MS. 372. Cregon Historical Society. Belknap MS. 91 and 92, The Grains, or Passages in the Life of Ruth Rover.

Oregon Historical Society. William P. Bryant, MS. 823. Oregon Historical Society. John Nason Colcord, MS. 234. Oregor Historical Society. Columbia River Fishing and Trading Company, MS. 938B.

Oregon Historical Society. Amos Cooke, MS. 1223.

Oregon Historical Society. Cowlitz Farm Employee Lists, AS. 135 .

Oregon Historical Society. G. L. Curry, MS. 700.

oregon Historical Society. Samuel C. Damon, MS. 803.

Oregon Historical Society. Matthew P. Deady, MS. 48.

Oregon Iristorical Society. Daniel Lee, MS. 1211.

Oregon Historical Society. Jason Lee, MS. 1212.

Oregen Historical Society. Dhilip Lehman, "The Religious, Noral, and Educationaj. Activities of the Hudson's Bay Comeny," MS. 729.

Oregon Historical Society. Methodist Missions, MS. 1224. tregon Historical Society. Samuel Parker, MS. 1206. 
Oregon Historical Society. O. C. Pratt, MS. 426.

Oregon Historical Society. A. B. Smith, MS. 1205.

Oregon Historical Society. Henry Spaläing, MS. 1201.

Oregon Historical Society. S. R. Thurston, NS. 379.

Oregon Historical Society. Alvan Waller, MS. 2210.

Oregon Historical Society. Henry James Warre, MS. 47.

Oregon Historical Society. James H. Wilbur, MS. 98 on microfilm.

Oregon Historical Society. Marcus Whitman, MS. 1203.

Oregon Historical Society. John Work, MS. 319.

Oregon Historical Society. Nathaniel J. Wyeth, MS. 1198.

Public Documents

Great Britoin. Parliament. House of Commons. Select Committee on the Hudson's Bay Company. Orderec by the House of Commons, to be printed, 31 July and 11 August 1857 .

Orezon Archives: inclucing the Journals, Governors' Messases anc Public Papers of Oregon. Salem: Asahel Bush, 1853.

Oregon. Laws of a General and Local Nature passed by the Legi.slative Assembly, $-1843-49$.

i. S. Census, Seventh, 1850. Washington, 1853.

U. S. Congress. House. Report of Lt. Neil M. Howison, H. Doc. 29, 30th Cong., lst sess., February 29, 1848.

U. S. Congress. House. 31st Cong., Ist sess., February 5 1850 ; May 28, 1850, Congressional Globe, 413; 1075-80.

U. S. Congress. Senate. S. Doc. 59, 32nä Cong., Ist session.

U. S. Congress. House. H. Doc. 177, 40th Cong., 2d sess., February 17,1868 .

T. S. Congress. Senate. S. Doc. 59, 4th Cong., 3d sess., October $19,1878$. 
J. S. Congress. Senate. 50th Cong., 1.st sess., Congressional Record, p. 8225.

Microfilm

"Early Life on Vancouver Island." MS. 101, Oregon Historical bociety.

Fort George Journal, Feb. 25 - July 25, 1846. MS. 540, Oregon Historical Society.

Fort Langley Journal, 1827-1830. Oregon Historical Society.

Hawail: Sandwich Islands correspondence, British Foreign office, 1842-74. Oregon Historical Society.

McLoughlin-Fraser Family papers, 1796-1857, MS. 927. Oregon Historical Society.

Oregon, Territorial Papers, U. S. Senate. National Archives.

Papers of the Provisional and Territorial Governments of Cregon, 1841-1859. Oregon Historical Society.

Records of the Russian-American Company 1802, 1817-1867. National Archives.

\section{Newspapers}

Alta California, San Francisco. May 24, 1862.

Deseret News, Salt Lake City. December 16, 1911.

Herald Republican, Salt Lake City. November 1, 1917.

Mail-Tribune, Medford, Oregon. March 22, 1967.

Oregon Srectator, Oregon City and Salem, Cregon. June 27, 1850; September 12, 1850.

Oregon Statesman, Salem, Oregon. December 27, 1853.

Salt Lake Heralö, Salt Lake City. June 20, 1896.

The Deseret Fvening News, Salt Lake City. December 22, 1894 ; irovember 14, 1896; December 19, 1903; November 1, 1917.

The Friend; Honolulu. September 4, 1844-September 1, 1865. Utah Enalirer, Salt Lake City. November 1, 1889. 
Journals and Diaries

Corney, Peter. Voyages in the Northern Pacific....

"Diary of Rev. George Henry Atkinson, D.D., 1847-1858." Ruth F. Rockwood, ed. Oregon Historical Quarterly, XXXX (March, June, September, December, 1939), 52-64, $168-88,265-83,345-62$.

"Earliest Expedition Against Puget Sound Indians." Intro. by Eva Emery Dye. Washington Historical Cuarterly: 2 (January, 1907), $16-30$.

"Extracts from the Journal of Henry W. Bigler." Wtah Historical cuarterly, 5 (April-october, 1932), 35-65, $87-112,134-160$.

Lamb, W. Kaye, ed. The Journal of Gabriel Franchère. Toronto: The Champlain Society, 1969.

Lyman H. S. "Reminiscences." Oregon Historical Quarterly, IV (September, 1903), 251-66.

McLeod, John. Journals and Correspondence from 1812 to 1844. Typescript from originals at Dominion Government Archives.

Meares, John. Voyages Made in the Years 1788 to 1780 from China to the North West Coast of America. London: J. Walter, 1790.

"Memoirs of Thomas Hopoo." The Hawaiian Journal of History, $2(1968), 42-55$.

"Menzies' California Journal." Intro. by Alice Eastwood. California Historical Society Cuarterly, II (January, $1924), 265-340$.

Minto, John. "Trom Youth to Age as an American." Oregon Historical Quarterly, IX(June, 1908), 127-72.

Ross, Alexander. The Fur Funters of the Far West; A Narrative of Adjentixes in the Oregon and Pocky Mountains. $z$ vols. London: Saith, Elder and Co., 1855 .

Simpson, Sir George. Narrative of a Journey Round the Worid, Durine the Years 1841 and 1042. 2 vols. London: Henry Colburn, 1847. 
Sutter, John A. The Diary of Joranr Augustus Sutter. Sar Francisco: Grabborn Press, 1932 .

Work, John. Fur Bnigade to the Bonaventura. San Francisco: California Fistcrical Society; 1945.

Young, F. G., ed. The Correspondence and Journals of Captain Nathaniel J. Wyeth 1831-6. Eugsne: Jniversity Press, 1899.

Articles

Anderson, Thomas M. "The Vancouver Reservation Case. A Legal Romance." Oregon Historical Quarterly, VIII (September, 1907), 219-230.

Arrington, Ieonard J. "The L.D.S. Hawalian Colony at Skull Valley." The Improvement Era, 57 (May, 1954), $314-15 ; 365-67$.

Bennett, Guy William. "Early Relations of the Sandwich Islanòs to the old Oregon Territory." Washington Historical Quorterly, IV (April, 1913), $116-126$.

Clark, Donald H. "Sawmill on the Columbia." The Beaver, Outfit 281 (June, 1950), $42-44$.

Clark, R. C. "Hawaiians in Early Oregon." Oregon Historical Quarterly, XXXV (March, 1934), 22-32.

Conrad, Agnes C. "Hawailan Registered Vessels." Hawailan Journal of History, 3 (1969), 3I-4I.

Dillon, Richard H. "Kanaka-Colonies in California." Pacific Historical Review, XXIV (February, 1955), 17-23.

"Edward Vischer's First Visit to California." Tr. and ed. by Erwin Gustau Gudae. California Historical Scciety Quarterly, 19 (September, 1940), 193-216.

"Fort Boise: From Imperial Outpost to Historic Site." Idaho Yesterdays, 6 (Epring, 1962), 14-17; 33-40.

Greer, Richard A. "Wandering Kamainas: Notes on Hawaisan Emigration Before 1848." Journal of the West, XI (April, 1967), 221-26.

Joesting, Elward and D. E. Livingston-Littie. "A Scotsman Vews Hawaii: An 3.852 Log of a Cruise of the Emily Bourne." Journal of the West, IX. (April, 1970), 196221 . 
Kemble, John Haskell. "The First Steam Vessel to Navigate San Francisco Bay." California Historical Society Quarterly, XIV (June, 1935), 143-145.

Kime, Wayne R. "Alfred Seton's Journal: A Source for Irving's Tonquin Disaster Account." Oregon Historical Quarterly, IXXI (December, 1970), 309-24.

Kittelson, David. "John Coxe: Hawaii's First Soldier of Fortune." Hawaiian Historical Review, I (January, $1965), 194-98$.

Knuth, Priscilla and Thomas Vaughan, eds. "The Round Hard of George B. Roberts, The Cowlitz Farm Journal, 184751." Oregon Historical Quarterly, LXIII (June, September, 1962), 101-175.

"Letters of A. Rotchev, last Commandant. at Fort Ross, and the Resume of the Report of the Russian-American Company after the year 1850-51." Ed. and intro. by Frederick C. Cordes. California Historical Snciety Quarterly, XXXIX (June, 1960), 97-1.16.

Schmitt, Robert C. "Population Characteristics of Hawaii, 1778-1850." Hawaiian Historical Review, I (April, $1965), 199-211$.

Taylor, Paul S. "Foundations of California Rural Scciety." California Historical Society Quarterly, XXIV (September, 1945), 193-228.

"The Sandwich Island Country and Mission." The Contributor, XVII (October, 1896), 699; 734-39.

Van Alystyne, Richard W. "International Rivalries in the Pacific Northwest." Oregon Historical Quarterly, XXXXVI (September, 1945), 185-218.

\section{Books}

Bailey, Helen Miller and Abraham P. Nasatir. Latin America: The Development of its Civilization. New Jersey: Prentice-Hall, 1960.

Berker, Burt Brown. Letters of Dr. Tohn McLoughlin wrjiten at Fort Vancouver $18<0-1832$. Portiand: Binfords \& Mort, 1948 .

Billington, Ray Alien. The Protestant Crusade 1800-1860. A Study of the origins of American Nativism. Chicago: Guadrangle Books, 1964. 
American Frontier. Third eation. New York: Macililan, 1967.

Bingharn, Hiram. A Residence of Twenty-one Years in the Sandwich Islands. Hartord, Conn.: Hezekiah Huntington, 1848 .

Blanchet, Frances Norbert. Historical Sletches of the Catholic Church in Oregon. Portland, 1878 .

Cowan, Robert Ernest. A Bibliography of the History of California and the Pacific West 1510-1906. Columbus, Ohio: Long's College Book Co., 1952.

Davidson, Gordon. The North West Company. Berkeley: Iniversity of California Press, 1918.

Glazebrook, G. P. DeT., ed. The Hargrave Correspondence. Toronto: The Champlain Society, 1938.

Gregson, Harry. A History of Victoria 1842-1970. Victoria, B.C.: Victoria Publishing Co., Lta., 1970.

Hammond, George P., ed. The Larkin Papers. Personal, Eusiness, and Official Correspondence of Thomas oliver Larkin, Merchant and United States Consul in California. I0 vols. Berkeley: University of California Press, 1951 .

Haskins, C. W. The Argonauts of California. New York: Fords, Howard \& Hulbert, 1890 .

Hittell, John. The Commerce \& Industries of the Pacific. San Francisco: A.L. Bancrcft \& Co., 1882.

Hodge, Frederick Nebb. Handbook of American Indians North of Niexico. 2 vols. Washington, D.C.: Government Printing office, 1912.

Hofstadter, Richard. The Age of Reform: Fron Bryan to F.D.R. New York: Random House, 1955.

Hudson's Bay Record Society. McLoughlin's Fort Vancouver Letters. $1825-1838,1839-1844,1844-1846.3$ vols. Iondon: Hudson's Bay Record Society, 1941 .

Hunnewel], James F. Bibliography of the Hawaiian Islands. New York: Kraus Reprint Corp., 1962. 
Hussey, John M. The History of Fort Vancouver and its Physical Structure. Tacoma: washington State Fistorical Society, 1957? .

Jessett, Thomas E., ed. Reports and Letters, 1836-1838, of Herbert Beaver. Pcrtland: Champceg Press, 1959.

Kuykendall, Ralph S. The Hawailan Kingdom 1778-1854: Foundation and Transformation. Honolulu: University of Hawai i Press, 1947.

and A. Grove Day. Hawail: A History From PoIynesian Kingdom to American State. New Jersey: Prentice-Hall, 1961.

Lind, Andrew W. Hawaii's People. Honolulu: University of Hawai Press, 1955.

Martin, William. Catalogne d'ouvrages relatifs aux iles Hawaii, 1867. Microfilmed June, 1961, by Cregon Fistorical Society from original in possession of Preston McKann, Portland.

Merk, Frederick. The Oregon Question. Essays in AngloAmerican Diplomacy and Politics. Cambridge: Farvard University Press, 1967.

Morgan, Dale I. and George P. Hammond, eds. A Guide to the Manuscript Collections of the Bancroft Library. Berikeley: Inniversity of California Press, 1963.

Oxun, S. B. The Russian-American Company. Cambridge: Harvard University Press, 1951.

Painter, Sidney. A History of the Middle Ages 284-1500. New York: Alfred A. Knopf, 1961.

Paulin, Charles 0 , and Frederic L. Paxson. Guicie to the Materials in London Archives for the History of the Wited States since 1783. Carnegie Irstitution: Washington, D. C., 1914.

Paxton, John, ed. The Statesman's Yearbook 1970-1971. lo7th edition. New York: Macmillan, 1970.

Guatfe, Milo M., ed. Advertures of the First Settlers on the oregon or Columbia River. Chicago: Lakeside Fress, IVR3.

Scuié, Frani, John H. Gihon and James Nisbet. The Annals of San Francisco. New York: Appleton, 1854 . 
Statistical Annals of the Tnited states of America. Pinladelphia: Thomas Dobson \& Son, 1818.

Tate, Merze. The United States and the Hawailan Kingdom. A Political History. New Haven: Yale University Press, 1965.

Taylor, Albert Pierce. Sesquicentenniel Celebration of Captain Cook's Discovery of Hawaii $(1778-1928)$. Honolulu: Archives of Elawaii Ccmission, 1929 .

The Voyages of Captain James Cook Round the World. 7 vols. London: Richard Phillips, 1809.

Woodward, C. Vann. The Strange Career of Jim Crow. Second revised edition. New York: Oxford University Press, 1966.

Thesis

Atkin, Dennis H. "A History of Iosepa; the Utah Polynesian Colony." Unpublished thesis, Brikham Young University, 1958.

Reviews

Cowan, Robert E. Review of San Francisco Town Journal 18471848. California Historical Society Quarterly, $V$ (December, 1926), 405-07. 